$$
\text { UNIVERSIDADE DE SÃO PAULO }
$$

FACULDADE DE FILOSOFIA, LETRAS E CIÊNCIAS HUMANAS DEPARTAMENTO DE LETRAS CLÁSSICAS E VERNÁCULAS PROGRAMA DE PÓS-GRADUAÇÃO EM FILOLOGIA E LIINGUA PORTUGUESA

\title{
O discurso da mulher esclarecida na produção jornalística de Clarice Lispector: \\ o caso Feira de Utilidades
}




$$
\text { UNIVERSIDADE DE SÃO PAULO }
$$

\title{
FACULDADE DE FILOSOFIA, LETRAS E CIÊNCIAS HUMANAS DEPARTAMENTO DE LETRAS CLÁSSICAS E VERNÁCULAS PROGRAMA DE PÓS-GRADUAÇÃO EM FILOLOGIA E LÍNGUA PORTUGUESA
}

\section{O discurso da mulher esclarecida na produção jornalística de Clarice Lispector: \\ o caso Feira de Utilidades}

Luiz André Neves de Brito

\begin{abstract}
Dissertação apresentada ao Programa de PósGraduação em Filologia e Língua Portuguesa, do Departamento de Letras Clássicas e Vernáculas da Faculdade de Filosofia, Letras e Ciências Humanas da Universidade de São Paulo, para obtenção do título de Mestre em Letras.
\end{abstract}

Orientador: Profa. Dra. Helena H. Nagamine Brandão 


\section{Banca examinadora}

Profa. Dra. Helena Hathsue Nagamine Brandão (FFLCH/USP) - orientadora Profa. Dra. Sheila Vieira de Camargo Grillo (FFLCH/USP

Prof. Dr. Sírio Possenti (IEL/UNICAMP) 
A minhas avós, matrizes deste trabalho. 


\section{A Mulher e a Casa}

Tua sedução é menos de mulher do que de casa: pois vem de como é por dentro ou por detrás da fachada.

Mesmo quando ela possui tua plácida elegância, esse teu reboco claro, riso franco de varandas,

uma casa não é nunca só para ser contemplada; melhor: somente por dentro é possível contemplá-la.

Seduz pelo que é dentro, ou será, quando se abra; pelo que pode ser dentro de suas paredes fechadas;

pelo que dentro fizeram com seus vazios, com nada; pelos espaços de dentro, não pelo que dentro guarda;

pelos espaços de dentro: seus recintos, suas áreas, organizando-se dentro em corredores e salas,

os quais sugerindo ao homem estâncias aconchegadas, paredes bem revestidas ou recessos bons de cavas,

exercem sobre esse homem efeito igual ao que causas a vontade de corrê-la por dentro, de visitá-la. 


\section{Agradecimentos}

- à minha família, pelo carinho e pelo apoio incondicional;

- a Helena H. Nagamine Brandão, minha orientadora “esclarecida”, por acreditar em meu trabalho, por pontuar as minhas escolhas com sabedoria e precisão, e sobretudo pela paciência;

- a Sheila Vieira de Carvalho Grillo e Sírio Possenti, pelas instigantes sugestões e críticas durante o exame de qualificação, as quais espero ter sabido aproveitar;

- a Zilda Gaspar Oliveira de Aquino, pelos incentivos durante o PAE e, principalmente, pelo carinho e pela amizade;

- aos meus amigos, sempre fiéis e companheiros, especialmente a Oriana Fulaneti, amiga admirável, sempre disposta a dialogar sobre as questões teóricas envolvidas neste trabalho;

- aos meus confrades de texto, André, Helena e Luciana, pela grande amizade “no” e "fora" dos textos;

- aos funcionários da Biblioteca Nacional e do Instituto Moreira Sales do Rio de Janeiro, por se mostrarem sempre dispostos a me atender e a me ajudar na coleta do arquivo desta pesquisa;

- à CAPES, pela concessão da bolsa de pesquisador. 


\section{Resumo}

Nesta dissertação, o objetivo central é investigar, de uma perspectiva discursiva da Análise de Discurso de linha francesa - AD, as condições de produção do discurso da mulher esclarecida no interior de Feira de utilidades, coluna feminina publicada entre agosto de 1959 e fevereiro de 1961, escrita por Clarice Lispector com o pseudônimo de Helen Palmer. Observamos, também, como a linguagem reflete e refrata as condições de produção em sua materialização, nos enunciados, as marcas das formações discursivas de uma época. Ao evidenciar essas marcas, o discurso constrói uma "maneira de dizer" - um ethos que visa a sua individualização.

Partindo da hipótese de que a coluna feminina, por ser um gênero discursivo com aspecto mais autoral, apresenta uma cenografia mais movediça, centramos nosso percurso teórico na problemática dos gêneros discursivos. Partindo dos pressupostos teórico-metodológicos de Maingueneau (1984; 1987; 1991; 1998; 2004), segundo o qual o gênero, enquanto prática discursiva, deve ser abordado como um ritual convencionado socialmente e submetido a um critério de êxito; essa etapa procura analisar o modo de genericidade da coluna, ou seja, observar a relação entre cena genérica e cenografia.

Respondida a questão de como se dá o funcionamento do gênero coluna feminina nas páginas do jornal Correio da Manhã, passamos à segunda etapa da análise, que tem como objetivo responder à seguinte questão: Como Feira de Utilidades, no processo de sua constituição, legitima a discursividade da mulher esclarecida? Para realizar tal análise, mobilizamos o conceito de ethos proposto por Maingueneau.

Palavras-chave: análise do discurso; imprensa feminina; gêneros discursivos; ethos. 


\begin{abstract}
This dissertation examines, under the rubric of French Discourse Analysis, how the discourse of the clever woman was produced in Feira de utilidades - female column published from August 1959 to February 1961 by Clarice Lispector who wrote under a pseudonym 'Helen Palmer'. We also analyzed how the language reflects and refracts on the discourse the marks of a discursive formation of a specific age. Because of these marks, the discourse builds an ethos in order to individualize its existence.

From the hypothesis that the female column is a kind of a discursive genre which has an authorial aspect (mobile scenery), we focused our theoretical way on the problematic of the discursive genre. On the basis of the concepts derived from the studies of Dominique Maingueneau (1984; 1987; 1991; 1998; 2004), genre is a discursive practice which must be seen as a conventional social ritual under a criteria of existence; this part of this dissertation analyze the relation between generic scene and scenery.

After answering this question of how the genre female column works on Correio da Manhã, we moved into our second question that was to analyze how Feira de utilidades, on the process of its constitution, legitimize the discourse of the clever woman. In order to find an answer for this question, we mobilized the concept of ethos studied by Maingueneau.
\end{abstract}

Key-words: Discourse analysis; female press; discursive genre; Ethos. 


\section{Sumário}

Apresentação ............................................................................................ 10

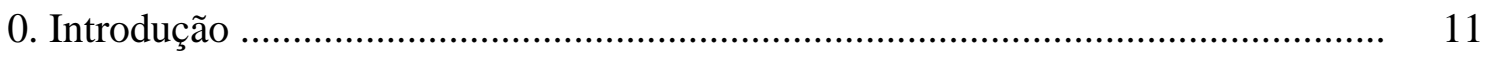

0.1 Perto de um coração jornalista: delimitação de um corpus ................................. 12

0.2 A descoberta do mundo: justificativa do tema ................................................ 13

$0.3 \mathrm{O}$ gênero sitiado: percursos teóricos e metodológicos ...................................... 15

0.4 A dissertação e seus $\operatorname{laços~............................................................................~} 18$

1. Gêneros do discurso: construção e reconfiguração na AD ................................. 20

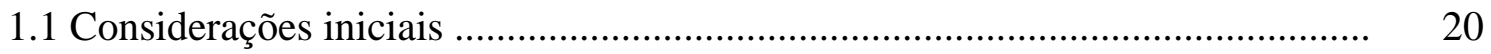

1.2 Gêneros discursivos: as não coincidências do dizer... uma problemática!........... 21

1.3 Bakhtin: observações sobre a teoria dos gêneros .................................................. 26

1.4 AD e a problemática dos gêneros ............................................................... 30

2. Em “cena” Feira de utilidades: do discurso à prática discursiva ......................... 35

2.1 Considerações iniciais ........................................................................................ 35

2.2 Feira de utilidades: em “cena” as coerções ...................................................... 37

2.3 Feira de utilidades: em “cena” o mídium ........................................................... 47

2.4 Análise de uma coluna em “cena”: da cena genérica à cenografia ..................... 51

a) Sobre o enquadramento espaço-temporal e o peritexto ................................ 53

b) Finalidade e estatuto dos participantes ...................................................... 54

c) Organização textual ................................................................................ 54

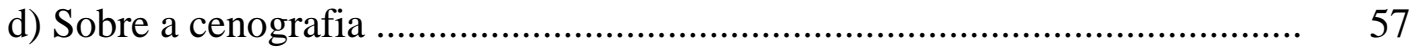

3. Feira de utilidades: a mulher esclarecida em “cena” .............................................. 70

3.1 Considerações iniciais ................................................................................. $\quad 70$

3.2 A mulher esclarecida em “cena”: o vínculo conjugal ........................................ 72

3.3 A mulher esclarecida em “cena”: a representação do corpo belo, jovem e 80 saudável

3.4 A mulher esclarecida: em “cena” a negação .................................................. 96

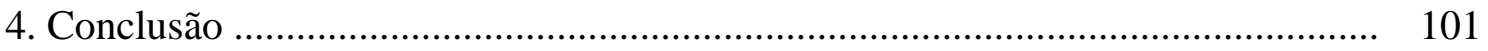

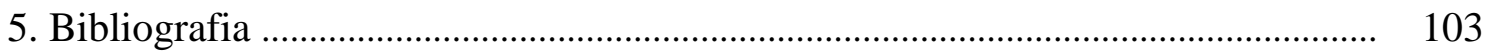




\section{Apresentação}

“Tudo no mundo começa com sim”

Clarice Lispector, A hora da estrela

Retomando as palavras iniciais de Foucault em A ordem do discurso (2002b), “Gostaria de me insinuar sub-repticiamente no discurso que devo pronunciar (...), e (...) ao invés de tomar a palavra, gostaria de ser envolvido por ela e levado bem além de todo começo possível (...) bastaria então que eu encadeasse, prosseguisse a frase (...) em seus interstícios”. É esse interstício da frase, ou melhor, do enunciado que desejo correr por dentro, visitar. Digo enunciado e não frase por partir de pressupostos teóricos da Análise do Discurso (doravante $\mathrm{AD}$ ) para realizar uma análise pertinente que possibilite abordar o discurso no “fervor” de seu acontecimento. Buscando uma união entre o plano de enunciado e o da enunciação, a pesquisa é enveredada por um caminho/sentido entre muitos possíveis, pois os caminhos/sentidos jamais podem ser estáveis, concluídos, acabados de uma vez por todas, ou seja, “não existe nada absolutamente morto: cada sentido terá sua festa de renovação” (Bakhtin). Sejam, então, bem-vindos à festa.

A minha festa de renovação surgiu a partir do momento em que uma teoria (AD) disse sim a uma escritora (Clarice Lispector) e nasceu minha pesquisa. Mas antes de penetrar nos interstícios da pesquisa, gostaria de falar um pouco mais sobre essa escritora e apresentar uma posição-sujeito ocupada por Lispector, da qual certamente poucos têm conhecimento.

Falar de Clarice... é um dar a mão a uma paixão, ao "inexpressivo” que sempre foi a sua “busca cega e secreta”.... é falar da sua matéria primordial, a palavra nevrálgica, uma palavra que pulsa a cada instante, uma palavra crua, uma palavra que arde como água viva... é falar de um universo feminino povoado por Anas, G.Hs., Macabeas, Loris, Lucrécias, Virginias etc. É a essa Clarice que nossa memória nos remete, a Clarice dos contos e dos romances. Quero convidá-los a conhecer uma Clarice jornalista, pois poucos sabem da sua vasta contribuição à nossa imprensa escrita. 
(0)

\section{Introdução}

“A mulher mais elegante não me interessa. Há problemas mais sérios do que a moda, Individuais e não individuais"

Clarice Lispector, De corpo inteiro

No século XIX, com a vinda de D. João VI para o Brasil, dá-se início à imprensa feminina brasileira, cujo conteúdo era basicamente moda e literatura, além de refletir sobre as transformações pelas quais passava a sociedade brasileira da época.

Copiando as tendências européias, em 1827, lançava-se no Rio de Janeiro o primeiro periódico intitulado $O$ Espelho Diamantino, cujos temas eram política, literatura, belas-artes, teatro e moda. Não se restringindo ao cenário carioca, as publicações de periódicos femininos espalharam-se pelo país.

Segundo Buitoni (1981), nos periódicos do século XIX, encontravam-se duas representações bem definidas do papel feminino na sociedade: uma tradicional que não permite liberdade fora do lar e outra progressista que defende os diretos da mulher dando grande ênfase à educação. Dando continuidade a esse percurso, a pesquisadora analisa por várias décadas do século XX (1900 a 1970) na busca de descrever as representações femininas nos periódicos de cada época. Entre essas formas de representação, destacamos a dos anos 50 que serviu de suporte para este trabalho. Para a pesquisadora, validava-se o estereótipo da mulher jovem, esperta o bastante para não ofuscar ou cansar o namorado. A beleza aparece como atributo necessário, como se fosse algo natural da mulher. Os conselhos circulam em torno de um enunciado-base: tem que ser encantadora. Além da beleza, a ideologia da imprensa voltada ao público feminino centrava a felicidade suprema no amor e no lar.

Nesse cenário, no campo da imprensa feminina, várias revistas e suplementos circulavam, entre eles: a coluna Feira de utilidades assinada por Helen Palmer (pseudônimo de Clarice Lispector). 


\subsection{Perto de um coração jornalista: delimitações de um corpus}

Clarice escreveu para vários jornais e revistas, dentre eles: Pan (1940, Rio de Janeiro); Vamos Ler (1940/1941, Rio de Janeiro); Folha de Minas (1944, Belo Horizonte); Comício (1952, Rio de Janeiro); Correio da Manhã (1959/1961, Rio de Janeiro); Diário da Noite (1960/1961, Rio de Janeiro); Senhor (1959/1964, Rio de Janeiro); Manchete (1968/1969, Rio de Janeiro); Fatos e Fotos (1976/1977, Brasília); Jornal do Brasil (1967/1973, Rio de Janeiro). Na imprensa escrita, seu trabalho foi marcado pela heterogeneidade das funções que desempenhou (colaborando com crônicas, entrevistas, artigos para páginas/colunas femininas), executando tarefas que, a priori, não se identificavam com o fazer do texto literário.

Dentre as funções desempenhadas, uma me chamou a atenção... uma Clarice que escrevia artigos para páginas/colunas femininas de três jornais: Comício, Correio da Manhã e Diário da Noite. Um fato interessante era que, ao confeccionar tais páginas, Clarice as assinava com os seguintes pseudônimos, respectivamente: Teresa Quadros, Helen Palmer e Ilka Soares. Por que esses artigos das páginas/colunas femininas?

A imprensa escrita é um espaço simbólico das representações coletivas, um veiculador de ideologia e de investimentos de valor, fundamentado no conhecimento de mundo. No que toca à questão da mulher, como se dá o relacionamento com essa imprensa escrita dos anos 50? Ou seja, como a mulher é vista pela imprensa escrita dos anos dourados e por ela representada?

Mas para verificar essa representação feminina nas páginas/colunas descritas acima, é preciso observar como se dá o funcionamento dessa prática discursiva que ocupava um considerável espaço nos três jornais. Fato interessante, pois o espaço discursivo delimitado pela imprensa feminina dos anos 50; não se limitava apenas às revistas, mas também aos jornais ${ }^{1}$.

Para tentar observar esse funcionamento, tinha à minha frente três periódicos diferentes: Comício, Correio da Manhã e Diário da Noite. O segundo passo seria realizar o árduo trabalho da leitura na busca de uma delimitação do corpus. Inicialmente

\footnotetext{
1 Alguns jornais que circulavam no Rio apresentavam suplementos femininos: o Jornal do Brasil publicava um suplemento intitulado Revista de Domingo; o Globo tinha um suplemento diário; o Diário da Noite publicava, também, diariamente um suplemento intitulado Só para mulheres. As discursividades desses suplementos estavam relacionadas a segredos culinários, a conselhos para dona-de-casa, a comportamento feminino e, principalmente, a conselhos de beleza e de moda.
} 
pensava em analisar os três periódicos e depreender o elo mantido entre eles, mas um texto publicado no Correio da Manhã me chamou a atenção e todo o percurso foi alterado. Esse texto intitulado uma mulher esclarecida me levou a outras veredas e meu interesse passou a ser a análise do discurso da mulher esclarecida. Uma vez escolhido o periódico com o qual trabalharia, construí um arquivo composto por noventa e seis colunas publicadas entre agosto de 1959 e fevereiro de 1961.

Partindo de colunas do Correio da Manhã que se referem a um estilo esclarecido de ser da mulher inserida na sociedade burguesa dos anos dourados, nosso segundo passo seria delimitar o corpus desta pesquisa. Tomando como base de trabalho um gênero de discurso - a coluna feminina, o corpus foi construído por formulações inseridas na coluna que pudessem mostrar a estabilidade de uma cena genérica e as constâncias do discurso da mulher esclarecida.

\subsection{A descoberta do mundo: justificativa do tema}

Resumindo o que foi dito nos parágrafos anteriores, é meu objetivo central analisar uma coluna feminina publicada por Clarice Lispector entre agosto de 1959 e fevereiro de 1960. Partindo de formulações textuais dessas colunas, procuro salientar as estratégias utilizadas pela escritora para se comunicar com a leitora cujo estereótipo era o da mulher doméstica, consumidora e sedutora. Pretendo, assim, compreender como essas colunas produzem sentido e quais os seus efeitos, observando como a linguagem reflete e refrata as condições de produção, trazendo em sua materialização, nos enunciados, as marcas das formações sociais, ideológicas e discursivas de uma época, ou seja, numa relação entre a linguagem e a historicidade.

Penetrar nos interstícios da imprensa feminina é procurar observar o espaço simbólico das representações coletivas, aceitando que o estereótipo está nela presente através das categorias que fundamentam o conhecimento de mundo. Nesse sentido, a imprensa feminina, veiculadora de ideologia, funciona como um campo discursivo constituído por discursos heterogêneos sobre como as mulheres se constituem como sujeito moral na sociedade, em especial, na sociedade burguesa dos anos 50. 
No interior desse campo discursivo, nossa pesquisa volta seus olhares para uma prática discursiva - a coluna feminina - procurando observar as articulações sociais, econômicas e culturais que estão implícitas em sua estruturação. Segundo Buitoni (1981) é preciso perceber o que essa imprensa representa no mundo, jamais a resumindo a receitas culinárias e contos de amor, pois suas funções não são transparentes, e não visam apenas a conselhos práticos ou lazer. Assim, para Buitoni, no espelho da imprensa feminina, as imagens e as verdades são muitas.

Por isso, escolhemos o tema da mulher esclarecida cuja discursividade aponta para um deslocamento importante no espaço ocupado pela mulher dona-de-casa, mãe e esposa. A partir da leitura dos vários textos que compõem a coluna, podemos depreender como se comporta a mulher esclarecida dos "anos dourados" que, freqüentando Universidades, procura estar a par dos acontecimentos libertando-se dos falsos tabus que faziam dela um ser inferior e eternamente submisso.

Mas, se por um lado, a discursividade de Feira de utilidades constrói a imagem da mulher que ocupa uma nova posição sujeito no seio da sociedade burguesa; por outro, a discursividade de Feira de utilidades mostra um enunciador conservador cujo princípio é limitar a mulher ao espaço privado do lar. Nesse jogo entre o novo e o conservador, Feira de utilidades vai construindo sua discursividade e legitimando seu espaço na imprensa feminina. Vejo, então, esse discurso operando uma redefinição discursiva do espaço ocupado pela mulher burguesa. Essa redefinição ocorre justamente na incorporação do atributivo esclarecida.

O discurso da mulher esclarecida materializa em suas formulações o redimensionamento das práticas sociais da mulher burguesa numa época em que se observava um aumento das possibilidades educacionais e profissionais para a mulher. Sendo a imprensa feminina um espelho dessas práticas, Feira de utilidades não deixa de enfocar esses acontecimentos. 


\subsection{O gênero sitiado: percursos teóricos e metodológicos}

Retomando o que já foi mencionado, a partir da perspectiva da Análise do Discurso, o nosso objetivo central é investigar a produção jornalística de Clarice Lispector, observando como a linguagem reflete e refrata as condições de produção em sua materialização, nos enunciados, e as marcas das formações sociais, ideológicas e discursivas de uma época. Ao evidenciar essas marcas, o discurso constrói uma “maneira de dizer”, criando um ethos que visa à sua individualização.

Levando em consideração o ethos conselheiro como o tom constitutivo da coluna, decidimos observar como o enunciador dá corporalidade ao discurso da mulher esclarecida em Feira de utilidades. Essas considerações sobre o ethos devem ser analisadas em estreita ligação com a noção de gêneros do discurso, pois segundo Maingueneau (2005: 71) “o simples fato de que um texto pertence a um gênero de discurso ou a um certo posicionamento ideológico induz expectativas em matéria de ethos”. Partimos, então, da hipótese de que a coluna feminina, por ser um gênero do discurso com aspecto mais autoral, apresenta uma cenografia mais movediça. Frente a esse quadro, esta pesquisa procura responder às seguintes questões:

1. Qual o modo de funcionamento do gênero coluna feminina no discurso jornalístico dos anos 50 ?

2. Como Feira de utilidades, no processo de sua constituição, legitima a discursividade da mulher esclarecida?

Para responder a essas questões, retomamos a discussão dos gêneros discursivos, quadro teórico polêmico nos estudos da linguagem. Para mostrar o caráter polêmico desses estudos, construímos um breve quadro epistemológico, centrado em duas grandes correntes: uma voltada para os textos, justificando a denominação 'gêneros de texto’, e outra para as condições de produção do discurso, justificando a denominação 'gêneros do discurso'. 
No território da $\mathrm{AD}$, descrevemos um quadro epistemológico entre as reflexões de Pêcheux e de Maingueneau. Para Pêcheux, que se filia ao pensamento de Althusser, o cerne das questões era marcado pelos conceitos de formação discursiva e formação ideológica. E nessa perspectiva, as questões sobre os gêneros de discurso ocupavam uma posição marginal, tal como mostraremos no capítulo gêneros do discurso: construção e reconfiguração na $A D$.

Percorrendo a obra de Maingueneau, veremos como essa questão se apresenta em Gênese dos discursos (2005), pois de forma incipiente os gêneros são abordados nos capítulos 3 e 5, em que o autor trata, respectivamente, da semântica global e do conceito de prática discursiva. Segundo o estudioso francês, “o discurso não deve ser pensado apenas como um conjunto de textos, mas como uma prática discursiva” (p.23). Por isso, pensar em uma prática discursiva é procurar saber as condições de emprego dos textos do discurso, isto é, observar a relação entre a produção dos textos e o consumo destes. Daí a afirmação de que “o 'modo de difusão’ caminha paralelamente com o modo de consumo do discurso, isto é, com o que se faz dos textos, como eles são lidos, manipulados” (p. 141).

Ao abordar essa relação entre modo de difusão e modo de consumo, as reflexões de Maingueneau se encaminham para uma problemática dos gêneros. Nesse percurso, o autor se propõe a discutir as condições de utilização dos textos e não simplesmente o seu estatuto formal.

Em sua obra, veremos o quanto essa questão passa a ocupar o cerne da prática da AD. O texto diversidade dos gêneros do discurso ${ }^{2}$ mostra brevemente a evolução dessa problemática para o autor. Nesse texto, Maingueneau expõe sucintamente os critérios tipológicos para o estudo dos gêneros, afirmando que, "no âmbito da Análise do discurso, a categoria gênero de discurso é mais comumente definida a partir de critérios situacionais” (2004: 45). Assim, a finalidade reconhecida, o estatuto dos participantes, a legitimidade espaço temporal, o médium e a organização textual de um gênero são parâmetros para sua caracterização.

\footnotetext{
${ }^{2}$ In: MACHADO, I. L \& MELLO, R. (orgs) Gêneros: reflexões em análise do discurso. Belo Horizonte: NAD/FALE/UFMG, 2004.
} 
Essa caracterização leva à distinção de dois regimes de genericidade: os gêneros conversacionais e os gêneros instituídos. Em nossa pesquisa, assim como Maingueneau, nos debruçamos sobre um gênero instituído coluna feminina, cujas restrições semânticas e materializações dos enunciados são delimitadas pelo ambiente institucional. Conforme Brandão (1997: 142),

há como que uma espécie de rarefação dos enunciados que é ditada pelo gênero discursivo em que eles se (re)inscrevem. É o gênero discursivo que organiza os seus elementos, que os reordena internamente de acordo com suas especificidades.

Diante desse quadro, retomo um questionamento foucaultiano: como aparece um determinado enunciado, e não outro em seu lugar? Frente a essa questão, procuro observar como o gênero coluna feminina materializa um acontecimento discursivo, tendo em vista certas especificidades que decorrem da relação estabelecida entre a cena genérica e a cenografia.

Se para Bakhtin (2003: 265) "todo estilo está indissoluvelmente ligado (...) aos

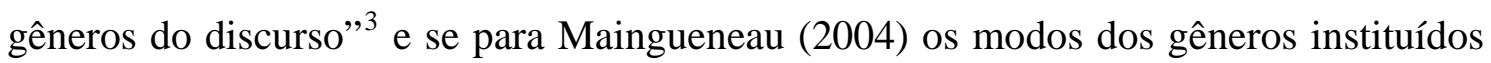
se distinguem "de acordo com a relação que se estabelece entre o que chamamos cena genérica e cenografia”, levanto, então, a hipótese de que uma das questões sobre estilo nos gêneros instituídos se dá na relação, justamente, entre a cena genérica e a cenografia. Para abordar essa questão do estilo, gostaria de retomar uma passagem de Os gêneros do discurso:

O estilo é indissociável de determinadas unidades temáticas e - o que é de especial importância - de determinadas unidades composicionais: de determinados tipos de construção do conjunto, de tipos do seu acabamento, de tipos de relação do falante com outros participantes da comunicação discursiva - com os ouvintes, os leitores, os parceiros, o discurso do outro, etc. (BAKHTIN, 2003: 266)

\footnotetext{
${ }^{3}$ BAKHTIN, Mikhail (2003). Os gêneros do discurso. In: Estética da criação verbal. Trad.Paulo Bezerra. São Paulo: Martins fontes, p. 261-306. (Segundo Paulo Bezerra, o trabalho foi escrito entre 1952 e 1953 em Sarank; os fragmentos foram publicados pela revista Estudo literário, 1978).
} 
Tendo como pressuposto que o discurso é constitutivamente heterogêneo, pois à medida que "eu" mostro o lugar do "outro" no meu discurso, "eu" me mostro, me posiciono, observamos, no discurso da mulher esclarecida, como a questão da alteridade se manifesta no fio do discurso de forma explícita e implícita.

Essa questão da alteridade nos leva a inquirir como todo discurso se constrói na relação com outros discursos, isto é, como os sujeitos e os sentidos se movimentam, fazem seus percursos e se significam entre o já-dito e o a se dizer na relação. Nesse percurso, o sujeito precisa negociar o que vai ser mantido e o que será refutado para que se possa afirmar o “um”. Para mostrar essa afirmação do “um”, mostraremos como a noção de ethos contribui para delimitar as posições assumidas.

Um fato interessante nos chamou a atenção, pois ao depreendermos o discurso da mulher esclarecida na coluna Feira de utilidades, vimos a ocorrência freqüente de uma forma explícita de heterogeneidade: o “não” polêmico.

Vimos, também, no curso da pesquisa, que seria necessário fundamentar as questões femininas e masculinas, que fundam o discurso sob análise, em alguma teoria do gênero (gender). Para compreender as relações de poder que se estabelecem socialmente entre homens e mulheres, estabelecemos pontes com as reflexões de Simone de Beauvoir (O segundo sexo, 1949), de Michel Foucault (História da sexualidade III: os cuidados de si, 1984) e de Pierre Bourdieu (A dominação masculina, 2003).

\subsection{A dissertação e seus laços}

Tendo em vista os objetivos e as questões formuladas, as hipóteses levantadas e os pressupostos teórico-metodológicos, os capítulos da dissertação foram desenvolvidos da seguinte forma:

No primeiro capítulo, tendo como pressuposto a noção de cena da enunciação, abordamos a questão central da nossa pesquisa, a problemática dos gêneros do discurso. Procuramos traçar as balizas 
teóricas que marcam a complexidade e o avanço das discussões acerca dessa problemática nos territórios da $\mathrm{AD}$;

No segundo capítulo, limitamos a análise ao gênero coluna feminina. Para tal, selecionamos uma coluna a fim de mostrar como a trama textual-discursiva é construída. E dessa trama, tecemos observações sobre a cenografia que, consoante Maingueneau (1999b), é imposta não pelo gênero, mas construída pelo próprio texto;

No terceiro capítulo, a fim de contextualizar a coluna Feira de utilidades, visamos a descrever como o tema da mulher esclarecida está atrelado aos dois temas centrais da coluna: a mulher e o lar e a mulher e os cuidados de beleza. Para exemplificar o que será dito ao longo desse capítulo, selecionamos enunciados presentes nos diversos gêneros textuais que compõem a coluna. Os excertos, então, nos permitiram mostrar como o modo de enunciar da prática discursiva em questão é validado. Para traçar comentários sobre essa discursividade, nos apoiamos sobre a noção de ethos;

Nas observações finais, sintetizamos as conclusões possibilitadas ao final de nosso percurso, explicitando as condições centrais de nosso trabalho, assim como algumas pistas que se abrem para novas reflexões. 
(1)

\title{
Gêneros do discurso: construção e reconfiguração na AD
}

\author{
“Crônica é um relato? É uma \\ conversa? É um resumo de um estado de \\ espírito? Não sei, pois antes de começar a \\ escrever para o Jornal do Brasil, eu só tinha \\ escrito romances e contos " \\ (Clarice Lispector, Ser cronista. \\ In: A descoberta do mundo).
}

\subsection{Considerações iniciais}

Imagino que esta seja uma boa epígrafe para dar início a esse capítulo, pois a pergunta que Clarice se faz, vários teóricos da linguagem também a fazem ao refletirem sobre o gênero. Não é só Clarice que encontra dificuldade em definir, em conceituar seu objeto, muitos lingüistas encontram a mesma dificuldade ao procurarem classificar os gêneros discursivos que os cercam.

Se perguntássemos a um escritor "o que é conto?” ou a um advogado "o que é uma petição?”, certamente eles teriam dificuldade em saber conceituar o seu objeto de trabalho. Agora, pergunto-me: "qual a definição de gênero discursivo?”. Sem dúvida, para o lingüista, essa é uma pergunta que não se cala e que instiga a nossa pesquisa.

Neste capítulo, em linhas gerais, procuramos traçar as balizas teóricas que marcam a complexidade e o avanço das discussões acerca da problemática dos gêneros do discurso. A complexidade desse tema se deve à diversidade dos pontos de vista que cercam duas orientações principais: uma voltada para os textos, justificando a denominação 'gêneros de texto', e outra para as condições de produção do discurso, justificando a denominação 'gêneros do discurso'. Diante dessa problemática, as reflexões presentes nesta dissertação se propõem a responder como se dá a comunhão do plano textual (a materialidade lingüística) com o plano discursivo. Para apreender essa questão que constitui o eixo da nossa análise, apoiamo-nos em um mecanismo metodológico que se funda sobre a noção de "cena de enunciação" proposta por Dominique Maingueneau. 


\title{
1.2 Gêneros discursivos: as não-coincidências do dizer... uma problemática!
}

\author{
É notório entre os lingüistas que a problemática dos gêneros tem ocupado um
} espaço considerável nos estudos sobre a linguagem desde os anos 90 do século XX. Diante dessa crescente discussão, várias são as concepções de gênero que têm circulado, gerando um cenário complexo constituído de várias vozes. Para exemplificar ${ }^{4}$, brevemente, esse cenário, podemos citar: os estudos de Adam $^{5}$, que se inserem no campo da lingüística textual ${ }^{6}$, definindo o texto como uma estrutura seqüencial heterogênea ${ }^{7}$; a oposição gêneros de texto ${ }^{8}$ e tipos de discurso ${ }^{9}$ proposta por Bronckart

\footnotetext{
${ }^{4}$ Tomamos emprestado o quadro descrito no Dicionário de Análise do Discurso (2004: 251).

${ }^{5}$ Partindo de uma perspectiva lingüística, Adam $(1991,1999,2001)$ se propõe a descrever a organização da textualidade com base na tipologia de seqüência. A fim de justificar seu posicionamento frente às questões textuais, Adam deixa claro o quanto suas reflexões estão próximas das de Bakhtin em "a problemática do texto" (In: Estética da criação verbal). Para o lingüista francês, é somente o plano da organização seqüencial da textualidade que pode ser considerado como uma base tipológica. Essa tipologia textual foi fundada tomando como base os "tipos relativamente estáveis de enunciados" e as regularidades composicionais de que fala Bakhtin. Isto é, as estruturas seqüenciais são o que Bakhtin chama de heterogeneidade composicional dos enunciados. Pois, para Adam, definir um texto como uma estrutura seqüencial permite abordar tal heterogeneidade composicional. E a heterogeneidade é um dado que o lingüista não pode ignorar. Isso significa dizer que a seqüência é a unidade constituinte do texto, e esta, por sua vez, é constituída por proposições macro e micro. Concluindo, conforme Adam, nessa perspectiva "o texto deve ser visto como uma estrutura hierárquica complexa abrangendo $n$ seqüências elípticas ou completas - de mesmo tipo ou tipo diferente" (1991: 16).

${ }^{6}$ Com relação a esse campo, Adam (1999: 17) o descreve da seguinte forma: "L’hétérogénéité et la complexité de son objet ont eu progressivement raison des ambitions structuralistes initiales de la linguistique textuelle: élaborer, d'une part, une grammaire de texte et présenter, d'autre part, des typologies de textes. Ce doublé deuil étant aujourd'hui fait, la linguistique textuelle doit prioritairement se situer par rapport à deux domaines disciplinaires proches: l'analyse de discours et la pragmatique”. Este trecho me chama a atenção, justamente, para ratificar que uma análise dos gêneros do discurso é um ponto de confluência de três campos teóricos: a lingüística textual, a pragmática e a análise do discurso. Adam, em seus estudos mais recentes, expõe como se dá o posicionamento da lingüística textual na Análise do Discurso. Para abordar essa problemática, o autor descreve um campo complexo da lingüística textual entre práticas discursivas descendentes e práticas textuais ascendentes. No seu dizer (1999: 35), "la linguistique textuelle a pour tache de décrire les principes ascendants qui régissent les agencements complexes mais non anarchiques de propositions au sein du système d'une unité TEXTE aux réalisations toujours singulières. L'analyse du discours - pour moi analyse des pratiques discursives qui renonce à traiter comme identiques les discours judiciaire, religieux, politique, publicitaire, journalistique, universitaire, etc. - s'attarde quant à elle prioritairement sur la description de régulations descendantes que les situations d'interaction, les langue et les genres imposent aux composantes de la textualité".

${ }^{7}$ Adam propõe a classificação em cinco seqüências: narrativa, descritiva, argumentativa, explicativa e dialogal-conversacional. Segundo o autor, ao observamos no texto a combinação dessas seqüências veremos o quanto ela é complexa, podendo apresentar "várias modalidades (encaixamento hierárquico, mesclas, etc.) e é da diversidade das sequiências e da diversidade de suas modalidades de articulação que decorre a heterogeneidade composicional da maioria dos textos" (BRONCKART, 2003: 219).

8 "Os textos [na escala sócio-histórica] são produtos da atividade de linguagem em funcionamento permanente nas formações sociais: em função de seus objetivos, interesses e questões específicas, essas formações elaboram diferentes espécies de textos, que apresentam características relativamente estáveis (justificando-se que sejam chamadas de gêneros de texto)" (2003: 137).

${ }^{9}$ Segundo Bronckart, a expressão tipo de discurso designa os elementos constitutivos da heterogeneidade textual (línguas, linguagens e estilos).
} 
cuja proposição teórica deriva de uma psicologia da linguagem orientada pelos princípios epistemológicos do interacionismo social; as categorias gênero situacional (referem-se às condições do contrato global ou de gêneros textuais relativos ao conjunto dos textos reunidos em nome de seu pertencimento a um mesmo contrato) e sub-gênero (variantes encaixadas em um contrato global) de Charaudeau ${ }^{10}$, cuja proposição parte de restrições situacionais e discursivas; por último, Maingueneau ${ }^{11}$ (teórico sobre o qual nos apoiaremos) que distingue tipo de discurso de gênero de discurso.

Esse breve cenário descreve um contexto atual, mas, se tomarmos como base um contexto epistemológico mais amplo, veremos que a problemática do gênero ressurge a partir do questionamento da lingüística geral saussuriana, pois, segundo Bouquet (2004), nos anos $60^{12}$, as contribuições de Benveniste e Weinrich à semântica do tempo verbal representam certamente um avanço crucial para uma lingüística do gênero ${ }^{13}$. E como embrião de uma teoria do gênero, podemos citar as funções da linguagem definidas por Jakobson, a perspectiva funcional de Halliday, a etnolingüística da comunicação desenvolvida por Hymes $^{14}$, os avanços da etnometodologia e da sociolingüística interacional a partir da tematização dos conceitos de rotina e de norma. Mas, como bem lembra Bouquet, é o artigo de Mikhail Bakhtin intitulado "Os gêneros do discurso" que pode ser visto como um verdadeiro manifesto teórico em favor de uma lingüística dos gêneros.

${ }^{10}$ O autor (2004: 38) defende uma definição dos gêneros de discurso que passa pela articulação e a correlação dos dados dos três níveis, são eles: o nível situacional (contrato global do domínio de comunicação); o das restrições discursivas (a organização discursiva e seus modos advindos dos dados situacionais); o da configuração textual (formas textuais recorrentes que testemunham as regularidades de um texto).

${ }^{11}$ Essa distinção é de suma importância para o autor, pois alguns autores empregam os termos gêneros e tipos de discurso indiferentemente. Assim, o editorial constitui um gênero de discurso no interior do tipo de discurso jornalístico. Tomando as palavras do autor, "os gêneros de discurso pertencem a diversos tipos de discurso associados a vastos setores de atividade social” (2001: 61).

${ }^{12}$ Sabemos que o artigo "gêneros do discurso" (1952-1953) já tinha sido escrito por M. Bakhtin, mas este ainda não fazia parte dos estudos lingüísticos que dominavam esse cenário. Por isso não o citamos como embrião dessa questão nos anos 60. Procuramos nos limitar aos lingüistas que, de uma certa forma, faziam parte das discussões. Acrescentando, a leitura de M. Bakhtin só acontece nos anos 70, com a tradução de Marxismo e Filosofia da Linguagem. Posteriormente, chega à Europa ocidental a tradução de "gêneros do discurso", artigo que, certamente, impulsiona os estudos dos gêneros no campo da lingüística.

13 Essa prática de uma lingüística do gênero, segundo Bouquet (2004:13), visa a acreditar em uma não diferenciação entre gênero de texto e gênero do discurso. Dessa forma, não haveria necessidade de conferir ao conceito de gênero o estatuto distintivo frente a conceitos de discurso, tipo, modo, campo genérico,etc. Diante desse quadro, o autor acredita que o objeto gênero pode ser entendido por seu significado suprasegmental no seio de um sistema.

14 Os estudos de Hymes, conforme Bouquet (2004: 5), representam “uma baliza epistemológica importante para a química de uma teoria dos gêneros: Hymes considera de fato que um conceito geral de gênero é necessário à análise da parole e constitui uma determinação, tradicionalmente ignorada, de características formais dos enunciados”. 
Sem dúvida, as reflexões contemporâneas acerca dos gêneros não podem deixar de mencionar o trabalho de Bakhtin cujo pensamento redimensiona a problemática dos gêneros do discurso, trazendo-a para o campo da linguagem, mas não a limitando às questões de literatura e retórica. Segundo pesquisadores da obra de Bakhtin, esse impulso se deve, justamente, à publicação do artigo “os gêneros do discurso”, mas tomando o pensamento bakhtiniano de forma linear, podemos observar como os gêneros constituem de fato uma preocupação constante do seu pensamento. Por exemplo, ao tratar do problema do texto (2003), Bakhtin aponta reflexões sobre os gêneros discursivos abordando a importância de um estudo que visa a não exclusão de uma tipologia estilístico-composicional. Diz o autor: "os gêneros do discurso são modelos tipológicos de construção da totalidade discursiva. Entretanto esses modelos de gênero diferem essencialmente dos modelos lingüísticos de orações”. Essa totalidade discursiva se dá em dois pólos que, segundo Bakhtin, residem concomitantemente no individual, único e singular, ou seja, a intenção em razão da qual o texto foi criado, e a sua relação dialógica indissoluvelmente ligada ao elemento autoria que se revela na cadeia dos textos. Segundo Todorov (1981: 124), esse projeto (que pode ser encontrado desde o livro ${ }^{15}$ de Medvedev/Bakhtine, datado de 1928) comunga com “duas escolhas metodológicas iniciais, a não separação entre forma e conteúdo, e a predominância do social sobre o individual”. Portanto, uma análise dos gêneros do discurso deve levar em consideração os dois pólos do texto.

Para abordar a questão dos gêneros, inscrevemo-nos na perspectiva da $\mathrm{AD}$ de linha francesa, cujo quadro epistemológico situa-se, conforme Pêcheux \& Fuchs (1975), na articulação do materialismo histórico, da lingüística e da teoria do discurso, além da teoria de subjetividade (de natureza psicanalítica) que atravessa essas três regiões do conhecimento científico.

Rompendo com a análise de conteúdo e com a análise de texto em uso no campo das ciências sociais, vigente na segunda metade do século XX, Pêcheux desenvolve a análise automática do discurso a fim de fornecer a esse campo um novo instrumento científico e teórico que, segundo Maldidier (2003), será postulado nem para substituir uma teoria da ideologia nem uma teoria do inconsciente, mas intervindo no campo

\footnotetext{
${ }^{15}$ The formal method in literary scholarship. A critical Introduction to sociological poetics.
} 
dessas teorias. Desse modo, Pêcheux procura compreender, passando pela ideologia, a ligação entre o discurso e a prática política. Para buscar tal compreensão, o autor diz ser “impossível analisar um discurso como um texto, isto é, como uma seqüência lingüística fechada sobre si mesma, mas que é necessário referi-lo ao conjunto de discursos possíveis a partir de um estado definido das condições de produção” (1969: 79).

O questionamento do processo de produção do discurso leva Pêcheux a desenvolver conceitos que serão norteadores à AD. São eles: o conceito de formação discursiva e o de formação ideológica. Durante as três fases da $\mathrm{AD}^{16}$, pode-se observar como esses conceitos são nucleares, deixando à margem conceitos como o de gêneros do discurso que aparece na sua obra como co-adjuvante em dois momentos:

1) na primeira fase, para explicar como um discurso é sempre pronunciado a partir de condições de produção dadas, o autor utiliza o gênero sermão e o gênero “conversa a bandeiras despregadas” para exemplificar como ocorre, de modo diferente, o funcionamento da instituição no que toca à questão da relação orador/ouvinte (1969: 78);

2) na segunda fase, para explicar o caráter material do sentido que adquirem as palavras e os enunciados em referência às formações ideológicas e discursivas, Pêcheux cita o gênero arenga, o gênero sermão, o gênero panfleto, etc. para exemplificar como o gênero está articulado ao que pode e deve ser dito a partir de uma posição dada numa conjuntura específica (1975: 160).

\footnotetext{
${ }^{16}$ A primeira fase da AD é marcada pela exploração metodológica do processo de produção discursiva fechada sobre si mesma, ou seja, seu ponto de partida é um corpus fechado de seqüências discursivas selecionadas num espaço discursivo supostamente dominado por condições de produção estáveis e homogêneas. Nessa prática, a existência do outro está subordinada ao primado do mesmo.

A segunda fase da AD é marcada por um deslocamento teórico. Diferente da AD-1, na perspectiva da AD-2 o processo de produção discursiva não se dá de forma fechada sobre si, mas sobre as relações de força desiguais entre os processos discursivos. Isto é, uma FD não é mais vista como um espaço estrutural fechado, mas como um espaço constituído por outras FDs sob a forma de pré-construídos e de discursos tranversos. Diante desse quadro, é introduzida a noção de interdiscuso, mas o fechamento da maquinaria ainda é conservado como efeito do sujeito assujeitado.

A terceira fase da $\mathrm{AD}$ é marcada pela acentuação do primado teórico do outro sobre o mesmo. Frente a esse quadro, emerge a questão da heterogeneidade enunciativa. Nessa fase, o importante é abordar as formas lingüísticas do discurso-outro através das numerosas pesquisas sobre os encadeamentos intradiscursivos. (PECHEUX: 1983, 311-318)
} 
Buscamos, assim, descrever a problemática dos gêneros nos territórios da AD, tendo em vista as reflexões de Dominique Maingueneau. Como dissemos, esse conceito ocupava um espaço periférico, mas à medida que a $\mathrm{AD}$ começa a dialogar com a Pragmática, ocorre um deslocamento dessa questão que passa a se tornar cada vez mais nuclear. Esse deslocamento fica visível na obra de Maingueneau, pois ao abordar essa problemática em Novas tendências em análise do discurso (1997), o autor a expõe via pragmática que procura conceber o gênero de forma “institucional”, e não a partir do conjunto de características formais. Mas, para AD, a explicitação das condições genéricas não se constituía como uma problemática para a teoria, uma vez que visa a analisar coerções referentes à formação discursiva. Segundo Maingueneau (1997: 37),

(...) ao considerar, por exemplo, manifestos surrealistas, sua intenção não será a de examiná-los como amostras do gênero "manifesto", mas, antes, para compreender como o discurso surrealista investe as regras próprias deste gênero. Na realidade, este investimento pode realizar-se das múltiplas maneiras, de acordo com as formações discursivas consideradas, indo desde a perfeita concordância até o conflito.

Mas o caráter dinâmico das reflexões sobre gênero leva a $\mathrm{AD}$ e as correntes pragmáticas a colocarem essa problemática no centro de suas preocupações. Os estudos sobre o discurso tomaram outras veredas, não há mais um único acesso ao discurso, mas uma multiplicidade de acessos governados por preocupações variadas. Dentre essa multiplicidade de acesso à atividade enunciativa, podemos nos deparar com a problemática dos gêneros discursivos. No prefácio de Análise de textos de comunicação (2000: 12), Maingueneau reforça a importância dos estudos sobre os gêneros de discurso:

Em nosso manual, adotamos o ponto de vista da análise do discurso, que não apreende nem a organização textual em si mesma, nem a situação de comunicação, mas procura associálas intimamente. Um texto publicitário, por exemplo, não é estudado exclusivamente como um tipo de estrutura textual, uma seqüência coerente de signos verbais, nem como um tipo de 
estrutura textual, uma seqüência coerente de signos verbais, nem como um dos elementos da estratégia de marketing, mas como uma atividade enunciativa ligada a um gênero de discurso: o lugar social do qual ele emerge, o canal por onde passa (oral,escrito, televisivo...), o tipo de difusão que implica etc., não são dissociáveis do modo como o texto se organiza. O analista do discurso pode tomar como base de trabalho um gênero de discurso (uma consulta médica, uma aula de língua, um debate político na televisão...), ou um setor do espaço social (um serviço de hospital, um café, um estúdio de televisão...), ou ainda um campo discursivo (político, cientifico...); mas ele só parte de um gênero para situá-lo em seus lugares, e só delimita um lugar para examinar que gênero(s) de discurso lhe é(são) associado(s).

Toda essa discussão inicial, a nosso ver, ratifica o nosso posicionamento em procurar articular formas lingüísticas e funcionamento discursivo dos gêneros. Nessa perspectiva, centraremos as discussões deste trabalho em torno das questões levantadas pela análise do discurso, principalmente as questões propostas por Maingueneau. Embora não operemos com as categorias de Bakhtin, trouxemos para esse capítulo alguns apontamentos do teórico russo acerca dessa problemática. Sempre que a questão de gênero é abordada, há um eco do pensamento bakhtiniano. Por exemplo, para explicar a utilidade dos gêneros do discurso, Maingueneau caminha em direção às reflexões de Bakhtin, pois, segundo o teórico francês, o fato de um locutor dominar vários gêneros de discurso é um fator de considerável economia cognitiva, por isso somos capazes de identificar um dado enunciado como receita ou como editorial ou como petição, sem precisarmos estar constantemente atentos a todos os detalhes dos enunciados que nos circundam. Ou seja, a comunicação é sempre assegurada pela competência genérica partilhada pelos membros de uma sociedade.

\subsection{Bakhtin: observações sobre a teoria dos gêneros}

Para o teórico russo, o gênero é um acontecimento tanto sócio-histórico quanto formal, isto é, existe um elo entre sociedade e linguagem. Em decorrência desse elo, suas transformações acompanham, principalmente, as mudanças que transcorrem nas esferas sociais. Assim, cada gênero será uma maneira particular de construir e abarcar o 
todo, pois como bem lembra Bakhtin ao iniciar o texto “Os gêneros do discurso" (In: Estética da Criação Verbal, 2003: 261):

Todos os diversos campos da atividade humana estão ligados ao uso da linguagem. Compreende-se perfeitamente que o caráter e as formas desse uso sejam tão multiformes quanto os campos da atividade humana (...) O emprego da língua efetua-se em forma de enunciados (orais e escritos) concretos e únicos (...) Esses enunciados refletem as condições específicas e as finalidades de cada referido campo não só por seu conteúdo (temático) e pelo estilo de linguagem, ou seja, pela seleção dos recursos lexicais, fraseológicos e gramaticais da língua, mas, acima de tudo, por sua construção composicional.

Partindo dessa citação, podemos dizer que Bakhtin define a categoria de gênero como uma forma relativamente estável de enunciado, sujeita aos movimentos históricos e presente em todas as esferas das atividades humanas, cujo emprego depende de uma temática, de um estilo e de dada estrutura composicional. Por exemplo, tomando o gênero "receita culinária”, embora haja diferenças entre elas, todas devem ter propriedades que as identificam como uma espécie de texto que integra um mesmo gênero (no dizer de Maingueneau, uma mesma cena genérica). Para ser uma receita, a temática do texto deve ser marcada por informações sobre os ingredientes e o modo de preparo. O estilo deve criar um efeito de sentido de objetividade e de aproximação, como se o enunciador estivesse falando passo a passo como preparar tal receita. Esse efeito é caracterizado pelas formas verbais imperativas e pelas seqüências tipológicas do tipo injuntivo-descritivo. Já a forma composicional da receita é apresentar a seguinte estrutura típica: “ingredientes” e "modo de preparo”. Sem essas características, um texto não pode ser classificado como “receita culinária”.

O conceito de gênero, segundo Bakhtin, está ligado ao conceito do enunciado concreto (unidades reais da cadeia verbal que não devem ser estudadas separadas do curso histórico das enunciações). Portanto, a concepção dos gêneros de discurso é determinada pela situação social imediata e o meio social mais amplo. Ou seja, a situação dá forma à enunciação (aos gêneros de discurso). Essa é a razão de um olhar voltado para a natureza lingüística do enunciado, pois é preciso comunicar o extraverbal (social) e o lingüístico. 
Tomando o conceito de enunciado concreto como chave para entender a problemática dos gêneros, podemos, desde já, afirmar que um gênero qualquer "só poderá aparecer em um terreno interindividual”. Isso implica em dizer que a existência dos gêneros se dará a partir da materialização da comunicação entre dois sujeitos que estejam organizados socialmente, pois, segundo Bakhtin, é nisso que consiste o complexo problema da relação de reciprocidade entre linguagem e ideologia.

Em decorrência dessa natureza do enunciado, não podemos falar em gênero sem pensar na sua heterogeneidade, ou seja, na riqueza e diversidade de seu repertório que "cresce e se diferencia à medida que se desenvolve e se complexifica um determinado campo”. Por isso, o estudo dos gêneros não pode ser visto sob uma óptica homogênea, mas levando em conta seu caráter heterogêneo, pois é "através de enunciados concretos que a vida entra na língua”.

Entendendo o enunciado como unidade da comunicação discursiva, Bakhtin critica a função comunicativa da linguagem que vê o papel do ouvinte na sua compreensão passiva do falante. Para o teórico russo, a forma clássica dessa comunicação discursiva é o diálogo cujos limites são definidos pela alternância dos sujeitos do discurso. O sujeito/ouvinte ocupa uma ativa posição responsiva em relação ao sujeito/falante, ao longo de todo o processo de audição e compreensão desde o seu início.

Essa atividade responsiva do enunciado amplia a noção de contexto; o enunciado está relacionado com o contexto extraverbal da realidade (a situação, o ambiente, a história) e como os enunciados outros, pois “cada enunciado é um elo na corrente complexamente organizada de outros enunciados”. É, então, dentro dessa noção de contexto amplo que se molda o discurso em forma de gêneros, ora padronizada e estereotipada, ora flexível, plástica e criativa. Em suma, podemos dizer que os gêneros são da mesma natureza do enunciado. Tal observação pode ser demonstrada no seguinte trecho:

Nós aprendemos a moldar o nosso discurso em formas de gênero e, quando ouvimos o discurso alheio, já adivinhamos o seu gênero pelas primeiras palavras, adivinhamos um determinado volume (isto é, uma extensão aproximada do conjunto do discurso), uma determinada construção composicional, prevemos o fim, isto é, desde o início temos a sensação 
do conjunto do discurso que em seguida apenas se diferencia no processo da fala. Se os gêneros do discurso não existissem e nós não os dominássemos, se tivéssemos de criá-los pela primeira vez no processo do discurso, de construir livremente e pela primeira vez cada enunciado, a comunicação discursiva seria quase impossível. (BAKHTIN, 2003a: 283)

Diante dessa problemática, o autor distingue os gêneros em primários (constituídos em situações de comunicação ligadas a esferas sociais cotidianas de relação humana) e secundários (relacionados às esferas públicas e mais complexas, de interação social). Essa perspectiva não é dicotômica, uma vez que mostra a inter-relação existente entre os dois grandes tipos de gênero, afirmando que os secundários absorvem e transmutam os primários, ou seja, os gêneros primários, ao se tornarem componentes dos gêneros secundários, transformam-se dentro destes e adquirem uma característica particular. Essa distinção é de grande importância para o autor, que diz não se tratar de uma diferença funcional, mas de uma classificação que visa a descobrir a natureza complexa e profunda do enunciado. Nesse processo de investigação dos gêneros, é preciso reconhecer a sua natureza, as suas peculiaridades, ou melhor, a sua materialidade lingüística concreta.

Nesse processo de investigação reside a complexidade da questão metodológica, pois muitos estudos, ao buscar reconhecer a materialidade lingüística de um enunciado, obliteram as incursões estilísticas. Para Bakhtin, onde há estilo há gênero, ou seja, os estudos dos gêneros devem reservar na sua metodologia um espaço para as questões de estilo, pois todo estilo está indissoluvelmente ligado aos gêneros do discurso. Por isso, é preciso "encarar o estilo como efeito de sentido, produzido no e pelo discurso, reconhecido pelo fazer interpretativo de um enunciatário, cúmplice de um sujeito da enunciação, para que, juntos, construam um efeito de individuação (...) da recorrência formal das relações na construção do significado, o resultado da própria individuação. Mas (...) também refletir sobre estilo, como construção de um sujeito por uma totalidade de discursos” (DISCINI, 2003: 26). 


\subsection{AD e a problemática dos gêneros}

Nesse momento do capítulo, centramo-nos nas considerações de Maingueneau acerca dessa problemática. Dessa forma, podemos observar como Maingueneau (1984, 1997, 2001, 2004), vai dando a essa questão um redimensionamento, trazendo-a para o cerne das questões da $\mathrm{AD}$. E à medida que essa reflexão progride, o autor francês a associa à problemática do ethos, uma vez que ambos (gênero e ethos) estão relacionados com a cena de enunciação.

Como observamos inicialmente, a categoria do gênero de discurso permite à $\mathrm{AD}$ um contato com a Pragmática. É, então, através desta que o conceito se desenvolve. Lembremos como Maingueneau aborda essa questão em Novas tendências em análise do discurso (1997), traçando um paralelo entre ato de fala e gêneros do discurso, mostrando que um gênero implica condições de ordens comunicacional e estatutária.

Esse contato com a Pragmática não deixa de reaparecer na obra de Maingueneau, pois em Análise de textos de comunicação (2001), para caracterizar os gêneros de discurso, recorre ao valor pedagógico de três metáforas: o contrato, o papel e o jogo. Segundo o autor, essas metáforas ajudam a designar dispositivos de comunicação sócio-historicamente definidos e elaborados, uma vez que "no âmbito da Análise do Discurso, a categoria gênero do discurso é mais comumente definida a partir de critérios situacionais”. Assim, partindo desses critérios, os gêneros devem ser caracterizados por certos parâmetros, tais como: finalidade reconhecida, estatuto de parceiros legítimos, enquadramento espaço-temporal, suporte material, organização textual, etc. Esses parâmetros devem ser vistos como um conjunto de condições de êxito por ser o gênero “um ato de linguagem de um nível de complexidade superior”. Nesse sentido, falar dessas condições de êxito é se aproximar de um quadro pragmático que julga a "felicidade" de um ato de fala, partilhado pelos membros de uma comunidade, assegurando sua comunicação a partir de uma competência genérica, pois “para um locutor, o fato de dominar vários gêneros de discurso é um fator de considerável economia cognitiva”.

Conforme observamos, Maingueneau mostra, em sua obra, que para abordar essa questão da genericidade é preciso estabelecer uma articulação do social com o 
lingüístico, pois a categoria dos gêneros de discurso mobiliza tipologias enunciativas (de critério lingüístico), funcionais e situacionais. Nesse sentido, a noção de gêneros discursivos apresenta um estatuto tipológico bastante incerto e parece não se deixar enquadrar em nenhuma das tipologias, mas as atravessa. Logo, segundo o autor (1999b: 47), “é possível falar em uma categoria propriamente discursiva, que não se deixa reduzir a uma grade estritamente lingüística nem a uma grade de ordem sociológica ou psico-sociológica”17. É esse estatuto discursivo que traremos para a análise do gênero coluna feminina.

Para dar um estatuto discursivo à noção de gênero do discurso, partimos do princípio de que os discursos se desdobram sobre um espaço institucional, ou seja, na imbricação de um discurso e de uma instituição. É nessa imbricação que os gêneros são produzidos e se fazem circular. Na pesquisa realizada, o gênero discursivo coluna feminina se configura na imbricação do discurso da mulher esclarecida e da instituição imprensa feminina. Nesse sentido, o modo como os gêneros se fazem circular está associado às suas condições de emprego, pois a maneira pela qual um gênero textual é produzido depende da maneira pela qual é consumido, segundo Maingueneau (2005: p.141), “o modo de difusão vai de mãos dadas com o modo de consumo do discurso, isto é, com o que se faz dos textos, como eles são lidos, manipulados”. Adotando esse posicionamento, confere-se à categoria dos gêneros um estatuto para além do formal.

Partindo de um procedimento "global", Maingueneau apreende os gêneros discursivos tanto na ordem do enunciado quanto na da enunciação. Ou melhor, os gêneros são apreendidos em sua cena enunciativa que se distingue em três planos: cena englobante, cena genérica e cenografia.

É importante chamar atenção para a cena enunciativa que, segundo Maingueneau, se mostra com maior evidência quando textos são relacionados a seus gêneros discursivos. Para ele, pode-se falar de “cena” para caracterizar qualquer gênero, pois ela corresponde ao rastro deixado por um discurso em um texto onde a fala é encenada, com isso "acentua-se o fato de que a enunciação acontece em um espaço instituído, definido pelo gênero de discurso, mas também sobre a dimensão construtiva do discurso, que se coloca em cena” (2004: 95).

\footnotetext{
17 “On peut donc parler ici d’une catégorie proprement discursive, qui ne se laisse réduire ni à une grille stricitement linguistique ni à une grille d’ordre sociologique ou psycho-sociologique”.
} 
Tomando Feira de utilidades como exemplo, se levarmos em conta que a cena de enunciação é a de um texto jornalístico, limitamos nossa reflexão ao tipo de discurso; se concebemos a cena de enunciação como a de uma coluna feminina que procura aconselhar suas leitoras, limitamos nossa reflexão ao gênero de discurso; mas se percebemos que essa cena é a de uma conversa entre amigas em que uma se mostra esclarecida, capaz de aconselhar, observamos, então, a cena construída pelo texto, ou seja, observamos a sua cenografia. Partindo dessa exemplificação, revisitemos, então, os conceitos de cena englobante, cena genérica e cenografia.

A cena englobante, segundo Maingueneau (2004), corresponde ao tipo de discurso, atribuindo este seu estatuto pragmático. Essa corresponde a práticas sociais mais amplas, mais abrangentes do que os gêneros, uma vez que distintos gêneros podem integrar a mesma “cena englobante”, ou um gênero pode integrar "cenas englobantes” diferentes. Por exemplo: a crônica pode circular tanto na esfera ${ }^{18}$ do discurso jornalístico, quanto na esfera do discurso literário; a receita culinária pode circular tanto na esfera do discurso jornalístico, quanto na esfera do discurso publicitário. Com relação à Feira de utilidades, sua prática social mais ampla é a imprensa feminina.

A cena genérica corresponde aos critérios de êxito com os quais o texto está em conformidade. Esses critérios são: uma finalidade reconhecida; o estatuto de parceiros legítimos; o lugar e o momento legítimos; um suporte material; uma organização textual, etc. Para o autor, a imbricação das duas cenas (englobante e genérica) define o espaço estável, denominado quadro cênico do texto, no interior do qual o enunciado adquire sentido e com o qual está, pragmaticamente falando, em conformidade.

A cenografia, embora esteja associada à noção dos gêneros discursivos, não é imposta por eles. Ela se constitui pelas relações estabelecidas no próprio texto, por isso não podemos entendê-la como um simples "quadro, uma decoração, como se o discurso viesse do interior de um espaço já construído, independente deste discurso” (2004: 49).

Partindo dessa tripla interpelação, o autor, procurando focalizar a diversidade dos gêneros instituídos ${ }^{19}$, propõe uma divisão destes em quatro modos, cujo princípio de classificação se estabelece na relação entre a cena genérica e a cenografia.

\footnotetext{
${ }^{18}$ Segundo Grillo (2004: 36), “na terminologia de Bakhtin, o tipo de discurso corresponde a uma esfera de utilização da língua ou de comunicação verbal”.

${ }^{19}$ Essa definição (classificação) corrobora com suas reflexões inicias acerca das práticas discursivas, pois, segundo Maingueneau,os discursos desenvolveriam sua organização em comunhão com a instituição em
} 
Os gêneros de modo I são os que apresentam uma cena genérica fixa, não estando sujeitos à variação, caracterizados por fórmulas e esquemas composicionais preestabelecidos; os de modo II são produções individualizadas, mas submetidos a normas que definem o conjunto de parâmetros do ato comunicacional. E mesmo seguindo uma cenografia preferencial, tolera cenografias mais originais; os de modo III não apresentam uma cenografia preferencial, pois sua natureza incita a inovação, por exemplo, os gêneros publicitários; por último, os de modo IV são os propriamente autorais e cuja “cena genérica é tomada por uma incompletude constitutiva”.

Olhando para o nosso corpus, podemos inferir que, no interior da coluna, há gêneros discursivos que apresentam um enquadramento maior, ou melhor, apresentam características genéricas muito mais definidas, como é o caso das receitas, das dicas de beleza, etc. Porém, o texto de abertura se mostra de forma diferente por prevalecer não o quadro cênico, mas a cenografia que corresponde, justamente, à cena de enunciação que legitima todo discurso, sendo "ao mesmo tempo a fonte do discurso e aquilo que ele engendra”, isto é, “o discurso, em seu próprio desenrolar, pretende convencer, instituindo a cena de enunciação que o legitima”.

Embora Maingueneau trabalhe com esses quatro modos de genericidade, preferimos, no percurso de análise, apreender o gênero coluna feminina e seus subgêneros (receita, dicas, editoriais, etc.) apenas na relação que se estabelece entre cena genérica e cenografia, sem nos preocuparmos com tipologias. Nesse sentido, defendemos a hipótese de que todos os gêneros apresentam um grau variado de cenografia, ou seja, essa relação entre cena genérica e cenografia se dá num continuum, havendo sempre uma cenografia presente no texto, por mais ínfima que seja.

E para observar essa relação entre cena genérica e cenografia, adotamos o procedimento metodológico de Maingueneau que se funda sobre uma semântica global, cujo procedimento apreende o discurso integrando tanto os planos na ordem do enunciado quanto na da enunciação.

que se inserem, logo a instituição não poderia ser entendida como simples suporte, mas como elemento constituinte dos gêneros discursivos. Por isso, o conteúdo dos editoriais da coluna está em estreita relação com a instituição em que são produzidos e consumidos. 
A nosso ver, apreender a semântica global é observar a relação orgânica e indissolúvel do estilo com o gênero, uma vez que essa semântica rege: os tipos de relações intertextuais que a competência discursiva define como legítimas; os temas e vocabulários impostos e específicos de um certo espaço discursivo; o modo como cada gênero define o estatuto do enunciador e do destinatário; a dêixis que cada discurso constrói em função de seu próprio universo; o modo de enunciação, isto é, a maneira de dizer específica de um discurso; e, por fim, o modo de coesão próprio de cada formação discursiva.

Porém, ao buscarmos apreender a semântica global que rege um gênero discursivo, não podemos deixar de observar como o gênero, através de um sistema de restrições, articula discursos e instituições, pois “a organização dos homens aparece como um discurso em ato, enquanto que o discurso se desenvolve sobre as próprias categorias que estruturam essa organização” (MAINGUENEAU, 2005: 134). 


\title{
Em “cena” Feira de utilidades: do discurso à prática discursiva
}

\author{
"Mas há alguma coisa que é preciso ser dita, é preciso ser dita. \\ - Vou te dizer o que eu nunca disse antes (...) \\ Se eu não disse é porque não sabia que sabia \\ - mas agora eu sei." \\ Clarice Lispector, A descoberta do mundo.
}

\subsection{Considerações iniciais}

No capítulo anterior, mostramos que a complexidade dos gêneros do discurso se deve à diversidade dos pontos de vista que cercam duas orientações teóricas principais: uma voltada para os textos e outra para as condições de produção do discurso. Neste trabalho, postulamos que a noção de gêneros do discurso se dá não na divergência, mas na junção dessas duas orientações teóricas. Para observar tal junção, temos em vista os pressupostos teórico-metodológicos de Maingueneau que aborda a problemática do gênero enquanto prática discursiva, como um ritual convencionado socialmente e submetido a um critério de êxito que envolve elementos de ordem textual e não textual: uma finalidade reconhecida; o estatuto de parceiros legítimos; o lugar e o momento legítimos; um suporte material; uma organização textual.

Retomando as palavras de Maingueneau em "Do discurso à prática discursiva" (In: Gênese dos discursos, 2005), procuramos, neste capítulo, mostrar que "a enunciação não tem só um rio acima, ela também tem um rio abaixo, a saber, as condições de emprego dos textos do discurso" (p.140). Seguindo o curso do rio, somos levados a abordar a problemática dos gêneros e responder à questão como se dá o funcionamento da coluna "feira de utilidades" no seu campo discursivo (imprensa feminina)?

No curso dos pressupostos teóricos de Maingueneau, não vamos conferir a essa problemática um estatuto formal, mas um estatuto que se estabelece na relação entre o conjunto de propriedades mais convencionais/ritualizadas (cena genérica) e a 
cenografia. A análise do gênero instituído - coluna feminina - focaliza essa relação que se estabelece entre cena genérica e cenografia.

Como gênero instituído, a coluna feminina Feira de utilidades agrupa traços autorais e rotineiros. A coluna é um gênero determinado por quem a edita (Helen Palmer) e os indícios autorais aparecem justamente no modo como os temas rotineiros (maternidade, casamento, cuidado de si), comumente associados a essa prática discursiva, são tratados. A nosso ver, os parâmetros que constituem o gênero coluna feminina não são fruto apenas de uma atividade verbal ritualizada em uma determinada situação social, mas uma prática que resulta, também, de variações individuais, ou seja, a prática desse gênero não pode ser definida como totalmente ritualizada porque no seu interior podemos observar traços de singularidade que revelam um modo de enunciar... uma tomada de posição num discurso.

Neste momento do trabalho, optamos por focalizar o caráter ritualizado da coluna feminina. A questão do caráter autoral, dos traços de singularidade da coluna que revelam uma tomada de posição, será focalizada no próximo capítulo, quando abordaremos a noção de ethos.

Ao verificarmos um padrão no modo como a coluna é difundida a partir das várias incursões realizadas nas noventa e seis colunas, analisamos um exemplar de Feira de utilidades, cuja descrição se segue. Como todos os exemplares apresentam uma cena genérica fixa, um deles mostra como os outros são, dando uma idéia geral do funcionamento de Feira de utilidades, ou seja, de como todos os exemplares encontramse submetidos às mesmas condições de êxito, de como os temas impostos pela imprensa feminina são abordados, enfim, de como a coluna, no fim dos “anos dourados”, estabelece seu elo com seu campo de atividade - a imprensa feminina da época.

Árduo trabalho foi, então, selecionar uma dentre as noventa e seis colunas. A princípio pensamos em fazer uma escolha aleatória, uma vez que um exemplar mostra como são os outros. Mas observamos que essa escolha não poderia ser aleatória e decidimos adotar dois critérios para a seleção da coluna: 
O primeiro critério seria delimitar o assunto-chave que perpassava a discursividade da imprensa feminina nos anos 50. Ao ler a pesquisa de Bassanezi (1992), vê-se que, nos anos dourados, na ideologia das revistas femininas, a prática do casamento, como momento e constituição da família, permitia à mulher exercer seus papéis de mãe, esposa e dona de casa. Nesse sentido, tomamos como assunto-chave o "vínculo conjugal”;

O segundo critério seria selecionar uma coluna que tivesse sido publicada nem próximo à primeira edição (agosto de 1959), nem próximo à última edição (fevereiro de 1961). Por isso, selecionamos a coluna publicada em 24 de janeiro de 1960.

Gostaríamos de esclarecer que não estamos desprezando as demais colunas e os demais temas possíveis. Temos consciência de que cada coluna estabelece um elo com as demais colunas, por isso, ao longo do capítulo nos deparamos com formulações presentes em outras colunas.

Adotando os critérios acima, iniciamos o curso da análise "rio abaixo", tecendo considerações sobre o surgimento da coluna e suas coerções. Seguindo "rio abaixo", mostramos o lugar ocupado pelos dispositivos midiológicos na legitimação da coluna Feira de utilidades. Finalmente chegamos à foz do rio! Em consonância com os pressupostos teóricos de Maingueneau, analisamos o modo como a coluna Feira de utilidades estabelece seu estatuto genérico na relação entre “cena genérica” e “cenografia”.

\subsection{Feira de utilidades: em “cena” as coerções}

A coluna feminina Feira de utilidades surge em 21 de agosto de 1959 e consolida, no matutino Correio da Manha ${ }^{20}$, um novo espaço destinado aos "assuntos

\footnotetext{
${ }^{20}$ Em 15 de julho de 1901, era publicada em seis páginas a primeira edição do matutino Correio da Manhã. Tendo como diretor Edmundo Bittencourt, o matutino, situado à rua Moreira César $\mathrm{n}^{\circ} 117$, mostrava o seu ferrenho oposicionismo à prática jornalística da época. Segundo Sodré (1966: 328-329),
} 
femininos”. Digo um novo espaço porque, aos domingos, o matutino já publicava o suplemento Correio Feminino, destinado à mulher dona-de-casa, mãe e esposa.

Publicada às quartas e sextas-feiras na quinta página do segundo caderno, a coluna surge numa época em que a classe média ascende; em que o país assiste a um momento de otimismo e crescimento econômico; em que é possível observar um aumento das possibilidades educacionais e profissionais para as mulheres; em que a imprensa feminina, influenciada pelas campanhas estrangeiras, pregava a volta das mulheres ao lar e aos valores tradicionais da sociedade. Na ideologia das páginas de revistas e de jornais destinadas ao público feminino, a mulher ideal, segundo Bassanezi (1992), era definida a partir da “verdadeira” essência feminina - maternidade, casamento e dedicação ao lar. Essa vontade de “verdade” exerce sobre Feira de utilidades uma espécie de pressão, isto é, um poder de coerção. Isso nos leva a refletir sobre a maneira como Feira de utilidades está vinculada à atividade dessa imprensa feminina dos anos 50 .

Tendo adotado a perspectiva teórica de Maingueneau, vemos a imprensa feminina como "cena englobante” que controla a produção dos textos que circulam sob o seu domínio. Estando Feira de utilidades sob coerção dessa “cena englobante”, é visível observar na discursividade da coluna a distinção entre os papéis femininos e masculinos: as mulheres responsáveis pelas tarefas domésticas; os homens responsáveis

essa prática está em completa relação de dominação à política do então Presidente Campos Sales, e o matutino romperia de vez o apoio ao governo que presidia a política de estagnação, onerando terrivelmente as classes populares. Dessa forma, quebrava-se "a placidez aparente, alcançada pelo suborno, pela sistematizada corrupção, institucionalizada a compra da opinião da imprensa”. Por isso, ao ser lançado, o matutino deixa explicitamente claro o seu caráter oposicionista no texto de abertura, escrito por Dr. Manoel Victorino. Nesse texto, em tom ácido, o enunciador expõe que o matutino vai se desgarrar da praxe vigente (a neutralidade) e vai se mostrar um jornal de opinião que defenderá a causa do povo, do comércio e da lavoura. Nas palavras do enunciador, este será um jornal sincero e independente que procurará a todo custo dizer a verdade. Vejamos alguns trechos:

“O correio da manhã não tem nem terá jamais ligação alguma com partidos políticos. É uma folha livre, que vae se consagrar com todo o ardor e independencia á causa da justiça, da lavoura e do commercio isto é, a defesa dos direitos do povo, do seu bem estar e das suas liberdades”;

“O povo está cansado, o povo sente que lhe occultam a verdade... o povo quer a verdade; elle comprehende que só ella salva e redime, embora ás vezes fira”.

Havia, também, um texto escrito por Bittencourt cujo objetivo era equiparar o jornal a uma obra de arte. No seu dizer, o jornal é mais dos seus leitores do que dos redatores ou do proprietário, e procurando implantar o tom de verdade que o jornal pretende assumir, Bittencourt escreve:

"Não é na vehemencia da linguagem que está a verdade ou a auctoridade d'aquillo que um jornal affirma. Quando essa vehemencia pudesse infundir o medo ou o terror a espíritos fracos, não é esse o sentimento que a imprensa moderna aspira; porém o do respeito, mixto de egualdade e de justiça, que a espontaneidade consagra approximando e não affastando, os que o inspiram e os que o sentem. (...) Que estas minhas idéas se infiltrem no jornal que se inaugura hoje como uma promessa bem fundada e como uma esperança auspiciosa e patriótica”. 
pelo sustento do lar. Retomando Foucault (2002b: 9), "sabe-se que não se tem o direito de dizer tudo, que não se pode falar de tudo em qualquer circunstância, que qualquer um, enfim, não pode falar de qualquer coisa”.

Vejamos dois outros elementos que impõem forma ritualizada à coluna. São eles: a “proposta de trabalho” assinada por Clarice Lispector e o "plano publicitário dos produtos Pond’s”. A “proposta de trabalho” apresentava os seguintes itens:

O item 1 anuncia a proposta de uma "seção feminina, assinada por um pseudônimo”. O item 2 explicita os itens: "Cada seção (sob o título geral permanente) teria uns dois ou três itens para assegurar a variedade, mesmo que fossem curtos; cada título sob um título atraente”; e os assuntos: “Os assuntos seriam beleza, moda, problemas de mãe e dona-de-casa, incluindo a chamada 'conversa mole’, mas informativa. Ou poderia versar apenas sobre beleza e moda”. O item 3 define o tom, que deveria ser entre íntimo, bem-humorado e experiente”. E o item 4 propõe a criação de uma personagem: “A seção poderia criar um personagem feminino permanente que falaria na primeira pessoa, contaria seus problemas de mulher e como os resolvera, falaria dos problemas de suas amigas, etc. O tom: o de uma pessoa razoavelmente inteligente, informada sem ser uma sábia, e inclusive as vezes indecisa como se contasse com a opinião da leitora. (Ou outro tom a combinar)”. O item 5 traz o preço mensal para a elaboração de tal serviço: 50 mil cruzeiros. (Gotlib, 1995: 331).

Obedecendo às coerções da "proposta de trabalho", a coluna apresentava um padrão na sua diagramação: em espaço vertical, deveria trazer textos curtos com títulos atraentes que abordassem "assuntos femininos”, ou seja, assuntos sobre beleza, moda, problemas de mãe e dona de casa; na parte superior da coluna, aparece sempre o nome Correio feminino, seguido do sub-título Feira de utilidades; logo abaixo, conforme o primeiro item da "proposta de trabalho", aparece o pseudônimo Helen Palmer, que assina a coluna; entre diversos textos, a coluna publicava um quadrinho cuja personagem feminina chamada Amélia relata suas descobertas e problemas; além do quadrinho, a materialidade pictórica da coluna era composta por fotos de mulheres trajando modelos elegantes; logo abaixo da fotografia, a leitora se deparava com uma legenda explicando a que coleção os elegantes modelos pertenciam. 
O “plano publicitário dos produtos Pond's”, conforme Gotlib (1995: 332), deveria ser: escrito em "linguagem coloquial e simples, tão ao agrado das mulheres"; publicado "com conselhos de beleza, de elegância, de educação dos filhos, culinária, de todos os assuntos, enfim, que interessam à mulher e ao lar”; indireto, ou seja, indicar não o nome do produto, mas apenas suas propriedades recomendáveis e a necessidade de seu uso. Nas formulações abaixo, verifica-se esse plano publicitário indireto:

- “(...) Assim que descobrimos uma ruga devemos recorrer imediatamente ao tratamento apropriado, e esse tratamento será a massagem com cremes à base de lanolina a qual alimenta a pele e impede o seu ressecamento, pois a pele ressequida enruga muito mais depressa. A lanolina, principalmente a lanolina umedecida, que é absorvida com maior rapidez e penetra profundamente, é o produto mais indicado para lubrificação e alimento da pele envelhecida (...)” (Correio da Manhã, 8 de fevereiro de 1960);

- “ (...) Durante o verão, você deve usar sempre uma proteção, um creme para pele seca, a fim de que os seus prazeres ao ar livre não sejam causa para envelhecimento prematuro, formação de ruga e outras feias conseqüências. Um creme à base de lanolina umedecida é ideal, porque a lanolina é a melhor amiga da nossa pele, devolvendo a umidade (...)” (Correio da Manhã, 10 de fevereiro de 1960).

Como podemos observar na "proposta de trabalho" e no "plano publicitário dos produtos Pond's”, para suscitar a adesão da leitora das páginas das revistas e suplementos que tratavam de “assuntos femininos”21, Feira de utilidades mostra-se herdeira de uma moral em que as mulheres nascem para ser dona de casa, esposa e mãe, e a felicidade conjugal depende dos esforços femininos em agradar filhos e marido,

\footnotetext{
${ }^{21}$ Segundo Bassanezi (2002: 609), as revistas femininas nos anos 50, Jornal das moças, Querida, Vida Doméstica, Você, as seções para mulher de $O$ Cruzeiro, "traziam imagens femininas e masculinas, o modelo de família - branca, de classe média, nuclear, hierárquica, com papéis definidos -, regras de comportamento e opiniões sobre sexualidade, casamento, juventude, trabalho feminino e felicidade conjugal. Essas imagens mais do que refletir um aparente consenso social sobre a moral e os bons costumes, promoviam os valores de classe, raça e gênero dominantes de sua época. Como conselheiras, fonte importante de informação e companheiras de lazer - a TV ainda era incipiente no país -, as revistas influenciaram a realidade das mulheres de classe média de seu tempo assim como sofreram influências das mudanças sociais vividas - e algumas, também promovidas - por essas mulheres”.
} 
tendo como objetivo a harmonia do lar. A construção dessa discursividade pode ser exemplificada com a rede de formulações que são apresentadas como títulos de textos inseridos na coluna:

- "Pequenos conselhos para a dona de casa” (Correio da Manhã, 21 de agosto de 1959);

- “Cuidado com os seus filhinhos” (Correio da Manhã, 26 de agosto de 1959);

- “Compreenda o seu marido” (Correio da Manhã, 4 de setembro de 1959);

- “Ser mãe...” (Correio da Manhã, 9 de setembro de 1959);

- “Uma boa esposa” (Correio da Manhã, 11 de setembro de 1959);

- “Nova maneira de prender o marido” (Correio da Manhã, 4 de outubro de 1959);

- “Conselho às donas de casa” (Correio da Manhã, 28 de outubro de 1959);

- “Se o seu filho é problema” (Correio da Manhã, 6 de novembro de 1959);

- “Patroa e empregada” (Correio da Manhã, 11 de dezembro de 1959);

- “A colaboração no lar” (Correio da Manhã, 15 janeiro de 1960);

- “Expediente culinário” (Correio da Manhã, 20 de janeiro de 1960);

- “Diferentes concepções da maternidade” (Correio da Manhã, 12 de fevereiro de 1960);

- “Dirigir um lar” (Correio da Manhã, 24 de fevereiro de 1960);

- “Três pequenos conselhos às donas-de-casa” (Correio da Manhã, 2 de março de 1960)

- “Receita de casamento” (Correio da Manhã, 9 de março de 1960);

- “Pequenos segredos de cozinha” (Correio da Manhã, 2 de abril de 1960);

- “Felicidade conjugal” (Correio da Manhã, 22 de abril de 1960);

- "Para hemorragia nasal de seu filhinho" (Correio da Manhã, 2 de outubro de 1960); 
Mostrando-se herdeira dessa discursividade que limita a mulher à esfera do lar, Feira de utilidades não ignora a lógica da relação de dominação masculina e vai ao encontro das idéias sobre a diferença de gêneros predominante na sociedade. Assim, os diversos textos em torno dos quais a coluna se organiza materializam em suas formulações a distinção entre os papéis femininos e masculinos, como podemos visualizar no excerto intitulado A colaboração do lar:

As mulheres têm muita influência sobre a vida do marido, especialmente no setor de trabalho. Por trás de todo homem casado que trabalha, está a sombra da esposa. Esta poderá ajudá-lo a subir muito além dos outros, ou fará tanto peso para baixo que ele desistirá de lutar. Uma coisa é estimular pelo elogio e camaradagem, outra coisa é queixar-se todo dia de que ele não sobe na vida e ganha menos do que se gasta em casa. Isso pode arruinar a vida de um marido.

Que deve você fazer para animar o seu marido? Em primeiro lugar, mostrar-lhe por pequeninas coisas, que você tem confiança nele, que espera dele grandes coisas e que ele é seu herói. Faça a sua parte limpando a casa, preparando pratos saborosos e educando crianças. Ele se sentirá feliz num ambiente sossegado e poderá repousar melhor. No dia seguinte estará apto para enfrentar novas lutas e poderá conseguir novas vitórias (Correio da Manhã, 15 de janeiro de 1960).

Esse texto ilustra bem as reflexões de Bourdieu (2003) acerca da dominação masculina. Segundo o autor, a incorporação da dominação inscreve a ordem masculina no lado exterior, do oficial, do público, do descontínuo; já a ordem feminina se inscreve no lado do úmido, do baixo, do curvo, do contínuo e do privado, onde lhe são atribuídos os trabalhos domésticos. Nas formulações acima, podemos observar como o espaço ocupado pela mulher é contínuo e privado, estando ela associada ao espaço do lar; o homem, por sua vez, ocupa o espaço descontínuo e público, indo do trabalho para o lar, ou do lar para o trabalho. Podemos, também, observar como a postura submissa é imposta à mulher nesse texto, pois a mulher é a sombra do marido; é aquela que sempre espera a proteção do seu herói. Um outro ponto importante que podemos observar ao longo do texto é como a moral feminina se impõe através de uma disciplina incessante, relativa a como a mulher deve se comportar no lar quando o marido volta cansado do trabalho. Segundo as formulações do texto, a mulher deve estar sempre prestes a ajudálo, estimulando-o com elogios e camaradagem, não podendo se queixar do seu dia-adia. Com relação ao caráter, a mulher deve ser paciente, equilibrada e disciplinada para 
que o marido consiga sossego e descanso ao retornar ao lar. Sendo disciplinada e equilibrada, a mulher consegue ajudar o marido a subir e a enfrentar as batalhas do espaço público, pois sua vida depende do sucesso do marido no trabalho. A mulher como sombra deve ter bastante cuidado para não arruinar a vida do marido, porque, se ele tem sua vida arruinada, conseqüentemente ela terá sua vida arruinada também.

Para mostrar como Feira de utilidades está em plena comunhão com a sua “cena englobante”, vejamos um excerto de um texto publicado no Anuário das senhoras em 1954. No saber da imprensa feminina da época, a mulher esposa, mãe e dona de casa tem por obrigação ser paciente. As formulações abaixo reafirmam o caráter paciente imposto à mulher cuja finalidade é manter o casamento feliz:

A paciência é uma das grandes virtudes que a mulher deve possuir obrigatoriamente (...) A ela cabe olhar tudo com bom humor. Amando o marido, deve trazer a sua casa em socêgo e aconselhar seu companheiro, dando-lhe o consolo que necessita em certas ocasiões. Vendo-o aborrecido, deve procurar conhecer-lhe a causa para diminuir-lhe os danos com palavras carinhosas, bem pensadas. E não desesperá-lo mais, como fazem certas criaturas inconscientes. Sendo assim reinará paz e os sofrimentos serão menores. A paciência é o alicerce de um casamento feliz (Anuário das Senhoras, ano xxi, 1954: 120).

Esse caráter paciente, equilibrado, disciplinado está também presente na maneira como a leitora de Feira de utilidades deve cuidar do corpo, mantendo-se sempre bela e elegante. A discursividade da beleza é fortemente investida de equilíbrio e disciplina. É a encarnação da mulher disciplinada, procurando sempre o equilíbrio na maquiagem, nos acessórios, nas roupas. Nas formulações abaixo, podemos observar a materialização de um discurso no qual o corpo da mulher deve ser sempre maquiado e vestido sem exagero e extravagância, obedecendo a seu tipo e personalidade, sendo bonito em qualquer idade:

- A verdadeira arte se ser elegante não está em usar as últimas extravagâncias da moda, exagerar nos enfeites e na pintura, arriscando-se a fazer um triste papel. A mulher verdadeiramente elegante não é nem extravagante, nem 'sofisticada' (Correio da Manhã, 26 de agosto de 1959);

- Muito se tem dito a respeito das roupas. 'O hábito faz o monge', é um provérbio muito antigo e bastante verdadeiro. No entanto, há muitas mulheres que, por 
uma razão ou outra, procuram se vestir em completa oposição ao seu tipo físico e personalidade (Correio da Manhã, 3 de dezembro de 1959);

- Os penteados e as roupas de mocinha, o "make up” exagerado, os concertos "plásticos", tudo isso, apenas torna ridícula a mulher madura. Porque em seus olhos, em seu andar, em seu tom de voz, em todos os pequenos detalhes, que ela não pode prever, a idade revela-se (...) penteados, trajes, tipo de “maquillagem”, gestos tudo nela é harmonioso, gentil e bonito, porque não destoa de sua maturidade (Correio da Manhã, 21 de janeiro de 1960);

- As senhoras de meia idade, cujos cabelos estão embranquecendo, devem evitar chamar a atenção com roupas coloridas e berrantes, impróprias para a sua idade (Correio da Manhã, 6 de fevereiro de 1960);

- Deve haver no toucador duas tonalidades de pó de arroz e duas tonalidades de baton, para serem usados segundo a hora e as cores dos vestidos (Correio da Manhã, 4 de março de 1960);

- Acreditamos que o meio termo, como sempre, é a melhor atitude a tomar, nesse assunto. Nem exageros de pintura, seguindo rigorosamente a moda, nem o desleixo, a falta absoluta de maquilage, deixando descoberto um rosto pálido, em contraste com os radiosos rostos das que se pintam. As mulheres devem se conservar numa atitude de discrição (Correio da Manhã, 5 de agosto de 1960);

- Com uma maquilagem bem feita, os óculos bem escolhidos podem equilibrar e embelezar um rosto (Correio da Manhã, 28 de setembro de 1960);

- Mas cuidado! O exagero é tão pernicioso como a mediocridade. Uma mulher para ser elegante, não precisa torna-se excêntrica. Um ou dois detalhes vistosos numa toilete, podem dar originalidade ao conjunto, mas quando há excesso, surge o perigo do ridículo. As mulheres que se cobrem de ouro, em vez de ofuscante, podem assumir apenas um aspecto vulgar - que é a antítese da elegância (...) Nem tudo que brilha é ouro - nem tampouco elegância (Correio da Manhã, 18 novembro de 1960).

Esse apelo a um corpo bem maquiado, bem vestido, sem excesso e extravagância é condizente com o ethos da imprensa feminina (cena englobante), cujo discurso da beleza procura sempre condenar o exagero. Feira de utilidades, como podemos observar nas formulações acima, dedica espaço privilegiado a essa discursividade que procura validar a mulher que tem controle sobre o seu corpo, que tem personalidade. Mas, ao abordar esse tema, a coluna mostra que a preocupação com a beleza não é desvinculada da arte de conquistar o homem, de agradar os entes 
queridos e amigos, como podemos ver nas formulações abaixo, do texto intitulado $O$ dever da faceirice:

Algumas mulheres, felizmente poucas, relegam a faceirice a um plano secundário,
explicando esse desinteresse como 'superioridade intelectual'. Nada mais falso. A
mulher moderna sabe que, apesar da evolução das ciências e das artes, o homem
continua o mesmo, e o principal atrativo que encontra na mulher é a sua aparência
física. Julgar que porque se casou com ele está dispensada de seduzi-lo é outro grave
erro. O homem é volúvel, sua busca da "mulher ideal” é apenas a forma romântica com
que encobre essa volubilidade, e geralmente envelhecem sem descobrir realmente o que
querem da mulher. Só sabem que a querem. Sempre bonita e renovada, se possível.
Um rosto bonito, uma figura elegante sempre exercem grande poder sobre eles. A
mulher que ama a um deles tem de fazer tudo para prendê-lo, portanto, e esse tudo é a
sedução diária e constante. Eu sei, minha amiga. É cansativo isso, é um pouco tolo, mas
que se há de fazer?
Se o seu marido está acostumado a vê-la despenteada, em chinelas, de roupa desleixada,
sem pintura, aos poucos ele irá esquecendo a figurinha bonita que o atraiu antes, quando
você só lhe aparecia enfeitada e perfumada. Começar a perguntar a si mesmo o que
existe em você, afinal, de interessante... e a resposta é perigosa, minha cara! Por outro
lado, a rua está fervilhando de mulheres bonitas, mais bonitas porque têm a atração do
desconhecido e do proibido. Nenhum homem, numa hora dessas, tem imaginação
bastante para ver, sob as carinhas de boneca encontradas na rua a mesma figura de
mulher em chinelas, despenteada e mal cuidada que ele deixou em casa.
Renan, com grande sabedoria, já dizia: “A mulher, enfeitando-se, sempre um dever; ela
pratica uma arte, arte delicada, que é mesmo, até certo ponto, a mais encantadora das
artes”.
A faceirice é, portanto, obrigação para a mulher. Nem a mulher de negócios, nem a
cientista, nem a mulher de letras, nem a esportista dispensam esse dever primordial para
a conquista do homem. Afinal, podemos pensar deles o que quisermos, mas precisamos
deles para completar a nossa felicidade, não é mesmo? Façamos, portanto, por
conquistá-los (Correio da Manhã, 23 de dezembro 1959).

Na discursividade da coluna, tanto as tarefas domésticas quanto o dever da faceirice são marcas de feminilidade, ou seja, são considerados deveres exclusivamente femininos. Sem esses atributos, a mulher pode comprometer a felicidade conjugal. A leitora da coluna tem por obrigação encarnar esses atributos, pois seu comportamento deve estar sempre associado à mulher ideal que se inscreve na sociedade como boa mãe, boa dona de casa, boa esposa; como uma mulher feminina que sabe seduzir os homens com sua personalidade, beleza e elegância. 
Até o momento, procuramos mostrar o quanto Feira de utilidades está em plena comunhão com a imprensa feminina da época. Sem dúvida, o modo como os temas foram abordados não surpreenderia nenhuma leitora criada nos moldes de uma sociedade burguesa em que a mulher é legitimada positivamente ao assumir seu papel de esposa, mãe e dona de casa. Feira de utilidades reconhece a sua finalidade, que visa a integrar enunciador e destinatário em uma mesma ordem física e social. Por sua própria enunciação, as formulações apresentadas se mostram como um processo de comunicação entre mulheres que incorporam a “verdadeira” essência feminina.

No domínio da memória dessa prática discursiva, mulher é uma palavra que sintetiza, nos anos 50, a moral feminina que se valida através de uma disciplina incessante em ser mãe, esposa e dona de casa. E como acabamos de dizer, Feira de utilidades, no interior dessa imprensa feminina, evoca, acolhe e absorve esses valores. Assim, obedecendo à finalidade dessa imprensa feminina, a coluna apresentava uma diversidade de textos (daí, creio ter surgido o termo feira) cuja finalidade era aconselhar a mulher com dicas úteis para que esta pudesse dirigir melhor o seu lar, cuidando bem dos filhos e maridos, além das dicas de beleza. Essas dicas, por sua vez, procuravam evitar recursos exagerados, vulgares. Dessa forma, a coluna apresentava os mesmos temas presentes na prática textual da imprensa feminina. Na realidade, temas impostos que estão em plena comunhão com essa prática discursiva; ou melhor, são temas que podem aflorar no interior dessa formação ideológica porque não representam perigo, desequilíbrio e desestabilização a essa discursividade.

Mas a imprensa feminina não se valida apenas pelo seu caráter de evocar, acolher e absorver os temas da feminilidade, ela se valida principalmente pelo modo como reconfigura esses temas. É essa reconfiguração que atribui às páginas de revistas e jornais dedicadas à mulher uma maneira de dizer específica, um modo de enunciar que individualiza o modo de existência dessas páginas no campo da imprensa feminina.

Feira de utilidades não é diferente e busca seu modo de existência nesse campo. Pois bem, se, por um lado, a coluna constrói um discurso que limita a mulher à esfera do lar, ou seja, é em relação ao lar que se reconhece, se constitui e se define a mulher, por outro, essa mesma coluna aponta a constituição de uma outra posição da mulher além do lar, como veremos no próximo capítulo. 


\subsection{Feira de utilidades: em “cena” o mídium}

“O debate acerca dos diferentes modos de manifestação do discurso vem ratificar o lugar ocupado pelos dispositivos midiológicos na legitimação de uma obra, reafirmando sua pertinência para uma adequada reflexão sobre a problemática dos enlaçamentos” (Souza-e-Silva, C. P. \& Rocha, D. Apresentação. In: Análise dos textos de comunicação: 17$)$.

Ao considerar os gêneros discursivos como atividades sociais submetidas a um conjunto de condições de êxito, Maingueneau (2000: 68) ressalta a importância da dimensão midiológica dos enunciados, pois, segundo ele, o gênero é inseparável de seu modo de existência material. Dessa forma, o autor olha para o mídium não como um simples “meio" para veicular uma mensagem, isto é, o mídium é algo mais que um simples meio, pois uma mudança do suporte material de um texto modifica radicalmente um gênero discursivo.

Assim como Maingueneau, Marcuschi (2003) nos alerta que devemos dar a devida importância às questões sobre o suporte textual, "mas não no sentido de um meio de transporte ou veículo, nem como um suporte estático e sim como um locus no qual o texto se fixa e que tem repercussão sobre o gênero suportado”. Por isso, analisar o suporte é observar como este contribui para o funcionamento do gênero, “já que o gênero ocorre (surge e se concretiza) numa relação de fatores combinados no contexto emergente” (MARCUSCHI, 2003: 01). Além disso, diria que o suporte nos mostra uma série de fatores ritualizados que servirão para os propósitos da análise do gênero. Tomando o caso de Feira de utilidades, pode-se estabelecer a seguinte cadeia:

A coluna feminina - Feira de utilidades (gênero) $\rightarrow$ Jornal - Correio da Manhã (suporte) $\rightarrow$ Imprensa feminina (cena englobante). 
No caso de Feira de utilidades, seu modo de existência só era possível no segundo caderno do Correio da Manhã, onde circulavam também as seções de arte, cultura e diversão. Não podemos olhar para esse habitat de Feira de utilidades apenas como um ambiente que permite a sua circulação, mas podemos questionar por que Feira de utilidades aparece nesse ambiente e não em outro?

O modo de existência da coluna feminina é ideológico, ou seja, mostra que os assuntos femininos são vistos como amenidades do cotidiano, por isso a coluna feminina divide espaço na página do jornal com colunas sociais e colunas sobre as curiosidades radiofônicas. Esse modo de existência corresponde a uma forma de hierarquia: de um lado, no primeiro caderno, estão as notícias “sérias” que falam de política e economia; do outro lado, no segundo caderno, estão as notícias “amenas” que falam dos acontecimentos do cotidiano (as colunas sociais, as colunas radiofônicas... as colunas femininas etc). Surge, então, a seguinte pergunta: o suporte determina o gênero ou o gênero exige um suporte especial? A resposta para essa pergunta talvez seja a seguinte: o gênero é sempre identificado na relação com o suporte.

Não podemos achar que as questões sobre o mídium estão limitadas à problemática do suporte. Mídium não é suporte. Mídium é um modo de manifestação do discurso. Parafraseando Hamlet, eu diria: "há mais coisa entre o mídium e o discurso do que sonha a nossa vã análise do discurso”.

Além do suporte, a oposição entre oral e escrito é uma outra categoria midiológica que merece destaque, principalmente na imprensa feminina. Se pensássemos nessa oposição de forma estanque, referindo-se aos suportes físicos, teríamos: de um lado, uma forma de produção textual-discursiva para fins comunicativos por sua constituição sonora; de outro lado, um modo de produção textual-discursiva para fins comunicativos por sua constituição gráfica.

Pensando essa oposição além do suporte físico, do seu meio de produção, observaremos que a concepção discursiva do enunciado em oral ou escrito não se funda de modo dicotômico, mas é uma relação que se estabelece num continuum. Em razão desse continuum, os enunciados por vezes constituem domínios mistos, como é o caso dos enunciados de Feira de utilidades.

Não podemos, então, achar que os enunciados orais envolvem enunciados estritamente dependentes do ambiente e os enunciados escritos, enunciados estritamente 
independentes do ambiente. Há enunciados, que mesmo independentes do ambiente, se aproximam do estilo falado. Como disse acima, essa relação deve se estabelecer num continuum, pois o locutor de um texto pode jogar com essa distinção, como é o caso do excerto abaixo:

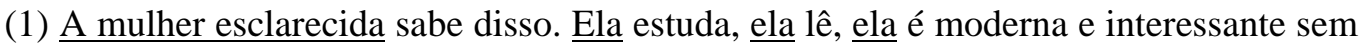
perder seus atributos de mulher, esposa e mãe. Não tem necessariamente de trazer um diploma e um título, mas conhece alguma coisa mais além do seu tricô, dos seus quitutes e dos seus bate-papos com as vizinhas. Ela cultiva, especialmente, a sua capacidade de ser compreensiva e humana. Tem coração. Despoja-se do sentimentalismo barato e inútil, e aplica sabiamente a sua bondade e a sua ternura. É mulher.

(2) Você, minha leitora, não limite o seu interesse à arte de embelezar-se, de ser elegante, de atrair os olhares masculinos. A futilidade é fraqueza superada pela mulher esclarecida. E você é uma “mulher esclarecida”, não é mesmo? (Correio da Manhã, 21 de agosto de 1959).

Esse texto publicado em Feira de utilidades é destinado a ser lido. As formulações em (1), construídas em terceira pessoa, parecem ignorar seu alocutário que não se encontra no mesmo espaço físico que o locutor. Não há formulas fáticas e nem componentes embreantes que estejam em relação com a situação de enunciação. Ou seja, a construção dessas formulações não está ligada ao ambiente espaço-temporal imediato. Estamos diante de um enunciado escrito de estilo escrito, construindo um sistema de referência intratextual (mulher esclarecida, ela, seu(s), sua). No entanto, as formulações em (2) estão ligadas ao ambiente partilhado pelo locutor e alocutário: há componentes embreantes (característicos do estilo falado) que estão em relação de dependência com o ambiente (você, minha), além de elementos fáticos (não é mesmo?). São enunciados escritos de estilo falado que encenam a conversa entre duas amigas. Trata-se de dar à leitora a sensação imediata de que ela é uma mulher esclarecida. Esse estilo de enunciados é decorrente da natureza da relação entre os interlocutores.

É, então, característico dos textos publicados na imprensa feminina: a marcação das pessoas envolvidas no ato de enunciação (eu/tu); o uso do modo imperativo, não para ordenar, mas para aconselhar; a utilização de uma pontuação mais exclamativa e interrogativa. Esse estilo de enunciados autoriza o emprego desses traços, a fim de 
estabelecer uma identificação entre os sujeitos envolvidos no ato de comunicação. Segundo Buitoni (1981: 125),

O texto da imprensa feminina sempre vai procurar dirigir à leitora, como se estivesse conversando com ela, servindo-se de uma intimidade de amiga. Esse jeito coloquial, que elimina a distância, que faz as idéias parecerem simples, cotidianas, frutos do bom senso, ajuda a passar conceitos, cristalizar opiniões, tudo de um modo tão natural que praticamente não há defesa.

O excerto acima reflete também o quanto o enunciador faz uso da função conativa a fim de tornar envolvente o texto dedicado a seu destinatário, a mulher. Para Jakobson (1995: 125),

A orientação para o destinatário encontra sua expressão gramatical mais pura no vocativo e no imperativo (...). As sentenças imperativas diferem fundamentalmente das sentenças declarativas: estas podem e aquelas não podem ser submetidas à prova de verdade.

A predominância da função conativa legitima o dizer de Feira de utilidades cuja finalidade comunicativa pode ser traduzida pela modalização "saber fazer”, o que caracteriza o ethos conselheiro dessa prática discursiva.

Refletir sobre o ato de aconselhar nos permite descrevê-lo como sendo um ato em que o destinador (A) se dirige ao destinatário (B) para aconselhar sobre algo que podemos chamar de referente (R). Numa perspectiva discursiva, teríamos o seguinte quadro:

(A) fala assim por que (B) espera que (A) lhe fale dessa forma sobre (R);

(A) é, então, autorizado pela esfera de comunicação verbal a aconselhar (B), enquanto (B) crê em (A) ao aconselhar (R);

Para realizar tal conselho, (A) precisa se fazer valer de uma corporalidade "conselheira”, validada pela modalização "saber fazer”, para se dirigir a (B) que deseja "saber fazer". 
Frente a esse quadro, para validar o tom conselheiro, (A) ao se dirigir a (B) busca sempre uma identificação através do você, minha amiga. Em suma, o ato de aconselhar perpassa todos os textos inseridos na coluna, ou melhor, o ato de aconselhar está associado a essa prática discursiva institucional que é caracterizada pela cena englobante - a imprensa feminina.

\subsection{Análise de uma coluna em "cena”: da cena genérica à cenografia}

Antes de tudo, gostaríamos de esclarecer o subtítulo. Ao dizer da cena genérica à cenografia, não estamos pensando num procedimento que se dá sob dois planos distintos, ou seja, não estamos pensando na cena genérica dissociada de sua cenografia. Temos por princípio um procedimento que se funda sob uma perspectiva "global” da cena da enunciação, que não privilegia nem a cena genérica nem a cenografia, mas integra-as. Nessa perspectiva, conforme abordamos no capítulo Gêneros do discurso: construção e reconfiguração na $A D$, acreditamos que o texto, ao ser encenado, seja interpelado por três cenas: a cena englobante e a cena genérica que, juntas, definem o quadro cênico do texto, e a cenografia que legitima o que o discurso pretende instituir, ou melhor, "a cenografia é ao mesmo tempo a fonte do discurso e aquilo que ele engendra” (MAINGUENEAU, 2000: 87).

Adotando esse aparato teórico-metodológico, podemos dizer desde já que a leitora de Feira de utilidades se encontra envolvida nessas três cenas, pois, ao se deparar com a coluna, a leitora a recebe como um enunciado da imprensa feminina. Nessa esfera de circulação, a leitora é, então, interpelada como uma mulher que deseja ser aconselhada.

IMPRENSA FEMININA - tem em vista um público feminino (cena englobante)

COLUNA FEMININA - aconselha a mulher dona de casa, mãe e esposa (cena genérica)

FEIRA DE UTILIDADES - dita “novos” padrões visando à constituição de uma mulher esclarecida (cenografia) 
Partimos desse esquema "global" para analisar a coluna publicada em 24 de fevereiro de 1960. Com relação ao procedimento de análise, gostaríamos de esclarecer que procuramos seguir o modo como os textos estão dispostos na coluna: em espaço vertical, lemos o texto de cima para baixo e da esquerda para direita. Esse procedimento está embasado na hipótese de que o modo como a fala é encenada em Feira de utilidades vai sendo construído progressivamente por intermédio seqüencial dos textos que a coluna engendra.

Pensando no estatuto de Feira de utilidades, acreditamos que a coluna feminina, assim como os gêneros publicitários, pode ser classificada como um gênero instituído de modo III porque, embora possua um formato estável, não apresenta uma cenografia preferencial. A nosso ver, esse modo de genericidade se deve justamente à sua instância autoral que prevalece sobre a instância rotineira.

Não podemos perder de vista que essa instância autoral está associada ao efeito de inovação construído pela imprensa feminina, pois, embora o estatuto genérico estabilizado de Feira de utilidades seja o de um manual de como se comportar, agir, cuidar dos filhos, cuidar de si etc., o modo como cada coluna encena sua fala procura sempre uma cenografia diferenciada. Ou melhor, em vez de se contentar em manter o status quo através de uma cena genérica em que o enunciador procura apenas aconselhar seu enunciatário, Feira de utilidades desenvolve uma cenografia que visa reformular o status quo, pois a leitora da coluna não é simplesmente aconselhada a usar a última moda, mas aconselhada a questionar de modo esclarecido se deve ou não usar a última moda. Dessa forma, Feira de utilidades procura validar, através da sua discursividade, a imagem da mulher esclarecida.

Ao procurar validar a discursividade da mulher esclarecida, ao reformular o status quo, a coluna procura inovar sua cenografia em relação a uma cenografia tradicional veiculada pela imprensa feminina dos anos 50. Como dissemos acima, esse efeito de inovação é constitutivo da imprensa feminina. Segundo Buitoni, esse caráter inovador não pode ser entendido como revolucionário, crítico, conscientizador, mas como um novo que se organiza na aparência, na superfície. Para defender essa tese, Buitoni (1981: 130) diz: "se a imprensa feminina nasceu do veículo de difusão de moda, dificilmente se afastaria desse novo, razão de ser seu assunto principal. E o novo acabou contaminando qualquer conteúdo que fosse incluído em páginas dedicadas à mulher”. No interior dessa prática, vejamos como Feira de utilidades, buscando se assemelhar ao 
ritmo de vida atual, se "renova", trazendo assuntos variados que mostram o caráter esclarecido de seu enunciador.

Neste momento do percurso analítico, nossa preocupação é definir a cena genérica “coluna feminina”, para, num segundo momento, estabelecer a relação dessa cena com a cenografia engendrada.

\section{a) Sobre o enquadramento espaço-temporal e o peritexto}

Representando o Correio Feminino, $5^{\circ}$ caderno que era publicado aos domingos, a coluna, em espaço vertical, apresentava cerca de treze textos (eram diversos os gêneros de discurso inseridos na coluna: editorial, quadrinhos, citação, receita) por publicação. Essa periodicidade, por sua vez, exige do gênero certas regularidades ligadas ao seu peritexto ${ }^{22}$. Partindo da perspectiva teórica de Adam (1997), podemos dizer que a descrição do peritexto permite depreender a unidade do gênero, isto é, o seu caráter rotineiro. Ao abordar essa questão, o autor propõe a seguinte classificação para o peritexto jornalístico:

\begin{tabular}{|c|c|c|}
\hline Peritexto do jornal & \multicolumn{2}{|c|}{ Peritexto do artigo } \\
\hline 1 Nome do iornal & Verbal & Iconográfico \\
\hline 2. Indicação de rubrica & $\begin{array}{l}\text { 3. "título acima" } \\
\text { 4. "título" } \\
\text { 5. "subtítulo" } \\
\text { 6. "Lead" } \\
\text { 7. "Intertítulo" }\end{array}$ & $\begin{array}{ll}\text { 8. } & \text { Ilustração } \\
\text { 9. } & \text { Legenda }\end{array}$ \\
\hline
\end{tabular}

Partindo desse quadro proposto por Adam, ao descrever o peritexto da coluna, observamos a seguinte divisão: na parte superior da coluna o título Correio Feminino, que indica a seção feminina do jornal, fazendo referência ao $5^{\circ}$ caderno que era publicado todos os domingos; na segunda linha abaixo, lê-se um sub-título Feira de utilidades, e, em seguida, alinhado à direita, o nome da colunista Helen Palmer. Diante dessa descrição, propomos o seguinte quadro:

\footnotetext{
${ }^{22}$ São os elementos externos (e técnicos) regularizadores do texto, ou melhor, são elementos de ordem paralingüística.
} 


\begin{tabular}{|l|l|}
\hline Peritexto do jornal & Peritexto da coluna \\
\hline & Título \\
Nome do jornal & Sub-título \\
Data de publicação & Nome da colunista \\
Página & \\
Indicação de rubrica & \\
\hline
\end{tabular}

Resumindo, as condições de emprego da coluna são, de um certo modo, estabilizadas. Esse caráter estabilizado se deve justamente ao seu modo estável de produção; no entanto, seu modo de consumo apresenta uma certa instabilidade, pois a maneira como os textos são produzidos propõe, pelo menos, dois tipos de leitura: com títulos chamativos, a leitora pode condensar sua leitura somente aos textos que lhe interessam; por outro lado, a leitora chamada a ser esclarecida/inteligente não faz uma leitura condensada, mas totalizadora.

b) Finalidade e estatuto dos participantes

Como gênero da imprensa feminina, há uma fixidez dos papéis: envolvendo um locutário mulher e um alocutário mulher, que, geralmente, fazem parte da mesma comunidade imaginária. Dirige-se a um público feminino situado no espaço urbano e pertencente às classes média e alta. Assim como o texto publicitário, o texto da imprensa feminina visa seduzir para aconselhar sua leitora a agir de modo esclarecido e inteligente (fazer fazer), ou seja, a coluna feminina se caracteriza pelo seu compromisso em aconselhar a sua leitora a "fazer fazer”. Mas não podemos esquecer que, em Feira de utilidades, o ato de aconselhar visava também à venda dos produtos cosméticos da Pond's.

\section{c) Organização textual}

Tomando como base o ato de aconselhar como constitutivo dessa prática, podemos observar dois tipos de conselho: os diretos e os indiretos. O que os caracteriza é justamente a materialização das formulações lingüísticas. Os diretos seriam os 
enunciados que marcam explicitamente ou implicitamente o seu destinatário, ou seja, o "tu”. Por exemplo:

1) Se você deseja conservar sua silhueta fina e esbelta, não abuse dos doces, chocolates e sorvetes. Prefira as frutas à sobremesa;

2) Se você possui mãos pequenas, não use anéis com pedras exageradas, pois estas só ficam bem nas mãos grandes, de dedos longos;

3) Lave o rosto pelo menos duas vezes por dia e complete a higiene de sua cutis com um creme de limpeza que penetre fundo nos poros e os desobstrua;

4) Para proteger a sua roupa de lã contra as traças use bórax em pó.

Os termos sublinhados marcam a ancoragem do sujeito na linguagem. No que diz respeito ao ato de aconselhar, é preciso que no processo discursivo o seu destinatário esteja com seu território bem marcado. O “eu”, na realidade, busca autoridade no seu dizer para demarcar seu espaço de conselheiro. No caso dos enunciados acima, podemos observar como o destinatário ora é marcado explicitamente pela forma pronominal você, ora de forma implícita por meio dos pronomes seu, sua e das formas verbais que caracterizam o modo imperativo lave, use, abuse, etc.

Já os conselhos indiretos, seriam aqueles marcados pela não-pessoa “ele”. Por exemplo:

5) Os homens apreciam sempre as mãos delicadas e claras de uma mulher;

6) A esposa, com seu amor e capacidade de organização, pode ajudar o marido a subir na vida, fazendo com que ele ganhe mais confiança em si;

7) Todos os especialistas de beleza são acordes de que o tratamento básico para qualquer tipo de pele é apenas: água e sabão.

Se levássemos em conta apenas as formas lingüísticas que entram na enunciação, certamente diríamos que se trata apenas do objeto do discurso. Mas olhando para os elementos não verbais da situação, ou seja, para o estatuto do enunciador e do destinatário, podemos dizer que, no interior dessa prática discursiva, o que a caracteriza é o tom conselheiro; nesses enunciados há sempre um “eu” falando a um “tu”. Vejamos como as estratégias são diversas, mas a significação dos enunciados é a mesma. Dessa 
forma, a leitura dos enunciados acima implica o seguinte sentido: (5) você deve ter mãos delicadas e claras; (6) você, com seu amor e capacidade de organização (...); (7) você deve limpar a pele com água e sabão. Observemos que a significação não está na palavra, mas na compreensão dialógica que valida o ato de aconselhar, além do acento apreciativo (de conselho) que essa prática atribui ao enunciado. Alguns elementos lingüísticos ajudam a legitimar esse acento, vejamos:

No enunciado 5, o substantivo "homem" representa o objeto de desejo da mulher no saber dessa formação discursiva, logo o enunciador, ao realizar tal estratégia, não quer apenas constatar um fato, mas mostrar ao seu destinatário o que este pode fazer para conseguir tal objeto de desejo, uma vez que esse homem aprecia esse fazer;

No enunciado 6, se pensamos em um efeito parafrástico, diríamos que esposa poderia ser substituída por mulher ou por você, pois o destinatário dessa coluna é a própria mulher/esposa e não o homem, isto é, o destinatário no dizer desse discurso ocupa essa posição sujeito;

No enunciado 7, o conselho se dá via outrem, ou seja, através de todos os especialistas cuja autoridade permite ao enunciador validar seu dizer para dialogar com sua leitora.

Observamos, também, que as orações subordinadas condicionais (enunciados 1 e 2) e finais (enunciado 4) marcam uma seqüência sintática típica desse discurso. Ou seja, essas seqüências ajudam a dar o tom conselheiro que caracteriza a coluna. Diante desse quadro, arriscaria dizer que as seqüências típicas são:

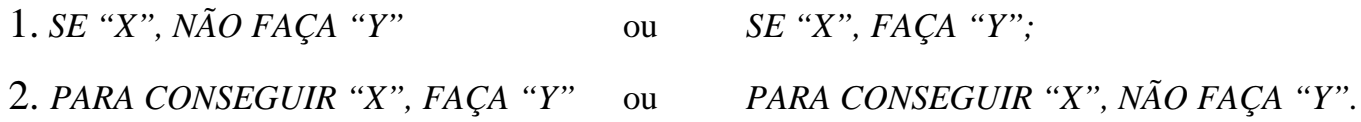

Vejamos que, em ambos os casos, a negação aparece marcada na prótase e nunca na apódose, pois é sobre aquele enunciado que recai o tema da enunciação; é ele que valida o tom conselheiro. Com relação à apódose, chegamos à seguinte explicação: 
quando o enunciado apresenta uma condição, " $X$ ” pode ser preenchido por verbos factuais (ter, desejar, possuir); caso o enunciado sugira finalidade, "X” será preenchido exclusivamente por verbos implicativos (proteger). Mas, independentemente do seu teor de condição ou do seu teor de finalidade, o efeito de sentido do enunciado é levar o destinatário a “fazer-fazer”. Com isso, é possível verificar como a construção sintática valida o modo de argumentar, ou melhor, o modo de enunciar.

d) Sobre a cenografia

Dirigir um lar; Para renovar o seu guarda-chuva; Se você emagrecer de repente...; Toda pele precisa de nutrição; Gordura... esse fantasma!; Dois bons hábitos; Para servir a mesa; Compota de abacaxi; Pudor nos pés. Esses foram os títulos dos textos publicados em 24 de fevereiro de 1960. Além dessa materialidade lingüística, a coluna publicava a seguinte materialidade pictórica: uma foto de uma mulher trajando um interessante conjunto de saia pregueada e jaqueta e um quadrinho cuja personagem feminina chamada Amélia relata seu problema (- Já servi damasco gelado e quente, não sei o que fazer mais para variar). 


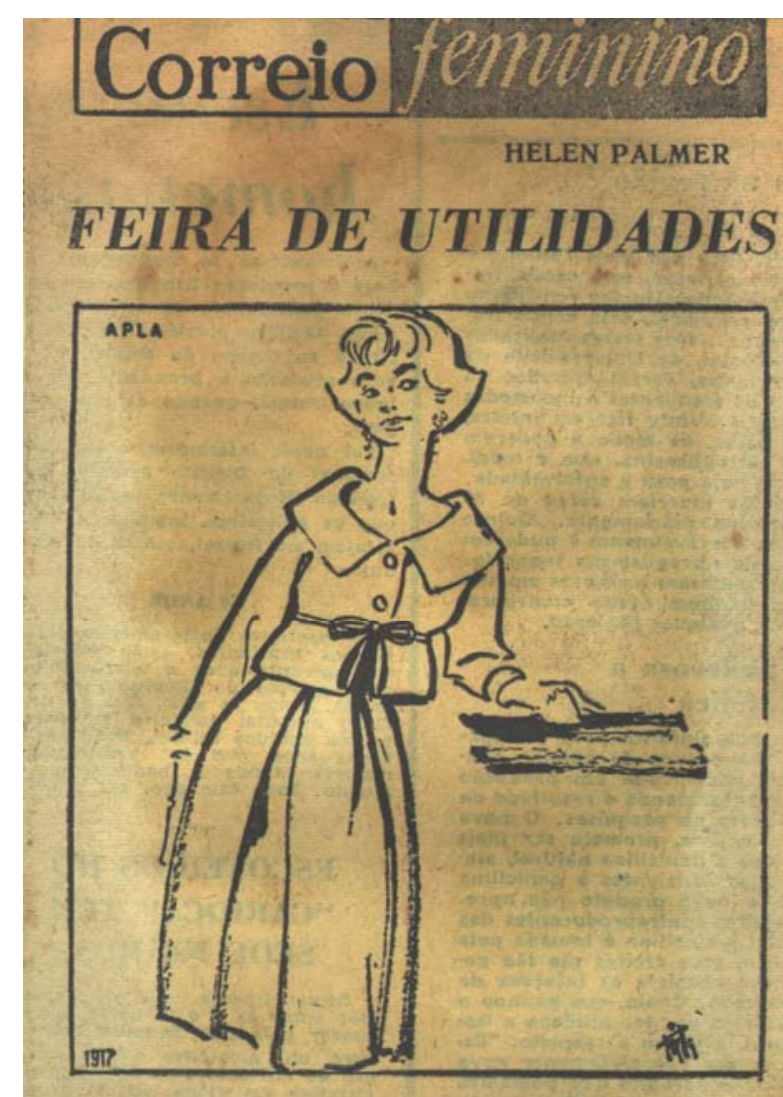

Interessante conjunto de saia pregueada e jaqueta.

\section{DIRIGIR UM LAR}

Sómente uma mulher, e dons de casa, sabe e reconhece a grande tarefa que é bem diristr uma casa. A dona de casa tem de ser, antes de tudo, uma economista, uma "equilibrista" das finanças, principalmente com as dificuldades da vida atual, o lar $b$ o lugar onde devemos encontrar a nossa paz de espirito num ambiente
limpo, sadio e agradável e cabe a multher providenclar isso. Muitas limpo, sadio e agradável e cabe à mulher providenclar isso. Muitas liberdade para o marido fuma vitrina permanente, onde nao ha brincar. Essas, geralmente, fazem da vida do lar um inferno guase sempre obrigam o marido a ir procurar confôrto e bem-estar quase lugar, quando náo nos bracos de outra mulher, sem-estar noutro - desleixo e a falta de limpeza tornem a sua casa um lusar impossivel de se viver, náo caia também no exaséro de exigir gue sens filhos e seu marido sacrifiquem o proprio contorto para nko desarranjar a "exposiçáo" que é o seu lar. Mutas vêzes, um eachlmbo toringiedo largado no tapéte, umas almofadas com a marca de uma cabega que nelas descansou dás A economia

com sabedoria: nem um bibeló, náo troque ja as cortinas da sala de menos. Sacrifique bons e fartos cardápios na sua mesa. Nắo sirva uísque is visitas, mas de bastante frutas a seus rinhos, frutas boas, eseolhidas, nao as já meio passadas e as vêzes passadas demals, que diversas donas

de casa costumam comprar por aisuns tostoes a menos.

as relar pelo dinheiro de seu marido funcáo delas e quem tem de a que sabe dar ordens e acompanha de perto a sua execucso. casa que mantém a limpeza, $a$ ordem, o capricho em sua casa, sem fazer desta um eterno local de cerimónias, de deveres, onde tudo 6 proibido. B' $^{\prime}$ a que laz de sua casa o lugar de descanso de felleidade do marido e dos filhos, onde eles se sentem reaimente bem, a vontade, e sfo bem tratados, o melhor lugar do mundo,

\section{PARA RENOVAR O SEU} GUARDA-CHUVA

Prepare uma mistura de $1 / 3$ xieara de chá forte e 2 colheres chuva para reavivar-line cór do tecldo e fixá-la. 


\section{TOODA PELE PRECISA \\ DE NUTRIÇÃO}

E para isso existem os cremes. Se você deixa a sua pele sem cuidados, ela vai perdendo a umidade, ressecando, envelhecendo. Para casos assim, existem agora uns cremes especiais, acrescidos de uma nova substância - alantoina - que é, segundo os téenicos, uma raiz medicinal de surpreendentes virtudes rejuvenescedoras. Esses produtos restauram o teor de umidade necessário à pele, destruindo as camadas ressequidas. Se a sua pele tem tendência a pele sêca, aconselho-a a experimentar um dêsses cremes, a fim de preservar a juventude de seu rosto, pois nada envelhece mais do que uma pele riscada pelas rugas, pelos "pés-de-galinha" e pelos sulcos.

$$
\text { *** } *
$$

"As rugas da velhice deveriam ser apenas os vestígios dos sorrisos da Juventude."

$$
* * *
$$

\section{DOIS BONS HABITOS}

Se você acostumar-se a dar. diàriamente, um passeio a pé, inspirando profundamente pelo nariz e expirando lentamente. esvaziando ao máximo os pulmōes, ou fazer exercício pulando corda, todos os dias, você estará trabalhando para manter em forma os seus pulmôes.

$$
\text { *** }
$$

COMPOTA DE ABACAXI

Descasque um abacaxi, limpe-os dos "olhos" c corte em pedaços não muito grandes. Faça uma calda: 1 xicara de águs para 1 xicara de açúcar - deite dentro os pedaços de abacax até ferver, coloque-os então em vidros próprios, feche e deixe-os em banho-maria por 20 minutos

$$
\text { *** * }
$$

IA. SERVI VAMASCO SELADO E QUENTE. NAO SEIO

QUE FAEER MAIS PARA VARIAR.

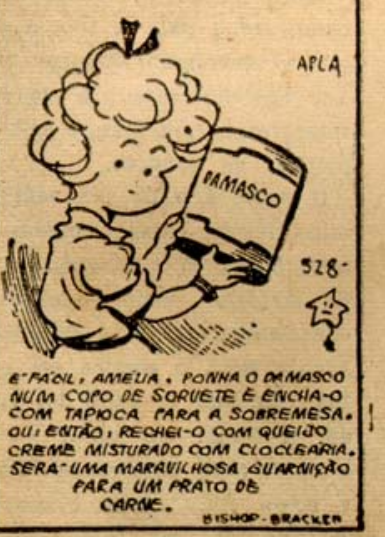

\section{GORDURA ... ESSE}

\section{FANTASMA!}

Se você ingere grande quantidade de gorduras, estas se acumularăo em certas partes do seu corpo, como o ventre $e$ as cadeiras. Os doces e as féculas geralmente provocam a gordura distribuida pris uniformemciura d rosto e no abdome, ficando com as pernas magras. De qualquer forma, a gordura é horrorosa $e$ deve ser evitada sempre. Se você notar que a balança acusá aumento progressivo de péso, siga uma dieta racional Se siga uma dieta racional. Se médico para ver como anda seu metabolismo.

$$
* * *
$$

\section{PARA SERVIR A MESA}

Para $_{2}$ o almôço, café ou lanche, você pode usar toalhas de côres alegres, xadrezes ou panicôres alegres, xadrezes ou pani, mas, para o Jantar, a toalha deve ser sempre branca. Por baixo das toalhas, use uma proteçāo para a mesa, de flanela ou outro tecido grosso. Se usar o serviço americano individual, use descansa-pratos.

$$
\text { *** * }
$$

"Seja generosa, leal, bondosa e firme em seus gestos e atitudes. Esses sentimentos transparecerão em seu rosto $e$ atrairẫo a simpatia de todos que a cercam."

TERRY HUNT

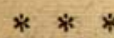

\section{PUDOR NOS PES!}

Existem certos lugares na Ásia Central onde se uma mulher passar deixando ver os pés, as senhoras honestas coram visenm o rosto como se estivessem ram o rosto como se estivessem vendo a ultima das inconveniências. Na China, até algum tempo atrás, falar em pés femininos era obcenidade nenhum pintor mostrava os pés das figuras femininas de sens modelos. Na Espanha, no fim do século XVII, as roupas eram loculo xvil, as roupas eram longas, arrastavam-se pelo chăo, escondendo os pés. E quando a rainha Luiza de Saboia, mulher de Fellpe V, mandou as mulheres encurtarem as saias alguns centimetros a fim de năo levantar tanta poeira quando passavam, muitos maridos declaravam, muitos maridos declararam que preferiam suas esposas mortas que expostas a tal "despudor". Como mudam os tempos! 
A leitura dos subtítulos permite arriscar a seguinte análise: a coluna cumpre sua finalidade rotineira e sua cena enunciativa, limita-se apenas ao quadro cênico do texto. No caso da coluna feminina, os títulos são formas que colocam os textos em confluência com a sua cena genérica, pois, ao ler compota de abacaxi, a leitora sabe que se trata do gênero receita; ao ler toda pele precisa de nutrição, a leitora sabe que se trata de uma dica de beleza. Dessa forma, os títulos permitem à leitora fazer uma leitura mais focada no seu objetivo, ou seja, estou lendo essa coluna à procura de uma receita ou estou lendo essa coluna à procura de alguma dica sobre como tratar das minhas rugas. Mas isso só acontece pela competência genérica da leitora que não precisa ler todo o enunciado para saber se o texto trata de uma receita ou de uma dica de beleza. Nesse sentido, o título já permite estabelecer a relação com o gênero textual.

Essa relação é chamada por Genette de arquitextualidade, uma vez que “define a relação de pertencimento de um texto a um gênero, a qual orienta e determina $o$ horizonte de expectativa do leitor e, portanto, a sua recepção” (apud Grillo, 2005: 94). Em suma, os títulos dos textos caracterizam a finalidade que a coluna deseja colocar em destaque em consonância com o seu estatuto genérico. Dessa forma, mantém-se o status quo e a leitora se confronta diretamente com o quadro cênico de uma "grande” receita. Esse é um comportamento inerente ao gênero.

Mas se o percurso de leitura da coluna é totalizador, o enunciatário certamente se confrontará com um outro cenário, um cenário que reformula o status quo projetando no discurso a imagem da dona de casa "esclarecida" que sabe e reconhece a grande tarefa que é bem dirigir uma casa.

Essa enunciação se caracteriza não pela escolha dos temas, mas pelo modo como são apresentados. Para mostrar esse cenário, o nosso processo de análise faz o seguinte percurso de leitura: de cima para baixo e da esquerda para direita.

Logo abaixo do título Correio Feminino, do subtítulo Feira de utilidades e do nome do autor da coluna Helen Palmer, aparece a foto (desenho) de uma mulher, em pé, com o corpo ligeiramente inclinado para esquerda, apoiando o braço esquerdo sobre um aparato qualquer. Seu rosto ligeiramente inclinado para direita com um olhar voltado para sua esquerda.

Toda essa postura mostra uma mulher elegante vestindo um interessante conjunto de saia pregueada e jaqueta (legenda da foto). A roupa, como extensão do 
corpo, qualifica a mulher que a veste. Sendo a roupa interessante, a mulher que a porta também o é.

Nessa relação entre materialidade pictórica (foto/desenho) e materialidade lingüística (legenda), depreende-se a simbiose do corpo e do caráter entre enunciador e enunciatário. A leitora-modelo dessa coluna é a própria mulher trajando esse modelo; é a mulher que sabe conduzir suas tarefas domésticas, que sabe dirigir um lar.

A foto instaura um diálogo com o texto a seguir (dirigir um lar). A mulher que habita o lar caracterizado pelo enunciado do texto é a mulher interessante da foto. Além da roupa, ela é interessante porque sabe dar o “calor” necessário ao verdadeiro lar.

A nosso ver, essa mulher dona de casa interessante é uma extensão da mulher esclarecida que veremos no próximo capítulo. O que nos leva a realizar tal aproximação não é simplesmente a relação dialógica entre as colunas, mas o modo como se dá a progressão textual. Alguns dos verbos e advérbios que aparecem são do campo semântico do saber/do intelecto, como podemos observar em alguns excertos:

- Somente uma mulher, e dona de casa, sabe e reconhece a grande tarefa que é bem dirigir uma casa;

- A economia é outro problema que a mulher tem de resolver com sabedoria: nem gastar de mais, nem de menos;

- A boa dona de casa é a que sabe dar ordens e acompanhar de perto a sua execução.

As condições de enunciação vinculadas a esse texto, além de definir as condições de enunciador e de enunciatário, definem também o espaço (topografia) e o tempo (cronografia) a partir dos quais se desenvolve a enunciação. É no âmbito do lar que a coluna encena o discurso da mulher interessante e esclarecida.

O texto dirigir um lar se desenvolve através da cronografia das dificuldades do tempo atual. Para encenar esse tempo atual, o texto é construído predominantemente em tempo presente, marcando uma concomitância com o momento da enunciação que sugere uma concomitância com os acontecimentos da sociedade em que a mulher está inserida. Nesse sentido, “poderíamos dizer que o que marca a coincidência, nesse caso, é o englobamento do momento da enunciação pelo momento de referência. O que há 
sempre é uma coincidência entre o momento do acontecimento e o momento de referência” (FIORIN, 1999: 149).

Para Fiorin (1999), pode-se elencar três casos de tempo presente na relação entre momento de referência (MR) e momento de enunciação (ME). Primeiro, o presente pontual, que define a coincidência entre MR e ME, ou seja, "como o momento de referenciação é um momento preciso, há coincidência entre ele e o momento da enunciação” (p.149). Segundo, o presente durativo, que define um momento de referência mais longo do que o momento de enunciação. Terceiro, o presente omnitemporal ou gnômico, que define o momento de referência e o momento de acontecimento como ilimitado. É importante ressaltar que Fiorin organiza esse sistema temporal repartindo-o em tempos enunciativos e enuncivos.

Partindo dessa classificação, podemos dizer que os tempos verbais de dirigir um lar não se organizam em torno de um presente pontual, pois não se trata de um estado que ocorre no momento de referência presente, um atual, que se passa no agora dia 24 de fevereiro de 1960. Acreditamos, então, que os tempos verbais de dirigir um lar se organizam num jogo entre presente durativo e presente gnômico. Por quê?

O presente durativo tem como momento de referência a vida atual, momento mais longo que o agora, é na realidade o tempo dos acontecimentos atuais, mas, em algum momento, é simultâneo ao momento de enunciação, quando encena a dona de casa cuidando do lar, procurando colocar um cachimbo do marido e o brinquedo do filho nos seus lugares. É na realidade um momento de dinamicidade do texto, que valida a encenação de uma dona de casa dirigindo seu lar, ou seja, o enunciador não diz apenas como dirigir um lar, ele mostra como dirigir um lar, como podemos observar no excerto abaixo:

Somente uma mulher, e dona de casa, sabe e reconhece a grande tarefa que é bem dirigir uma casa. A dona de casa tem de ser, antes de tudo, uma economista, uma "equilibrista" das finanças, principalmente com as dificuldades da vida atual. O lar é o lugar onde devemos encontrar a nossa paz de espírito num ambiente limpo, sadio e agradável e cabe à mulher providenciar isso. Muitas erram ao fazer de sua casa uma vitrina permanente, onde não há liberdade para o marido fumar o seu cachimbo, para o filhinho brincar. Essas, geralmente, fazem da vida do lar um inferno e quase sempre obrigam o marido a ir procurar conforto e bem estar noutro lugar, quando não nos braços de outra 
mulher. Sem permitir que o desleixo e a falta de limpeza tornem a sua casa um lugar impossível de se viver, não caia também no exagero de exigir que seus filhos e seu marido sacrifiquem o próprio conforto para não desarranjar a exposição que é o seu lar. Muitas vezes, um cachimbo esquecido sobre o aparador, um brinquedo largado no tapete, umas almofadas com a marca de uma cabeça que nelas descansou dão o "calor" necessário ao verdadeiro lar.

O presente gnômico é utilizado justamente para enunciar as verdades dessa vida atual. O enunciado procura instaurar verdades incontestáveis que se pretendem como verdades eternas, pois, segundo Fiorin, como o momento do estado (“é”) coincide com o momento de referência, há um sempre implícito. Vejamos os excertos abaixo:

- $\quad$ Somente uma mulher, e dona de casa, sabe e reconhece a grande tarefa que é bem dirigir uma casa;

- O lar é o lugar onde devemos encontrar a nossa paz de espírito num ambiente limpo, sadio e agradável e cabe à mulher providenciar isso;

- A economia é outro problema que a mulher tem de resolver com sabedoria: nem gastar de mais, nem de menos;

- A boa dona de casa é a que sabe dar ordens e acompanhar de perto a sua execução. É a que mantém a limpeza, a ordem, o capricho em sua casa, sem fazer desta um eterno local de cerimônias, de deveres, onde tudo é proibido. $\underline{E}$ a que faz de sua casa o lugar de descanso de felicidade do marido e dos filhos, onde eles se sentem realmente bem, à vontade, e são bem tratados.

As estratégias descritas acima, a nosso ver, ao mesmo tempo em que dão uma sensação de aproximação com a leitora, permitem também um afastamento. Esse afastamento se deve à predominância de formulações construídas na terceira pessoa do tempo presente. Enunciador e enunciatário não estão no mesmo plano, uma vez que o enunciador pretende fazer um julgamento do que é uma boa dona de casa.

O texto em questão não é empregado para ser consumido da mesma forma que uma receita culinária ou uma dica de beleza. Ele é empregado para ser consumido 
como um “editorial” da coluna, pois, ao desenvolver, na progressão textual, a avaliação do bem dirigir uma casa, o enunciador inscrito no enunciado, uma mulher interessante e esclarecida, sabe como forjar um simulacro de distanciamento do eu que fala em relação ao tu com quem fala. Segundo Discini (2003, 159), “o discurso do editorial orienta-se sintaticamente para representar a não-pessoa, ele”.

Ainda com relação ao texto de abertura, o enunciador cria um simulacro do saber dirigir um lar. Esse simulacro da sabedoria está associado ao modo como a mulher deve dirigir o lar, que é controlado por uma operação de "harmonização” gerada pelos “equilíbrios” dos seus atos. Ou seja, o “calor” necessário ao verdadeiro lar só é alcançado com equilíbrio, que significa nem o desleixo e a falta de limpeza, nem o exagero ao fazer do lar uma vitrina permanente.

O sentido das palavras “ordem”, “agradável”, “liberdade” é regido pelo princípio do “equilíbrio”, enquanto o sentido da “desordem”, do “desagradável”, da “não liberdade” é regido pelo princípio do “desequilíbrio”, apontado pelas palavras desleixo, falta e exagero. É, então, essa competência discursiva que rege a semântica global do discurso da mulher esclarecida que veremos no próximo capítulo, ou seja, é essa competência que leva o enunciador a fazer suas seleções lexicais para validar a imagem da mulher esclarecida.

Não estamos dizendo, com isso, que esse discurso possui um léxico que lhe é próprio, mas que o sistema de coerção restringe o universo lexical que o enunciador será levado a utilizar para marcar sua posição no campo discursivo (Maingueneau, 1984). É importante dar um tratamento semântico no caso do léxico, pois como exprime Pêcheux (1997: 160)

O sentido de uma palavra, de uma expressão, de uma proposição, etc., não existe “em si mesmo” (isto é, em sua relação transparente com a literalidade do significante), mas, ao contrário, é determinado pelas posições ideológicas que estão em jogo no processo sóciohistórico no qual as palavras, expressões e proposições são produzidas (isto é, reproduzidas).

O “equilíbrio” não está apenas no modo como o léxico é selecionado, mas também no modo como a coluna é diagramada. A diagramação, como podemos 
observar, expõe os textos não de forma caótica, mas distribuídos simetricamente. Há um princípio de ordem também na diagramação, permitindo à leitora realizar uma leitura "harmônica” dos textos, de cima par baixo e da direita para a esquerda. Nesse sentido, podemos dizer que a leitora não é somente interessante e esclarecida no modo de se vestir, de dirigir um lar, de ser mãe, de ser esposa, mas ela é interessante e esclarecida no modo como conduz a sua leitura.

Vimos, também, em dirigir um lar, que o enunciador utiliza a metáfora da mulher economista, da "equilibrista" das finanças, para evocar o modo como a boa dona de casa deve dirigir sua casa, sendo econômica, sabendo o que deve ser comprado e o que deve ser evitado, nem gastando de menos, nem gastando de mais:

A economia é outro problema que a mulher tem de resolver com sabedoria: nem gastar de mais, nem de menos. Sacrifique um bibelô, não troque já as cortinas da sala, mas não deixe de faltar bons e fartos cardápios na sua mesa. Não sirva uísque às visitas, mas dê bastante frutas boas, escolhidas, não as já meio passadas e às vezes passadas demais, que diversas donas de casa costumam comprar por alguns tostões a menos.

Não entregue a direção das compras e das despesas inteiramente às empregadas, pois essa não é a função delas e quem tem de zelar pelo dinheiro de seu marido é você.

O texto a seguir valida essa cenografia de uma "economista” que sabe intervir no lar. É só lermos o título para depreendermos tal evocação: para renovar o seu guardachuva. A força do argumento de que a mulher deve ser uma "equilibrista" das finanças está no verbo renovar. A mulher encenada sabe sacrificar os gastos com um novo guarda-chuva, e renovando o seu guarda-chuva, ela equilibra as finanças da casa, podendo comprar abacaxi para fazer compota de abacaxi (receita culinária editada na mesma coluna).

Continuando a leitura da coluna, os textos que seguem para renovar o seu guarda-chuva tratam do tema da beleza: se você emagreceu de repente...; toda pele precisa de nutrição; gordura... esse fantasma!. O princípio do "equilíbrio"/da “harmonização” também valida o corpo dessa mulher interessante e esclarecida, ou seja, ela deve procurar o "equilíbrio” do corpo, não podendo nem emagrecer de repente, nem engordar. A dieta da mulher interessante e esclarecida deve ser realizada de modo racional. Dessa forma, ela evita a flacidez e o envelhecimento da pele. 
Para manter uma beleza "harmônica" do rosto, a mulher interessante e esclarecida deve saber qual o creme ideal para "equilibrar” a umidade e o ressecamento da pele. Nesse momento (toda pele precisa de nutrição), o enunciador faz aparecer nas entrelinhas “o plano publicitário dos produtos Pond's”. Segundo as normas do plano, a publicidade dos produtos deve ser de modo indireto, sem indicar o nome, mas suas propriedades recomendáveis e a necessidade de seu uso (ver enunciado sublinhado no texto):

Toda pele precisa de nutrição
E para isso existem os cremes. Se você deixa a sua pele sem cuidados, ela vai perdendo
a umidade, ressecando, envelhecendo. Para casos assim, existem agora uns cremes
$\underline{\text { especiais, acrescidos de uma nova substância - alantoina - que é, segundo os técnicos, }}$
$\underline{\text { uma raiz medicinal de surpreendentes virtudes rejuvenescedoras. Esses produtos }}$
$\underline{\text { restauram o teor de umidade necessário à pele, destruindo as camadas ressequidas. Se a }}$
$\underline{\text { sua pele tem tendência a pele seca, aconselho-a a experimentar um desses cremes, a }}$
$\underline{\text { fim de preservar a juventude de seu rosto, pois nada envelhece mais do que uma pele }}$
$\underline{\text { riscada pelas rugas, pelos pés-de-galinha e pelos sulcos. }}$

Para validar essa cenografia de uma mulher interessante e esclarecida que sabe intervir no seu campo de ação (no casamento, no lar, na família), o enunciador insere outras vozes em forma de discurso direto, ou seja, o discurso outro é inserido na coluna de modo aspeado:

1. “As rugas da velhice deveriam ser apenas os vestígios dos sorrisos da juventude";

2. "Seja generosa, leal, bondosa e firme em seus gestos e atitudes. Esses sentimentos transparecerão em seu rosto e atrairão a simpatia de todos que a cercam” Terry Hunt.

O enunciado 1 (L1) e o enunciado 2 (L2) relatam um outro ato de enunciação, não é mais o locutor de Feira de utilidades (Lo) que o diz, mas um outro locutor: em 1, um locutor outro que não é assumido por um falante concreto, é uma voz indeterminada, 
genérica; em 2, um locutor outro assumido por Terry Hunt. Ou seja, o locutor da coluna faz menção à palavra alheia, usando as próprias palavras do discurso outro. Assim, temos o seguinte esquema:

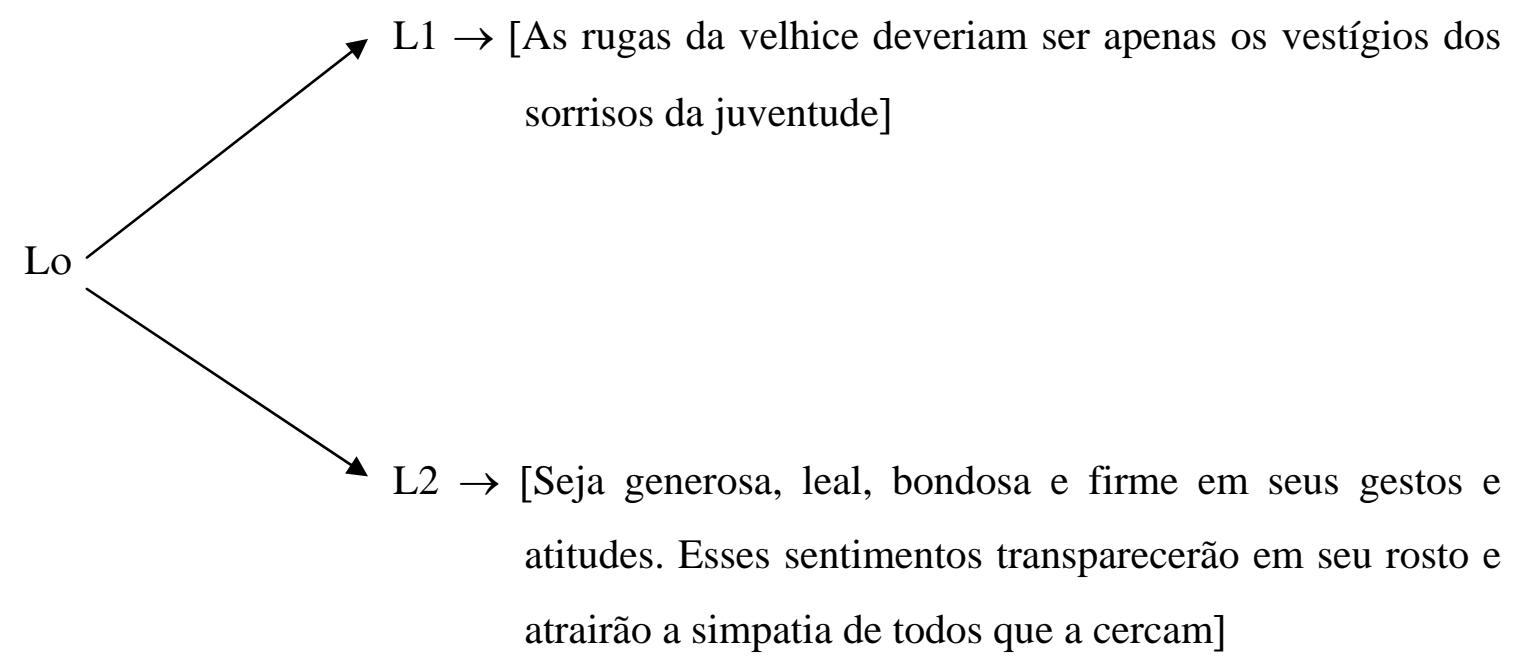

Concluímos então que os locutores dos enunciados acima não coincidem, mas quanto ao seu posicionamento, a voz de L1 é consonante com o posicionamento da voz de Lo. Assim como o posicionamento de L2 é consonante com o posicionamento de Lo. Frente a esse quadro, podemos dizer que o discurso outro em forma de discurso relatado aparece para validar o posicionamento do enunciador da coluna. Na realidade, esse discurso outro é apresentado como argumento de autoridade para mostrar que o saber da mulher interessante e esclarecida é construído por várias outras vozes provenientes de outros saberes.

É apresentado, também, nesse espaço, um quadrinho cuja personagem Amélia relata seus problemas. Nessa edição, o problema de Amélia é: Já servi damasco gelado e quente, não sei o que fazer mais para variar. Como uma dona de casa que sabe bem dirigir um lar, Amélia se preocupa com o cardápio que pretende servir à sua família. Amélia não pode cair no “exagero” ou “desleixo” de sempre servir o mesmo prato.

Com um tom de amiga conselheira, a enunciadora da coluna responde: é fácil, Amélia, ponha o damasco num copo de sorvete e encha-o com tapioca para a sobremesa, ou então, recheie-o com queijo creme misturado com clocleária. Será uma maravilhosa guarnição para um prato de carne. 
Depreende-se desse quadrinho a voz da leitora dessa coluna, que é a voz de Amélia. Há um efeito de identificação entre a leitora dona de casa e a personagem Amélia também dona de casa. Com relação à personagem Amélia, podemos estabelecer uma intertextualidade com a Amélia da canção de Ataulfo Alves e Mario Lago, ai que saudade da Amélia. Nessa canção, a saudosa Amélia é a mulher de verdade, sem exigências, a mulher do lar que não tem nenhuma vaidade e às vezes passa fome ao lado do seu companheiro. A Amélia da canção é o estereótipo da dona de casa perfeita sem vaidade, enquanto o enunciador de Feira de utilidades constrói o simulacro de uma outra Amélia, uma dona de casa esclarecida, preocupada com as dificuldades da vida atual e que tenta resolver seus problemas domésticos com sabedoria.

A dona de casa de Feira de utilidades, como sugere o primeiro número da coluna, deve ser esclarecida, acompanhando o ritmo da vida atual, sendo útil dentro do seu campo de ação, fazendo-se respeitar pelo seu valor próprio, que é companheira do homem e não sua escrava. Para acompanhar o ritmo de vida atual, a mulher esclarecida estuda, lê, é moderna e interessante sem perder seus atributos de mulher, esposa e mãe. A mulher esclarecida deve conhecer alguma coisa além do seu tricô, dos seus quitutes e dos seus bate-papos com as vizinhas. A fala abaixo da personagem Amélia legitima a enunciação de uma dona de casa preocupada com o tempo, pois o seu modo de vida atual exige dela receitas mais práticas:

- Minha refeição ligeira é feita só de milho e pimenta, e fica uma delícia! (Correio da Manhã, 27 janeiro de1960).

Por fim, o texto pudor nos pés! :

Existem certos lugares na Ásia Central onde se uma mulher passar deixando ver os pés, as senhoras honestas coram e viram o rosto como se estivessem vendo a última das inconveniências. Na China, até algum tempo atrás, falar em pés femininos era obscenidade e nenhum pintor mostrava os pés das figuras femininas de seus modelos. Na Espanha, no fim do século XVII, as roupas eram longas, arrastavam-se pelo chão, escorrendo os pés. E quando a rainha Luiza de Sabóia, mulher de Felipe V, mandou as mulheres encurtarem as saias alguns centímetros a fim de não levantar tanta poeira quando passavam, muitos maridos declararam que preferiam suas esposas mortas que expostas a tal "despudor". Como mudam os tempos! 
Esse texto, ao contrário de todos os outros, tem um caráter mais informativo. Esse seu caráter informativo está em consonância com a imagem da mulher interessante e esclarecida que o enunciador procura validar através da cena enunciativa. Ou seja, a mulher interessante e esclarecida não limita seus interesses apenas às tarefas domésticas e aos cuidados com a beleza. Ela procura ler, se informar e estar a par dos acontecimentos do mundo. Nesse texto, ao invés do enunciador aconselhar com dicas de beleza, o enunciador informa sua leitora de um fato cultural e histórico.

O poder argumentativo desse texto está justamente no enunciado como mudam os tempos!. Com esse enunciado, o texto valida a discursividade de que a mulher deve estar a par das dificuldades da vida atual. Como mudam os tempos! sugere à mulher que não fique apegada a valores passados, pois os tempos são outros. Por isso, Amélia não pode mais ser a Amélia que era mulher de verdade. A Amélia da coluna deve acompanhar o ritmo de vida atual. 


\title{
(3)
}

\section{Feira de utilidades: a mulher esclarecida em "cena”}

\author{
"É preciso estar pronto para \\ acolher cada momento no discurso \\ em sua irrupção de acontecimento \\ (...) é preciso tratá-lo no jogo de sua instância”
}

Michel Foucault, A arqueologia do saber.

\subsection{Considerações iniciais}

No capítulo anterior, mostramos como o gênero coluna feminina, enquanto prática discursiva, é um ritual convencionado socialmente e submetido a um critério de êxito que envolve elementos de ordem textual e não textual: uma finalidade reconhecida; o estatuto de parceiros legítimos; o lugar e o momento legítimos; um suporte material; uma organização textual.

Segundo Maingueneau, a noção de prática discursiva faz aparecer uma imbricação entre ambiente enunciativo imediato e ambiente institucional através de um sistema de restrições semânticas comuns. É nessa imbricação que os gêneros são produzidos e se fazem circular. Para observar essa imbricação que constitui Feira de utilidades, elegemos o estatuto de parceiros legítimos como desfecho da nossa análise, pois cada gênero define "o estatuto que o enunciador deve conferir-se e o que conferir a seu destinatário para legitimar o seu dizer”.

Considerando que Feira de utilidades funciona como prática discursiva, é insuficiente ver a instância subjetiva somente associada a um estatuto de parceiros legítimos. Faz-se necessário observar como se dá a adesão dos sujeitos a uma posição discursiva, marcada por características amplamente históricas.

Para refletir sobre essa imbricação entre o modo de enunciação e o lugar histórico de onde emerge essa enunciação, recorremos à noção de ethos postulada por Maingueneau (2005: 70) que entende a instância subjetiva como 'voz' e 'corpo 
enunciante', historicamente especificado e inscrito em uma situação, que sua enunciação ao mesmo tempo pressupõe e valida progressivamente.

Os pressupostos acima nos levam a pensar a noção de ethos como questão central desse capítulo, uma vez que o "simples fato de que um texto pertencer a um gênero de discurso ou a um certo posicionamento ideológico induz expectativas em matéria de ethos” (MAINGUENEAU, 2005: 71). Entendendo ethos como uma maneira de dizer que remete a uma maneira de ser, tentamos mostrar como a Feira de utilidades no processo de sua constituição legitima a discursividade da mulher esclarecida.

Ao produzir um espaço onde se desdobra uma “voz” da mulher além do lar, da mulher esclarecida, o enunciador cria tensões com a "voz" da mulher do lar presente em outros textos veiculados pela coluna. Nesse jogo entre o outro e o mesmo, o enunciador da coluna aponta a constituição de uma posição sujeito que indica uma moral em que as mulheres não sejam escravas do lar, do seu companheiro, da arte de embelezar-se; em que a mulher saiba que ela não está mais no tempo em que sua única finalidade seria arranjar marido; em que a mulher deixa de ocupar um espaço submisso. Uma moral que sofre influência das mudanças de comportamento decorrente do aumento das possibilidades educacionais e profissionais para as mulheres, conforme aponta Bassanezi (2002).

Vejamos, então, o modo como a coluna materializa em suas formulações esse discurso em que se desdobra a "voz” da mulher esclarecida. Ou melhor, o modo como a "voz" da mulher esclarecida evoca, acolhe, absorve e reconfigura os temas da “verdadeira” essência feminina: casamento, maternidade, cuidados com o lar, beleza, moda. 


\title{
3.2 A mulher esclarecida em “cena”: o vínculo conjugal
}

\author{
“Os entendidos no assunto costumam dizer que os casamentos mais felizes são \\ aqueles que imperam um sentimento de camaradagem, compatibilidade amorosa e \\ mútua determinação de fazer com que o mesmo tenha êxito” (Correio da Manhã, 22 \\ de abril de 1960);
}

Na ideologia dos anos 50, o destino que a sociedade propõe tradicionalmente à mulher é o vínculo conjugal que, segundo Foucault (2002c: 152), define "uma relação dual em sua forma, universal em seu valor e específica em sua intensidade e força”.

Com relação à forma, o autor mostra como a constituição binária da espécie humana é um dos princípios que impulsionam a união entre o homem e a mulher. Em suma, “o homem é, de todo modo, um ser conjugal”. Já o seu valor se constrói na relação entre a obrigação de casar-se e a conjuntura.

Enquanto a relação universal se refere ao casamento como uma obrigação social ao lado dos deveres que concernem à vida política, à religião e à família, a relação específica de um vínculo conjugal se caracteriza por uma complementaridade e repartição de encargos.

Pensando na relação específica, o casamento exige um estilo de conduta da mulher cuja felicidade está voltada para o lar. No dizer das "páginas femininas” da imprensa dos anos 50, as mulheres casadas deveriam ter, como centro de suas preocupações, o marido e os filhos, com a finalidade de sempre manter a harmonia do lar. Em suma, o estilo de vida imposto pelo casamento, na ideologia dos anos dourados, exige da mulher assumir seu papel de boa esposa, mãe e dona de casa. Essa relação específica do casamento pode ser observada no excerto abaixo retirado da revista $O$ Cruzeiro: 
Quando me casei não entendia nada de arranjos domésticos. Em solteira costumava dormir até tarde e qualquer trabalho de casa me causava verdadeira aversão. Depois, embora com grande disciplina da minha parte, consegui modificar meu gosto. Dizem que a dor ensina a gemer. Comigo não foi bem assim: foi a necessidade que me obrigou a gostar daquilo que antigamente me parecia sem graça. Hoje, segundo meu marido - e modéstia à parte - sou excelente dona de casa. Oxalá pudéssemos receber muitas cartas nesse teor! Quem dera que todas as moças, ao encetarem a nova vida, aproveitassem a oportunidade para adaptarem seus gostos e seus hábitos às exigências que lhes são impostas pelo novo estado” (20 de junho 1959).

Essa discursividade de adaptação às exigências impostas pelo casamento era comum, também, no dizer de Feira de utilidades. Assim como as demais revistas e suplementos da época, Feira de utilidades procurava mostrar o quanto as mulheres podiam influenciar sobre a vida do marido, se desempenhassem bem as tarefas domésticas. No dizer da coluna, a discursividade do casamento na "voz" da mulher do lar propõe o equilíbrio conjugal como responsabilidade da mulher que deve buscar manter sempre o lar organizado. Esse discurso que valida o equilíbrio conjugal associado à harmonia do lar é afirmado através das seguintes formulações:

- Somente uma mulher, e dona de casa, sabe e reconhece a grande tarefa que é bem dirigir uma casa. A dona de casa tem de ser antes de tudo, uma economista, uma "equilibrista" das finanças, principalmente com as dificuldades da vida atual. O lar é o lugar onde devemos encontrar a nossa paz de espírito num ambiente limpo, sadio e agradável e cabe à mulher providenciar isso (Correio da Manhã, 24 de fevereiro de 1960);

- As mulheres têm e deverão ter grande influência na vida do marido (...) Que deverá você fazer para ajudar seu marido a progredir na vida? Primeiramente, deve mostrar-lhe por diversos meios que tem confiança nele; ao mesmo tempo deve tomar interesse por seu trabalho, ouvir suas longas dissertações sobre os acontecimentos do dia, e procurar manter sempre a casa limpa... apresentar refeições gostosas e agradáveis à vista (Correio da Manhã, 20 de dezembro de 1960); 
Se, por um lado, podemos identificar uma posição sujeito ocupada por mulheres de classe média que estão associadas ao lar, por outro lado, podemos encontrar na coluna discursos referentes à não limitação da mulher ao casamento e, conseqüentemente, ao lar. Essa discursividade além lar legitima a mulher na qual a coluna investe, que é esclarecida/inteligente, moderna, interessante, sabe acompanhar o ritmo da vida atual e, por isso, instrui-se, lê, estuda, faz-se respeitar pelo seu próprio valor, não sendo submissa às vontades do marido. Para exemplificar essa discursividade, vejamos o texto que abre a primeira coluna publicada em 21 de agosto de $1959^{23}$ :

\begin{abstract}
Uma mulher esclarecida
Uma "mulher esclarecida” não é, como algumas querem fazer crer, e muitos homens sabidos teimam em convencê-las, sem escrúpulos e sem preconceitos, pois a viver como parte de uma sociedade, toda criatura tem de seguir as leis dessa sociedade, quer as achem certas ou não. Digo-lhes que "esclarecida" é a mulher que se instrui, que procura acompanhar o ritmo da vida atual, sendo útil dentro do seu campo de ação, fazendo-se respeitar pelo seu valor próprio, que é companheira do homem e não sua escrava, que é mãe e educadora e não boneca mimada a criar outros bonequinhos mimados.

O fato de uma mulher ser livre não implica em que ela deva se libertar dos liames de moral e pudor, que são, afinal, embelezadores da mulher e, portanto, indispensáveis à sua personalidade.

A mulher esclarecida sabe disso. Ela estuda, ela lê, ela é moderna e interessante sem perder seus atributos de mulher, esposa e mãe. Não tem necessariamente de trazer um diploma e um título, mas conhece alguma coisa mais além do seu tricô, dos seus quitutes e dos seus bate-papos com as vizinhas. Ela cultiva, especialmente, a sua capacidade de ser compreensiva e humana. Tem coração. Despoja-se do sentimentalismo barato e inútil, e aplica sabiamente a sua bondade e a sua ternura. É mulher.

Você, minha leitora, não limite o seu interesse à arte de embelezar-se, de ser elegante, de atrair os olhares masculinos. A futilidade é fraqueza superada pela mulher esclarecida. E você é uma “mulher esclarecida”, não é mesmo? (Correio da Manhã, 21 de agosto de 1959).
\end{abstract}

\footnotetext{
${ }^{23}$ Outros textos concorrem para a construção de significado dessa primeira coluna. São eles: Você sofre de varizes?; Você sabia?; Ninguém deve parecer mais velha do que é...; Uma receita barata para você souflê de cenoura; Sobre o amor; Não desperdice a sua vida alimentando rancores inúteis; Máscara de beleza; Pequenos conselhos para a dona de casa; O precioso limão; Para os que estão enfraquecidos; Conselheira espirituosa; além do quadrinho protagonizado pela personagem Amélia. Com exceção de Uma mulher esclarecida, Você sabia? e Sobre o amor, a coluna é constituída por uma quantidade significativa de dicas e receitas que se dedicam ao cuidado de si e utilidades domésticas. Em termos percentuais, as dicas e receitas correspondem a 77\% dos textos. Esses textos, conforme vimos no capítulo 3 , validam a finalidade da coluna que é a de aconselhar a mulher com dicas domésticas para que esta possa ser uma dona de casa prendada, cuidando bem dos filhos e marido, e dicas de beleza para que seja bela sem parecer mais velha do que é.
} 
Nas formulações desse texto, podemos identificar o público leitor dessa coluna. Ou melhor, os indícios textuais nos permitem definir o estatuto "mulher esclarecida" que o enunciador confere a si e ao seu co-enunciador; determina a comunidade imaginária dos que devem aderir a esse discurso. Essa comunidade imaginária é enunciada por um ethos de mulher esclarecida que se apóia sobre um conjunto de representações sociais valorizadas (Ela estuda, ela lê, ela é moderna e interessante sem perder seus atributos de mulher, esposa e mãe) que validam o atributo esclarecida. A mulher que deve ser esclarecida é representada por um fiador que encarna o "plano do saber" (a mulher que se instrui; A mulher esclarecida sabe disso; Ela estuda, ela lêe, ela é moderna; aplica sabiamente a sua bondade e a sua ternura). E mesmo ao encarnar esse "plano do saber", o fiador sabe cultivar os embelezadores da mulher.

Essa fiadora, que é esclarecida e sabe cultivar os embelezadores da mulher, é validada pela enunciação sábia e equilibrada que o texto exibe: verbos que compõem o grupo do saber (instruir, saber, estudar ler); atributivos que legitimam a corporalidade da fiadora (moderna, interessante, educadora, compreensiva, bondosa); operadores argumentativos que legitimam o caráter equilibrado ( $O$ fato de uma mulher ser livre não implica em que ela deva se libertar dos liames de moral e pudor; Não tem necessariamente de trazer um diploma e um título, mas conhece alguma coisa mais além do seu tricô, dos seus quitutes e dos seus bate-papos com as vizinhas). Todos esses elementos apontados legitimam o modo como a fiadora se movimenta no espaço social, desqualificando a mulher que se move na sociedade de modo "escravo", apegada ao sentimentalismo barato, limitada às tarefas domésticas e à arte de embelezar-se.

A topografia da cena de enunciação, depreendida a partir da referência atual (procura acompanhar o ritmo da vida atual), também valida o caráter esclarecido dessa mulher que sabe e reconhece sua obrigação em seguir as leis da sociedade em que vive (toda criatura tem de seguir as leis dessa sociedade). Dizer que a mulher procura acompanhar o ritmo da vida atual implica em dizer que essa mulher na qual a coluna investe é atualizada. Nesse sentido, ser atualizada valida o caráter esclarecido dessa mulher.

Para assumir essa posição discursiva que indica uma moral em que a mulher não deve se limitar às tarefas domésticas e à arte de embelezar-se, o Sujeito precisa da relação com Outro. Nesse jogo entre o Outro e o mesmo, a mulher escrava/limitada (antifiador) é investida de forma negativa. O corpo do “antifiador” é deslegitimado por 
uma rede metafórica centrada no saber. Esse ataque à mulher escrava, à mulher que se limita ao âmbito do lar e à arte de embelezar-se é importante para que a mulher esclarecida possa constituir e preservar a sua identidade, pois, segundo Maingueneau (2005), “cada discurso deve simultaneamente responder aos golpes que recebe e dar golpes”.

Os enunciados produzidos pelo discurso da mulher esclarecida pouco a pouco tecem uma memória própria do discurso, uma memória interna que vai se enriquecendo e que perpassa por todos os temas englobados. Mas para legitimar essa memória interna, o discurso cria filiações, laços externos. No caso do discurso da mulher esclarecida, esses laços são promovidos pela palavra mulher (como já falamos anteriormente resgata os papéis de esposa, mãe e dona de casa), enquanto a “renovação” está no atributivo esclarecida que engendra a memória interna dessa discursividade.

Para a mulher esclarecida, a prática do casamento não impera. Não é simplesmente em relação ao casamento que se define a figura da mulher. O contato com o saber modifica a condição feminina, principalmente, a instituição do casamento. A mulher não se acha mais confinada a arranjar marido e, conseqüentemente, a mulher não está confinada ao lar. No texto abaixo, a mulher assume uma postura mais definida em relação à inserção da mulher nas universidades e, conseqüentemente, ao casamento:

\footnotetext{
Arranjar marido...

Nós não estamos mais no tempo em que a única finalidade de uma jovem era arranjar marido. Não importava de que qualidade fosse. Um marido, era o objetivo. Felizmente, isso passou. Hoje, freqüentando universidade, libertando-se dos falsos tabus que faziam da mulher um ser inferior e eternamente submisso, o problema do casamento passou a ser encarado de forma muito mais (acertada) e serena. Se uma jovem não encontra seu ideal não casa, pronto. Nada de mal lhe advém daí. A sociedade esqueceu o antigo preconceito contra as solteironas, e mulher passou a ser respeitada pelo seu valor próprio, sem precisar de uma presença masculina ao seu lado para se impor. Existem ainda umas mocinhas antiquadas que vivem esse drama ridículo do "caçar" marido. A essas, gostaria de aconselhar a acompanharem a época. Que queiram casar-se, ter seus lares e seus filhos, é natural. Naturalíssimo. Mas escolham seu marido como companheiro da sua vida, o homem que hão de amar e respeitar até o fim de seus dias. Nada de precipitação. Se o homem ideal não aparece hoje, aparecerá amanhã. Um erro na escolha de seu marido pode ser a causa de todo um futuro estragado. Não apenas do seu futuro. Mas também o de seus filhos. (Correio da Manhã, 30 de outubro de 1959).
} 
As formulações de arranjar marido indicam um corpo feminino condizente com ethos de Feira de utilidades, que, desde a sua primeira edição (como vimos acima), dedica espaço à mulher esclarecida, à mulher que sabe aproveitar seu tempo com uma boa leitura, elementos fundamentais que definem o modo como a mulher deve habitar o espaço social.

Assim como em uma mulher esclarecida, podemos observar um enunciador que não rompe com a tradição do casamento. Para o enunciador, o casamento continua sendo algo natural (Que queiram casar-se, ter seus lares e seus filhos, é natural); é aceitável que ela exerça seu papel de esposa, dona de casa e mãe. O que continua sendo inaceitável é o fato da mulher se limitar apenas a esses papéis (Existem ainda umas mocinhas antiquadas que vivem esse drama ridículo do "caçar" marido. A essas, gostaria de aconselhar a acompanharem a época). A leitora de Feira de utilidades é, então, levada/aconselhada a incorporar o saber (freqüentando universidade, lendo, estudando).

Isso mostra, também, como Feira de utilidades está atualizada com as transformações do seu tempo e mostra à sua leitora o aumento das possibilidades educacionais e profissionais para as mulheres. Segundo Bassanezi (2002: 624), todo esse processo de melhores possibilidades educacionais e profissionais ajuda a diminuir a distância entre homens e mulheres.

Segundo a historiadora, há uma estreita relação entre o aumento das possibilidades educacionais e das profissionais, pois, uma vez que o mercado de trabalho na década de cinqüenta exige uma maior participação feminina especialmente no setor de serviços de consumo coletivo, em escritórios, no comércio ou em serviços públicos, conseqüentemente, há uma maior demanda da escolaridade feminina provocando, sem dúvida, mudanças no status social das mulheres. Feira de utilidades, por ser a coluna da mulher esclarecida que está a par do seu tempo, dos acontecimentos que estão ao seu redor, não deixa de tratar desse assunto, como podemos observar no excerto abaixo:

As mulheres gostam de trabalhar fora? - Há dois grupos de mulheres que trabalham fora, as solteiras e as casadas. As solteiras trabalham por várias razões, cada uma variando de acordo com os problemas e conveniências de sua vida. A casada, de um modo em geral, trabalha para promover o sustento do lar ou ajudar na manutenção 
do mesmo. É, portanto, um trabalho por necessidade, seja ela pequena ou grande. (Correio da Manhã, 3 de agosto de 1960).

Com relação à incorporação do saber, podemos observá-la em outros títulos de texto da coluna como em: aproveitemos o tempo com inteligência. Esse título merece destaque, uma vez que retrata o modo como a leitora deve se portar. Ou seja, a leitora da coluna não é aconselhada simplesmente a aproveitar o tempo, mas a saber aproveitá-lo com inteligência. Esse texto encarna as propriedades que condizem com ethos da mulher esclarecida e desqualifica a mulher cuja finalidade é recorrer às conversar com as vizinhas, às novelas radiofônicas. Das formulações do texto, destacamos a seguinte:

- Por que não empregar esse tempo em algo realmente agradável e proveitoso? Em ler um bom livro, por exemplo (Correio da Manhã, 25 de setembro de 1960).

Na construção da identidade dessa mulher esclarecida, a coluna publica, desde o início, pelo menos um excerto aspeado, cujo enunciador está freqüentemente associado ao discurso literário/filosófico. Esses excertos literários/filosóficos indicam que a mulher na qual a coluna investe é boa leitora, pois sabe aproveitar seu tempo lendo um bom livro. Vejamos alguns desses excertos:

- Em amor há dois tempos, aquele em que ele nos arrasta como uma tempestade, e aqueles em que arrastamos como uma cadeia” Vargas Vila (?) (Correio da Manhã, 21 de agosto de 1959);

- “É tão fugaz essa graça, que aos homens Deus ofertou, que só depois que ela passa, se sabe que ela passou” Felicidade - Ferreira Gullar (Correio da Manhã, 28 de agosto de 1959);

- "São as boas qualidades e não a beleza de uma mulher que fazem os casamentos felizes. A mulher que nos ama sabe fazer-se bela” Honoré Balzac (Correio da Manhã, 4 de setembro 1959);

- "Veja o rio, lindas flores/Veja as praias, veja o mar/ Mas pra que ver tanta coisa/ Se não vejo o teu olhar” A poesia pra você - Luiz Otávio (Correio da Manhã, 4 de outubro de 1959); 
- "Logo nos enfada uma mulher bonita, jamais nos cansa a mulher bondosa" Montaigne (Correio da Manhã, 4 de novembro de 1959);

- "Quem por lança e por escudo. Tem beleza que mais quer? Vencem o ferro, o fogo e tudo os amantes da mulher" Anacreonte (Correio da Manhã, 13 de novembro de 1959);

- "O melhor aspecto da beleza é aquele que um retrato não pode exprimir" Francis Bacon (Correio da Manhã, 25 de dezembro de 1959);

- “Tudo tem sua beleza, mas nem todo mundo a vê" Confúcio (Correio da Manhã, 06 de fevereiro de 1960);

- "Eu te esperava, eu te sigo... Vamos... arrasta-me... assim... Mas deixa o meu cão na terra pra eu ter quem chore por mim!” Les nuits d'hiver de Henri Murger - tradução de Castro Alves (Correio da Manhã, 17 de fevereiro de 1960);

- “Para quem é pouca coisa, basta-lhe pouca coisa” Horácio (Correio da Manhã, 27 de abril de 1960);

- “A pátria está no lugar a que a alma está presa” Voltaire (Correio da Manhã, 27 de abril de 1960);

A rede de formulações acima, além de validar o caráter esclarecido do fiador, reafirma o discurso que a mulher deve possuir boas qualidades, entre elas a bondade, para manter a felicidade no casamento (São as boas qualidades e não a beleza de uma mulher que fazem os casamentos felizes; Logo nos enfada uma mulher bonita, jamais nos cansa a mulher bondosa); reafirma também a discursividade da beleza interior, discreta que evita recursos exagerados e extravagantes ( $O$ melhor aspecto da beleza é aquele que um retrato não pode exprimir; Tudo tem sua beleza, mas nem todo mundo a vê). 


\subsection{A mulher esclarecida em “cena”: a representação do corpo belo, jovem e saudável}

Vimos até o momento como a mulher esclarecida atua no e fora do lar; como essa mulher não está limitada às preocupações domésticas; como essa mulher procura o vínculo com o saber; como essa mulher, mesmo ocupando outros espaços como a universidade, não está livre dos seus deveres de mãe, esposa e dona de casa.

No capítulo anterior, ao tratarmos das coerções a que Feira de utilidades estava sujeita, vimos como a discursividade da beleza é constitutiva da imprensa feminina; como Feira de utilidades (sob coerção de um plano publicitário da Pond's) dedica espaço privilegiado a essa discursividade que nos anos 50 valida um corpo bem maquiado, bem vestido, sem excesso e extravagância. Assim, ao abordar essa discursividade, a coluna em comunhão com a sua cena englobante (imprensa feminina) procura sempre mostrar que o meio termo é ideal, isto é, a mulher deve sempre procurar evitar o exagero.

Mas o que está em jogo agora, não é simplesmente o que a coluna diz sobre os cuidados de si, mas o modo de enunciação dessa discursividade, ou seja, como o modo de enunciar da mulher esclarecida engendra essa discursividade. Vejamos, então, como a preocupação em ser bela, jovem e saudável não é desvinculada do estatuto esclarecida/inteligente que o enunciador confere a si e a seu destinatário:

\footnotetext{
A moda... e mulher inteligente

Ano a ano, variam as modas. Saias sobem, saias descem, saias armam, como abajures ou se estreitam como malha de bailarina. $E$ as mulheres obedecem à moda.

Decotes crescem ou minguam, cinturas se alargam ou se estreitam, penteados se complicam ou se desmancha, até a cor dos lábios, das unhas, das faces, dos cabelos se modifica. E as mulheres obedecem à moda.

Os saltos se afinam, engrossam, se curvam, deformam ou ajudam a figura. As fazendas brilham, tornam-se leves, com flores, com bordados, ou se puritanizam em cores escuras, em tecidos grossos. As mulheres obedecem sempre.

Todas as mulheres? Não. A mulher inteligente não é escrava dos caprichos dos costureiros, dos cabeleireiros ou dos fabricantes de cosméticos. Antes de adotar a última palavra da moda, ela estuda o efeito da mesma sobre o seu tipo. A mulher inteligente sabe que, mais importante que parecer “chique” é parecer bonita. Não quero dizer que
} 
ela ande fora de moda, use roupa e penteados antiquados. Mas o que ela usa é o que lhe fica bem, ajuda a sua figura, realça a cor e o brilho de seus olhos e cabelos, a cor de sua pele, remoça-a e torna-a ainda mais interessante para os olhos masculinos.

Espero que minhas leitoras pertençam a esse tipo de mulher. Gostaria que todas essas "escravas da moda”, que andam por aí, muitas vezes despertando o riso, pensassem um pouco antes de obedecer cegamente às ordens, nem sempre equilibradas, dos costureiros famosos, cujo interesse de despertar a atenção pela extravagância e pelo exagero parece crescer dia a dia. Bem triste idéia (dão) da mentalidade feminina essas pobres ingênuas. Andem na moda, claro! Adotem penteados, pintura, adereços modernos! Mas modernizem, antes de qualquer coisa, a sua mentalidade! Raciocinem, estudem a si próprias, em detalhes, lembrem-se de que o que fica bem a uma Elizabeth Taylor, miúda, frágil, com beleza de boneca, ficaria ridículo em Sophia Loren e vice-versa. No entanto, ambas são lindíssimas.

Observem como se vestem as mulheres tidas como as mais elegantes do mundo. A duquesa de Widsor, por exemplo. Nunca se entrega aos exageros da última moda, vestese discretamente, e é a rainha da elegância. Sem ter sido jamais uma mulher bonita, conseguiu conquistar um rei. Por ser uma mulher inteligente, sabe valorizar e tirar partido dos poucos encantos que possuem” (Correio da Manhã, 11 de dezembro de1959).

Nas formulações desse texto, assim como nas formulações de uma mulher esclarecida e arranjar marido, podemos observar marcado no próprio enunciado (Espero que minhas leitoras pertençam a esse tipo de mulher) um processo de comunicação entre mulheres inteligentes, esclarecidas, modernas. Nesse caso, a mulher esclarecida é a que não se submete aos caprichos da moda.

Mas o fato de não estar submetida aos caprichos da moda não quer dizer que a mulher esclarecida não se preocupe com o seu modo de vestir, de maquiar, como sugere o próprio enunciador da coluna (Não quero dizer que ela ande fora de moda, use roupa e penteados antiquados). E como já falamos anteriormente, a palavra mulher, além de resgatar no interior dessa prática discursiva os papéis de mãe, esposa e dona de casa, resgata também o caráter de feminilidade que é realçado, sobretudo, pelo cuidado de si. Ou melhor, na moral da imprensa feminina nos anos 50, a mulher é chamada a se firmar pelo seu caráter feminino.

Em Feira de utilidades, essa prática não é diferente. O que difere a coluna das demais "páginas femininas", ou seja, a "renovação" da coluna está no modo como a mulher é chamada a se firmar pelo seu caráter feminino. Numa década de tantas 
transformações em que aumenta a participação feminina nas atividades educacionais e profissionais, a coluna não podia ficar indiferente a esses acontecimentos, por isso (creio) a mulher é chamada a se firmar pelo seu caráter feminino não de modo escravo/submisso, mas esclarecido.

O texto acima, por sua própria enunciação, encarna propriedades associadas à mulher que tem domínio do "saber", uma mulher que hesita em adotar a última palavra da moda, sem antes estudar o efeito da mesma sobre o seu tipo. Para mostrar esse domínio do "saber", o enunciador não poupa o uso de verbos e atributivos cujo valor semântico está associado ao intelecto (ela estuda o efeito da mesma sobre o seu tipo; A mulher inteligente sabe que, mais importante que parecer “chique” é parecer bonita;

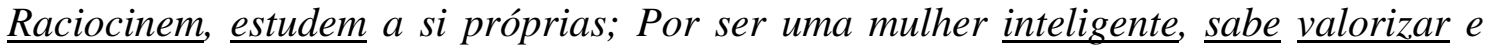
tirar partido dos poucos encantos que possuem).

A palavra vem de um enunciador que demonstra possuir senso crítico com relação à moda, provocando uma adesão da leitora que possui esse caráter. O tom crítico pode ser observado logo no início do texto, pois o enunciador se mostra preocupado não com a variação da moda, mas com as mulheres que obedecem à moda. Assim, o tom crítico é incorporado à fala do enunciador, legitimando o seu caráter “inteligente/esclarecido”.

Compreendemos, até o momento, a dimensão vocal (tom) e as determinações psíquicas (caráter) associadas à imagem do fiador. Vejamos, então, a partir dos indícios textuais, qual é a compleição corporal desse fiador que corresponde a uma maneira de se vestir e de se movimentar no espaço social.

Nas formulações de A moda... e a mulher inteligente, pode ser apreendido um fiador cuja corporalidade projeta a imagem de uma mulher bonita, elegante, vestida discretamente e, conseqüentemente, interessante aos olhos masculinos. Além da materialidade lingüística, essa corporalidade pode ser validada pela materialidade pictórica da coluna que exibe, ora por desenhos, ora por fotos, modelos elegantes e bem vestidas. 


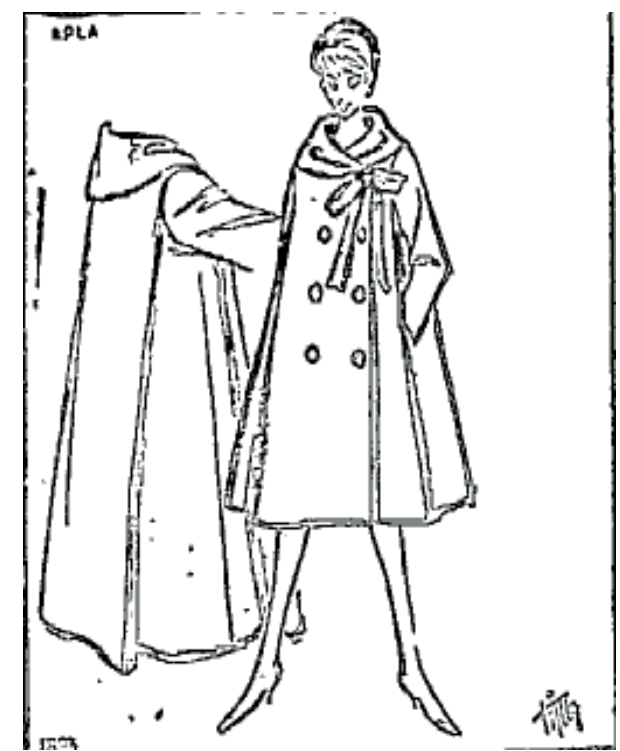

(Fig.1) ${ }^{24}$

(Abrigo elegante de grande efeito com dupla fileira de botões. Corte trapézio. Gola drapeada em forma de chale)

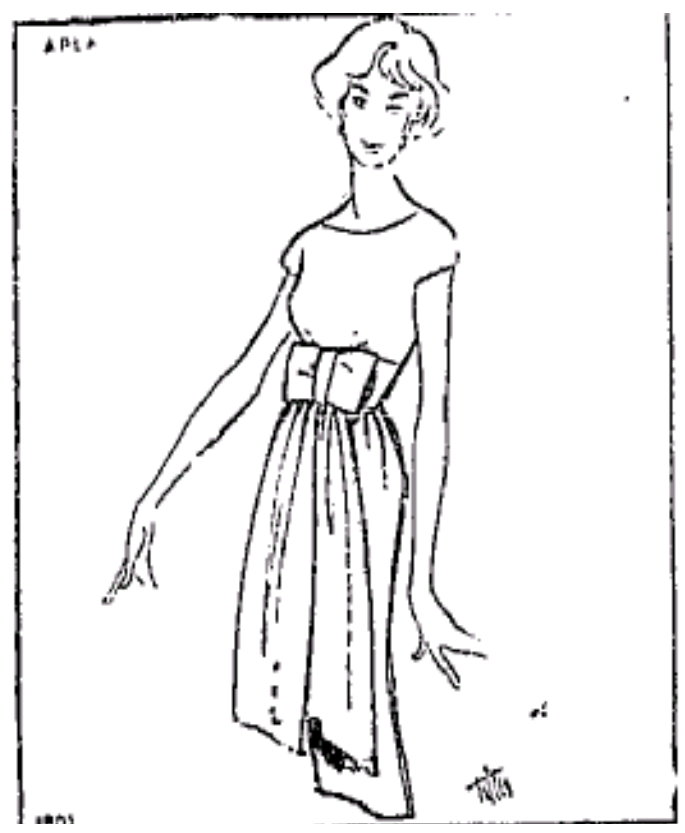

$(\text { Fig } 2)^{25}$

(Vestido juvenil, saia ligeiramente franzida na cintura e ampla faixa com laço que cai em forma de painel)

${ }^{24}$ Correio da Manhã, 18 de setembro de 1959

${ }^{25}$ Correio da Manhã, 2 de outubro de 1959. 


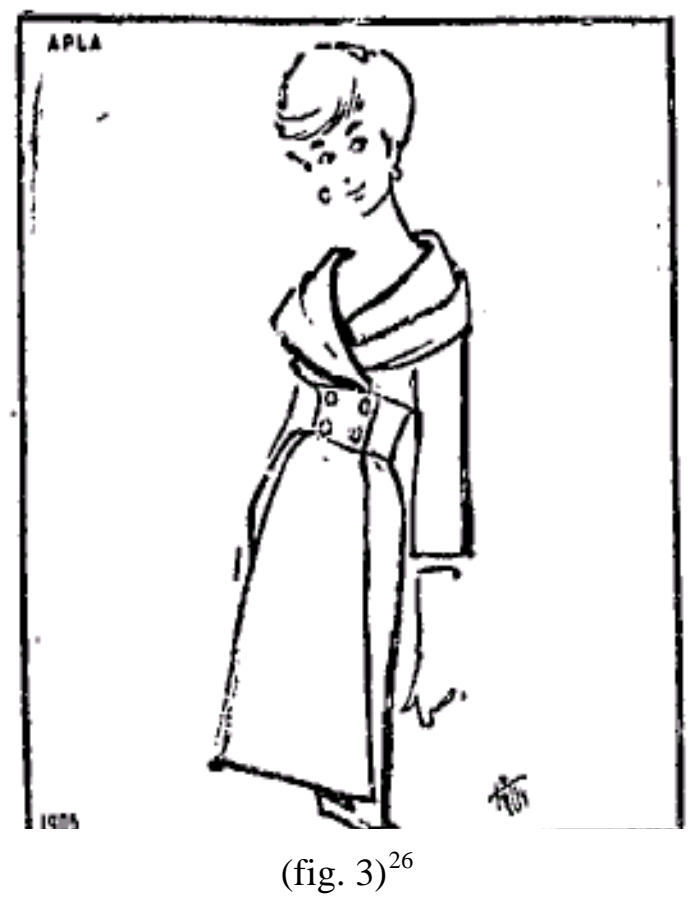

(Interessante modelo para tarde com saia justa e "painel” que simula cair do corpete. Mangas três-quartos e ampla faixa (cinto) com quatro botões)

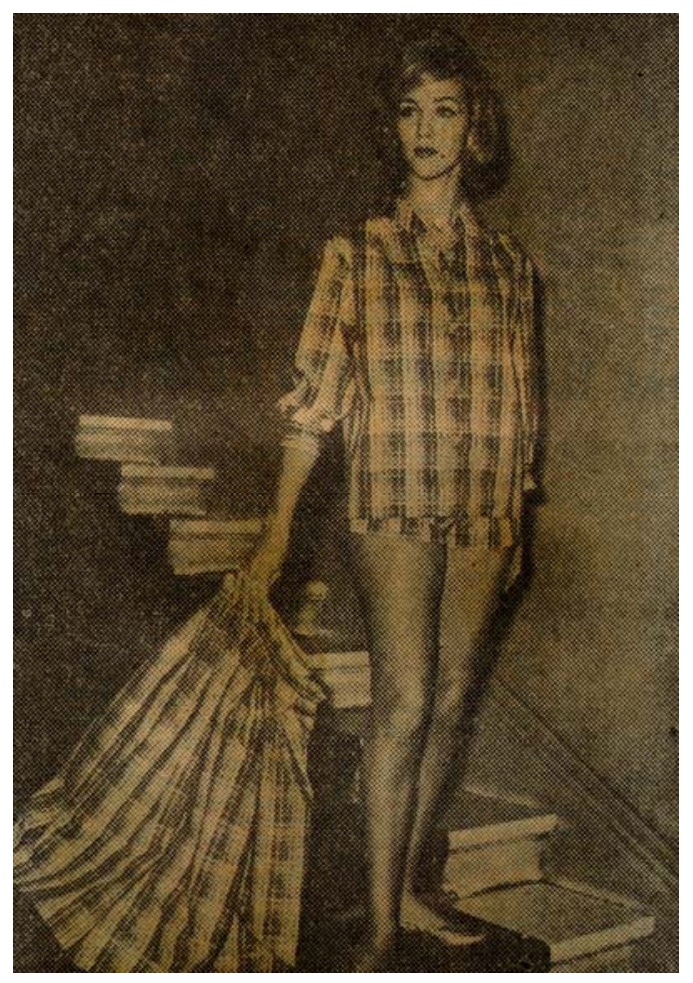

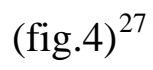

(Astre, conjunto de praia de três peças, "chamisier”, blusa e short de popeline listrada. Bela e sugestiva criação da União dos Costureiros da Costa Azul para Verão)

\footnotetext{
${ }^{26}$ Correio da Manhã, 25 de novembro de 1959

${ }^{27}$ Correio da Manhã, 15 de janeiro de 1960
} 


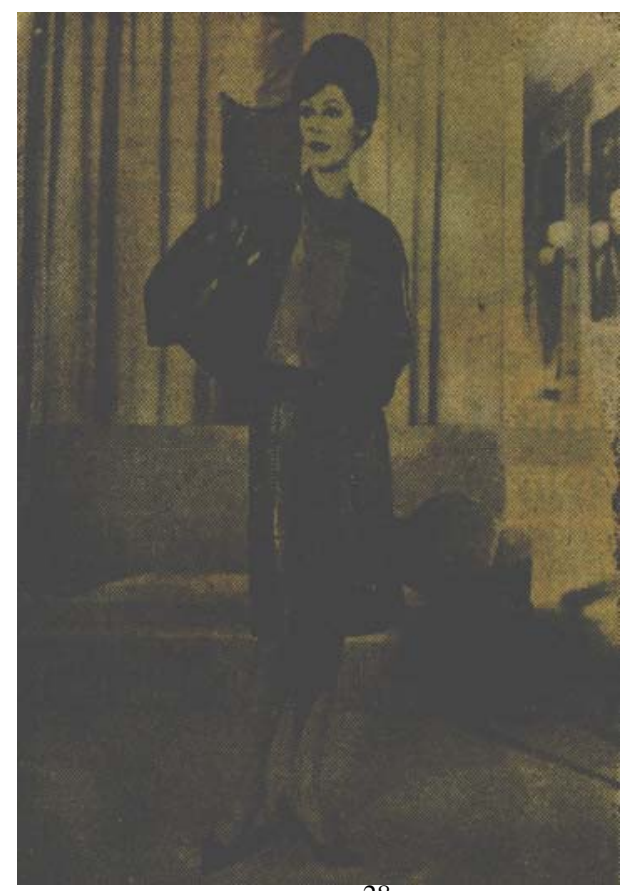

(fig. 5) $)^{28}$

(Cristian Dior criou para a próxima temporada esse vistoso "tailleur" em couro. "Chez Lipp” é o nome do gracioso modelo verde- bronzeado e blusa rosa vivo.)

Nas formulações lingüísticas das legendas, percebemos a materialização de um discurso no qual a roupa é extensão desse corpo, funcionando como artefato elegante, juvenil, interessante, belo e gracioso. Estando a roupa associada ao corpo, ela vai projetar na mulher uma imagem elegante, juvenil, interessante, bela e graciosa. Ou seja, esse é a maneira como a mulher esclarecida veste o seu corpo, de modo: elegante, juvenil, interessante, belo e gracioso.

Todos os indícios lingüísticos e pictóricos fazem uma representação da relação do fiador com a moda. Parafraseando Maingueneau (2005: 87), diríamos que o discurso visa estabelecer a co-presença desse ethos esclarecida e da moda. Dessa forma, a fiadora cujo corpo pode participar de tal cenografia é presumivelmente uma óbvia consumidora esclarecida da moda; reciprocamente, esse modo esclarecido de consumir a moda é destinado à mulher que pode entrar imaginariamente nessa cenografia, sendo elegante e inteligente como a duquesa de Windsor, que não se entrega aos exageros da última moda; que se veste discretamente; que estuda o seu tipo sabendo valorizar e tirar proveito dos seus encantos.

\footnotetext{
${ }^{28}$ Correio da Manhã, 12 de fevereiro de 1960.
} 
Na construção da identidade da feminilidade em Feira de utilidades, a compleição corporal da mulher esclarecida não se limita apenas a uma maneira de se vestir, pois, a discursividade sobre o corpo diz respeito, também, à beleza e à saúde. Desse modo, ao mesmo tempo em que se veste de modo inteligente, em harmonia com o seu tipo físico e personalidade, a mulher esclarecida maquia-se, embeleza-se, cuida da sua saúde, procurando validar seu caráter inteligente e esclarecido. Ou seja, a mulher em que Feira de utilidades investe deve procurar ser inteligente/esclarecida em todo o seu modo de cuidar do corpo. Esse posicionamento pode ser apreendido nas formulações do texto abaixo:

\begin{abstract}
A máscara da face
Os cosméticos são um bem ou um mal? - Na era como esta em que vivemos, em que tudo é feito à base de aparência e anúncio, com o domínio completo da publicidade, os cosméticos adquiriram muita importância para as mulheres e para o mundo em geral.

Cada ano aparece um novo tipo, que se consegue conjugando vários cosméticos, onde se incluem lápis de sobrancelha, rímel para os olhos, bastão para os lábios e os pancakes. Num ano, são os lábios que devem aparecer pintados, vermelho vivo, provocando a admiração de elementos masculinos. No outro ano, são os olhos que crescem de importância, eclipsando o resto do rosto, e deixando-o abatido e vago. As mulheres acompanham docilmente os ditames da moda, procurando fazer-se elas segundo os últimos figurinos.

Estará errado tudo isso? Não irá aí muito exagero, muito pretexto para ganho de dinheiro por parte dos negociantes e lançadores de moda? Não está sendo explorada a vaidade feminina e orgulho masculino para que os fins sejam conseguidos?

Acreditamos que o meio termo, como sempre, é a melhor atitude a tomar nesse assunto. Nem exageros de pintura, seguindo rigorosamente a moda, nem o desleixo, a falta absoluta de maquilage, deixando descoberto um rosto pálido, em contraste com os radiosos rostos das que se pintam. A mulher deve se conservar numa atitude de discrição, embora se pinte e procure ser bela, pois não há nada mais encantador que uma bela mulher vestida com roupas elegantes e modernas, mostrando o mais amável dos sorrisos! É mesmo um céu de vida! (Correio da Manhã, 5 de agosto de 1960).
\end{abstract}

Com o mesmo tom crítico de A moda... e a mulher esclarecida, o enunciador questiona os ditames da moda, a forma como a vaidade feminina é explorada pela publicidade que a cada ano lança um novo tipo de cosmético. A mulher na qual a coluna investe não pode se deixar “escravizar” pela indústria cosmética. Para isso, a mulher 
esclarecida deve procurar o meio termo no modo de se maquiar, como aconselha o enunciador: nem exageros de pinturas, nem o desleixo, a falta absoluta de maquilage.

O meio termo, a harmonia deve ser uma qualidade que a mulher esclarecida deve incorporar ao se vestir e ao se maquiar. O corpo da mulher esclarecida deve estar vestido e maquiado de modo a mantê-la elegante. Na discursividade do cuidado de si, além da roupa e da maquiagem, a mulher deve ter cuidado com a sua dieta (nem a magreza e nem a gordura em excesso), evitar a fadiga e uma vida sedentária, dormir bem, ou seja, a mulher deve procurar sempre recursos saudáveis para ser bonita em qualquer idade. Vejamos, então, como a prática da beleza mantém laços com a prática da saúde, isto é, como essas duas práticas constituem um elemento fundamental para a mulher esclarecida:

- Nunca devemos esquecer-nos de que a saúde é o ponto de partida para a beleza. A mulher doente apresenta fisionomia abatida, olheiras, marcas, olhos sem brilho. Portanto, além da obrigação que toda criatura humana tem de tratar de sua saúde, a mulher tem a obrigação extra de cuidar de seu organismo a fim de preservar a sua beleza (Correio da Manhã, 27 de janeiro 1959);

- Alimentando-se assim, você está não apenas armazenando saúde no seu organismo, mas também ajudando a sua elegância. Ser esbelta, bonita e saudável. Este deve ser o objetivo da mulher moderna e inteligente (Correio da Manhã, 27 de janeiro 1959);

- Procure fazer com que sua alimentação diária seja rica em vitaminas, especialmente vitaminas do complexo B. Com um tratamento simples assim, mas levado a sério, você poderá adquirir os quilinhos que lhe faltam, acabar com a expressão de cansaço, as olheiras, o desanimo, e ... ser mais bonita (Correio da Manhã, 27 de janeiro 1959);

- Uma batata do tamanho médio, esmagada com duas colheres de leite e uma colherinha de manteiga, fornece todos os elementos essenciais à saúde (Correio da Manhã, 20 de janeiro 1960);

- O sono é um grande amigo da mulher. Relaxa o corpo, nutre o organismo e traz suavidade às linhas do rosto (Correio da Manhã, 27 de janeiro 1960);

- As horas de sono devem ser reguladas, não apenas devido à saúde, mas também para conservar a beleza (...) Se a falta de sono compromete a saúde e a beleza, 
porém, o sono em excesso provoca o acúmulo de gorduras, e a obesidade é a nossa maior inimiga (Correio da Manhã, 8 de fevereiro 1960);

- O sol contém vitamina D, tão preciosa para a sua saúde, mas, em compensação, se você não se protege o seu rosto com um creme, esse mesmo sol queima e resseca a sua pele, escamando-a, manchando-a e, conseqüentemente, enfeiandoa (...) Acredite que estes conselhos são para proteger a sua saúde e a sua beleza (Correio da Manhã, 10 de fevereiro 1960);

- Felizmente, a mulher moderna já está aprendendo, aos poucos, a combinar elegância com saúde e no caso de seus olhos, já está compreendendo a importância que eles realmente têm (Correio da Manhã, 12 de fevereiro 1960);

- Beleza é quase sinônimo de alegria e saúde. A mulher inteligente procura sempre aparentar uma e outra - pelo menos aparentar - para manter o cetro de mulher atraente (Correio da Manhã, 2 de março 1960);

- As moças que desejam ter pele dourada, e procuram tostá-la rapidamente sob o sol inclemente estão fazendo a si próprias um grande mal e poderão, mesmo, não conseguir aquela tonalidade de aparência tão saudável e moderna (Correio da Manhã, 11 de março de 1960);

- O exercício ritmado faz grande bem à saúde e renova as energias, corrigindo as imperfeições do corpo e evitando um grande número de doenças (Correio da Manhã, 30 de março 1960);

- Coma bastante legumes e tome suco de frutas, para ter uma pele sadia (Correio da Manhã, 8 de abril de 1960);

- Os raios solares contêm vitamina D, você sabia? E a vitamina D fortalece os dentes, os ossos, faz bem ao sangue, embelezando, portanto, a pele. Não se esconda do sol. Ele é também amigo da beleza (Correio da Manhã, 2 de outubro 1960).

Nas formulações acima, vimos como os cuidados com a beleza do corpo estão intrinsecamente ligados aos cuidados com a saúde do corpo. Esse corpo com o qual a mulher moderna tem de se ocupar não é mais um corpo de uma jovem, mas de uma mulher de 40 anos; é um corpo mais fragilizado, constantemente, ameaçado pelo cansaço e pelo “acúmulo de gorduras”, por isso precisa de uma disciplina incessante (dieta saudável, exercícios ritmados, descanso contínuo) para se manter belo, jovem e saudável. 
Nesse quadro de intrínseca relação com a prática da saúde, os cuidados com o corpo se mostram numa correlação estreita com a prática médica que leva o enunciador da coluna a incorporar um saber médico. A divulgação dessa prática médica não circula no interior da comunidade médica; não visa à formação de especialistas. O destinatário dessa divulgação médica não é sua comunidade de origem (os médicos), mas uma leitora privada da competência médica que, ao ler a coluna, busca encontrar conselhos para deixar seu corpo belo, jovem e saudável.

Assim, para validar os conselhos mais “saudáveis”, por meio da enunciação do discurso de divulgação médica, o enunciador utiliza um léxico que remete ao campo médico, como podemos observar nas formulações abaixo:

- Existem diversos tipos de fadiga, sendo a mais comum a causada pela deficiência de proteínas. Verifique se os alimentos ingeridos nas últimas 48 horas contêm a quantidade de proteínas necessária ao seu organismo (Correio da Manhã, 18 de setembro de 1959);

- A gordura é proveniente de um desequilíbrio entre os processos internos de anabolismo e de catabolismo. Isto é doença minha senhora (Correio da Manhã, 23 de setembro de 1959);

- O leite contém cálcio, como vocês sabem, principalmente o leite azedo, como o yogurt ou o soro de leite. A vitamina D é encontrada no melado e é calmante (Correio da Manhã, 30 de setembro de 1959);

- 120 gramas de espinafre cozido dão ao corpo 17 calorias. Como o processo de digestão custa ao corpo 35 calorias, comendo espinafre você sofre uma perda de caloria da gordura acumulada em seu corpo. Esses alimentos que provocam perda de gordura do corpo são chamados catabólicos. É importante, se você quer emagrecer, procurar aumentar o número de alimentos catabólicos em seu cardápio (Correio da Manhã, 29 de abril de 1960);

- Não é só o seu estomago que precisa ser alimentado. Sua cutis também tem fome e sede (Correio da Manhã, 6 de julho de 1960);

- Se você é muito magra e deseja engordar um pouco, procure, sobretudo relaxar o corpo e em seguida pensar nos alimentos que deve ingerir. Os alimentos que contém cálcio e vitamina D são muito valiosos para ajudá-la a relaxar o corpo e aprender a descansar (Correio da Manhã, 5 de agosto de 1960); 
- A pele é um órgão respiratório, tão importante como os pulmões. Assim, é imprescindível que seja mantida limpa, isto é, com os poros desimpedidos, a fim de que possa exercer a sua função de absorver o oxigênio e eliminar toxinas. A pele do rosto, sobretudo, merece cuidados especiais por ser mais delicada e, do ponto de vista estético, a mais importante do nosso corpo (Correio da Manhã, 12 de agosto de 1959);

- Todas as bebidas alcoólicas - sem exceção - fazem engordar. Para elas, não há gastos de calorias e, na digestão, constituem um combustível liquido pronto para ser armazenado sob a forma de gordura (Correio da Manhã, 17 de agosto de 1960);

- Fonte de rejuvenescimento da pele e para evitar as rugas é encontrada na vitamina B. Tome com generosidade alimentos que contenham essa vitamina especialmente o levedo de cerveja, que deve ser incluída em sua alimentação diária (Correio da Manhã, 16 de setembro de 1960);

- Faça exercícios diários para conservar a saúde. A respiração ao ar livre alguns minutos durante o dia é ótimo para ativar a circulação do sangue e para o organismo em geral (Correio da Manhã, 14 de dezembro de 1960).

Esse logos médico está também nas dicas às mães para cuidarem dos seus "filhinhos", a exemplo dos cuidados com a alimentação e primeiros socorros em caso de acidente:

- Se o seu garoto recebeu um corte pequeno, lave o local imediatamente com água e sabão e aplique uma ligadura anti-séptica, dessas que se vendem na farmácia, ou um pedaço de tecido lavado, acabado de engomar. Os anti-sépticos não devem ser fortes, não sendo indicada a tintura de iodo fresca ou álcool. Se o corte for grande, cubra-o com gaze anti-séptica apertando-a bem para deter a hemorragia e deixe ficar assim até a chegada do médico (Correio da Manhã, 22 de janeiro de1960);

- A anemia tem como causa a falta de alimentos ricos em ferro na dieta. A criança deve ingerir uma boa quantidade desses alimentos, sem o que apresentará palidez, sinais de cansaço e debilidade. Se a mãe notar que sua criança apresenta esses sintomas, mais do que qualquer xarope ou outro medicamento, importa reforça os alimentos que contêm ferro, na sua 
alimentação, como sejam o fígado, e rim de boi, a gema do ovo, nozes, avelã, trigo, frutas secas, especialmente as ameixas, os abricots, os pêssegos etc. as verduras principalmente o espinafre, o agrião e a chicória (Correio da Manhã, 11 de março de 1960);

- De todas as vitaminas, a mais importante para a criança é a vitamina A, que age sobre o crescimento do esqueleto, protege o organismo contra infecções, influi no desenvolvimento dos dentes. Além disso, descobertas recentes provam que o mecanismo coordenador que permite aos ossos do crânio e outros se adaptarem ao tamanho do cérebro e da espinha dorsal, deixa de funcionar com a deficiência da vitamina A. Os alimentos que mais contêm a preciosa vitamina são: gema de ovo, óleo de fígado de bacalhau, tomate e folhas verdes (Correio da Manhã, 17 de agosto de 1960).

Até o momento, podemos observar, nos discursos sobre o cuidado de si (beleza e saúde), o quanto o cuidado médico é traduzido por uma atenção constante com o corpo; por uma disciplina incessante em ser bela, jovem e saudável.

Nesse quadro da cultura de si, para além do que já foi observado, é fundamental que a mulher esclarecida saiba aliar sua beleza física aos atributos morais e intelectuais. Na construção dessa identidade, a mulher deve procurar mostrar sua beleza interior, adquirir autoconfiança e ter personalidade, pois, no interior dessa discursividade, alegria, otimismo e riso franco são os melhores auxiliares de beleza sem sombra de dúvida. O corpo estando impregnado por essas qualidades, obriga a mulher esclarecida a refletir sobre o seu comportamento, sobre a sua personalidade, como podemos observar nas formulações do texto abaixo:

\footnotetext{
Personalidade

Existem dois tipos de personalidade os introvertidos e os extrovertidos. O primeiro tipo é o da criatura cujos interesses estão voltados para dentro de si mesmo. Pertencem a ele, geralmente, as pessoas sem grandes responsabilidades, sonhadoras, espectadores e não participantes da vida. Os extrovertidos têm seus interesses em objetos e ações extremas, geralmente são criaturas que lutam para viver tendo outros sob sua responsabilidade, são ativas, dirigentes.
} 
O ideal é o meio termo, o equilíbrio entre o sonho e a realidade, entre a vida pratica, externa, e o profundíssimo mundo interior. Aqui estão algumas sugestões para o desenvolvimento e equilíbrio de sua personalidade:

1) - Procure variar e ampliar suas atividades. A limitação de interesses torna você própria limitada.

2) - Tome decisões, com firmeza e confiança. A indecisão é a pior coisa do mundo.

3) - Modifique as opiniões próprias quando as razões que lhe apresentaram sejam justas e convincentes. A teimosia sem fundamento é sinal de pouca inteligência.

4) - Procure rir, ser alegre. O riso faz bem à saúde e aumenta a simpatia.

5) - Não remoa as suas raivas, que isso lhe faz mal. É muito natural que sinta raiva, vez ou outra, apenas não controle, deixe-se explodir para se ver livre dela.

6) - Não cultive com exagero o amor próprio e o orgulho. A admiração e o respeito alheios não podem ser exigidos, mas devem ser conquistados.

7) - Estude, procure instruir-se, interessando-se por toda espécie de leituras.

Com essas qualidades, você será você mesma, adquirirá autoconfiança, e, para sua própria surpresa, as vitórias se tornarão muito mais fáceis. (Correio da Manhã, 2 de outubro 1960).

Construído com formas verbais imperativas, o texto exibe uma enunciação conselheira, de acordo com a prática da "literatura de autoconfiança“. Esses indícios, por sua vez, fazem ver uma representação de uma fiadora conselheira e autoconfiante cujo interesse é levar a leitora a dotar-se de tal caráter autoconfiante que lhe permitirá ser mais decidida, alegre, saudável, simpática, inteligente e, conseqüentemente, mais bonita. Entre um texto e outro estará sempre presente o tom de autoconfiança com que essa fiadora aconselha sua leitora a se comportar, como podemos observar nos títulos abaixo:

- Elegância e beleza... depois dos quarenta (Correio da Manhã, 26 de agosto1959);

- $\quad$ Compreenda o seu marido (Correio da Manhã, 4 de setembro 1959);

- Um boa esposa (Correio da Manhã, 11 de setembro 1959)

- Emagrecer... sonho de tantas! (Correio da Manhã, 23 de setembro 1959);

- Dormir bem ... e ser jovem ... (Correio da Manhã, 30 de setembro 1959);

- Você quer prolongar sua juventude (Correio da Manhã, 9 de outubro de 1959);

- Cultive a sua personalidade (Correio da Manhã, 18 de novembro 1959);

- Beleza é cuidado e perseverança (Correio da Manhã, 25 de novembro 1959);

- Cultive a sua boa aparência (Correio da Manhã, de 27 de novembro 1959);

- Valorize seus Olhos (Correio da Manhã, 4 de dezembro 1959); 
- Sedução e feminilidade (Correio da Manhã, 30 de dezembro 1959);

- Dormir para ser bela (Correio da Manhã, 8 de janeiro de 1960);

- Eduque seus filhos (Correio da Manhã, 17 de fevereiro de 1960);

- Dirigir um lar (Correio da Manhã, 24 de fevereiro de 1960);

- Ser feliz... para ser bonita (Correio da Manhã, 26 de fevereiro de 1960);

- Aprenda a respirar (Correio da Manhã, 6 de abril de 1960);

- Felicidade conjugal (Correio da Manhã, 22 de abril de 1960);

- Recursos que rejuvenescem (Correio da Manhã, 29 de abril de 1960)

- Faça você mesma (Correio da Manhã, 22 de junho de 1960);

- Seja bonita mesmo sem ir a salões de beleza (Correio da Manhã, 10 de agosto de 1960);

- Aproveite seu tempo (Correio da Manhã, 12 de agosto de 1960);

- Aproveitemos o tempo com inteligência (Correio da Manhã, 25 de setembro de 1960);

- O que os homens não gostam (Correio da Manhã, 7 de outubro de 1960).

Mas a mulher esclarecida não é apenas conselho, ela é questionamento. Ao questionar, a mulher esclarecida põe em cena como homens e mulheres estão incluídos na sociedade, ou seja, como se dá a oposição entre o corpo masculino e o corpo feminino revestidos de significação social ${ }^{29}$. Nas formulações em que esse questionamento aparece, a enunciadora mostrar ter consciência da dominação masculina (ver grifos), embora procure dar um “novo” estatuto a essa diferença social entre os gêneros, em um discurso em que as diferenças são afirmadas, enquanto as desigualdades são negadas, chegando a dizer, em alguns momentos, que ambos os sexos se equivalem:

- Serão os homens mais generosos do que as mulheres? (...) A verdade é que a generosidade real não pode ser julgada por tais aparências exteriores. O único lugar onde um julgamento desses pode ser feito é na intimidade do lar - e aí, ambos os sexos se equivalem;

\footnotetext{
${ }^{29}$ Ao falar sobre a construção social dos corpos, Bourdieu (2003: 16) diz: "a divisão social das coisas e das atividades (sexuais e outras) segundo a oposição entre o masculino e o feminino recebe sua necessidade objetiva e subjetiva de sua inserção em um sistema de oposições homólogas, alto/baixo (...) fora (público)/dentro (privado) etc. Semelhantes diferenças, tais oposições são suficientemente concordes para se sustentarem mutuamente, no jogo e pelo jogo inesgotável de transferências práticas e metáforas; e também suficientemente divergentes para conferir, a cada uma, uma espécie de espessura semântica, nascida da sobredeterminação pelas harmonias, conotações e correspondências".
} 
- As mulheres são mais inteligentes? - Porfavor, não fale alto, pois, se houver algum homem por perto, sou capaz de apanhar... Isto não é pergunta que se faça... A faculdade de inteligência foi conferida tanto ao homem como à mulher, seres racionais (...) Isto quer dizer que não há homens ou mulheres mais inteligentes. Todos têm sua cota, alta ou baixa de inteligência, e serão muito espertos se souberem aproveitá-la da melhor maneira, estudando e aperfeiçoando os dons que Deus lhe conferiu (Correio da Manhã, 6 de abril de 1960);

- São os homens mais honestos do que as mulheres? No que diz respeito à ação, em verdade, os homens são mais desonestos do que as mulheres (...) Mas em compensação, o mesmo não podemos afirmar, quando se trata de desonestidade em palavras (...) As mulheres têm muito mais facilidade de enganar aos homens do que estes a elas - é uma modalidade de compensarem a força física do sexo oposto (Correio da Manhã, de 20 julho de 1960);

- Quem é mais corajoso? O homem ou a mulher? (...) Há, portanto, uma grande diferença, na coragem do homem e da mulher. A mulher tem coragem para o sofrimento, reage vigorosamente numa desgraça, mas corre de um ratinho, enquanto que o homem, resolve problemas intricados e sai de peito aberto em noite escura, atrás de um ladrão que tentou lhe assaltar a casa, mas geme perdidamente com uma dor de cabeça banal (Correio da Manhã, 27 de julho de 1960).

Com relação à discursividade sobre o homem, objeto de desejo a ser conquistado e que deve estar ao lado da mulher esclarecida como companheiro, a coluna construir a imagem ideal desse objeto de desejo. O homem ideal construído pelo imaginário feminino esclarecido, além de ser inteligente e culto, deve ter posição social e ser atraente e cavalheiro.

Na construção desse imaginário, embora a enunciadora procure validar o discurso de que ambos os sexos se equivalem, a discursividade da coluna se mostra herdeira de uma cultura patriarcal legitimada pela relação de dominação masculina: de um lado a figura feminina fragilizada que procura agradar o homem; do outro lado, o homem viril e forte que espera ser agradado. Nessa relação de dominação, o homem, sujeito ativo, proporciona, enquanto, a mulher, sujeito passivo, é proporcionada, 
conseqüentemente, a moral feminina se inscreve através de uma disciplina incessante ${ }^{30}$ como indicam as formulações do excerto abaixo:

- Se um homem existe que merece de nós toda a simpatia, o carinho e todo o calor do nosso encanto, esse homem é o nosso marido que nos proporciona um lar, nos dá apóio nas horas de depressão, nos ajuda nas doenças, nos protege com o seu nome e a sua pessoa. Além disso, resta-nos ainda não esquecer que o fato de estar ligado a nós pela lei não o escraviza, e que outras mulheres há pelo mundo, também à procura do seu homem ideal, e que poderão desejar o nosso. Insatisfeito, sem nada receber do que se lhe deve, ele será presa fácil (Correio de Manhã, 6 de fevereiro de 1960).

Tudo isso para mostrar que: se, por um lado, podemos identificar em algumas formulações da discursividade da mulher esclarecida a constituição de posições de sujeito que indicam uma mulher reflexiva que questiona a relação de gêneros e que propõem uma reconfiguração do papel da mulher esposa, mãe e dona de casa ser reflexiva; por outro lado, podemos identificar posições de sujeito que indicam práticas que validam a inscrição de uma figura masculina controladora do comportamento feminino, isto é, que validam a inscrição de uma dominação masculina. O homem é objeto de desejo dessa mulher, pois, seja atuando no lar ou cuidando de si, a mulher tem um objetivo: agradar o homem. Nesse sentido, a mulher de Feira de utilidades se assume como sujeito e objeto esclarecido, como indicam as formulações abaixo:

- Não há dúvida de que a astúcia e dissimulação são armas autênticas femininas e as mulheres fazem uso delas para vencer o combate travado na vida, principalmente contra as outras mulheres, quando o assunto é: homem! (Correio da Manhã, 22 de janeiro de 1960);

- Outra mania prejudicial é aquela de falar alto, rir alto, esquecer quem está ao seu lado para dirigir-se ao público à volta. Esse público, geralmente, presta atenção, espantado e curioso, pensando intimamene coisas muito pouco abonadoras sobre a tagarela. Sem consciência disso, ela continua o seu "show",

\footnotetext{
${ }^{30}$ Segundo Bourdieu (2003: 38), “a moral feminina se impõe, sobretudo, através de uma disciplina incessante, relativa a todas as partes do corpo, e (...) os princípios antagônicos da identidade masculina e da feminina se inscrevem, assim, sob forma de maneiras permanentes de se servir do corpo, ou de manter a postura, que são como que a realização, ou melhor, a naturalização de uma ética”.
} 
alheia ao constrangimento do companheiro e risinho maldoso dos estranhos... os homens costumam fugir apavorados desse tipo de mulher. Os homens são, quase sempre, mais discretos e tem horror ao espalhafato (Correio feminino, 2 de março de 1960);

- Um último conselho: não tenha medo de ir, de ser você mesma. Faça o que puder para deixá-lo à vontade e satisfeito. Se conseguir isso nesse primeiro convite - o seu futuro promete (Correio da Manhã, 17 de agosto de 1960);

- É comum ouvir-se a afirmação de que os homens não gostam de mulheres inteligentes. Mas, pelo que se pode observar, são poucos os que fazem objeção à inteligência feminina (...) a mulher inteligente e culta sabe melhor compreender o homem a quem ama e aceitá-lo, não como um ser superior, mas como uma criatura feita de qualidades e defeitos... como ela própria (Correio da Manhã, 23 de novembro de 1960).

Essa ambigüidade, proporcionada por esse duplo posicionamento do sujeito, desempenha um papel importante no discursividade da mulher esclarecida. Do ponto de vista lingüístico-discursivo, ela (a ambigüidade) promove a conciliação de dois enunciados de base: de um lado, uma formulação, que valida a imagem da mulher esclarecida, A não é “ “”, A é A, sendo A ocupado pela mulher esclarecida; do outro lado, uma formulação que valida a dominação masculina $A$ ' deve fazer " $x$ ” porque $B$ espera “ $x$ ”, sendo $A$ ' ocupado pela mulher (esposa e dona de casa) e $B$ ocupado pelo homem “ideal”. É nessa tentativa de conciliar essas duas posições que se constrói a imagem da fiadora de Feira de utilidades. Mas gostaríamos de dar um estatuto privilegiado à negação que se constitui, a nosso ver, o ponto central da discursividade da mulher esclarecida, pois o enunciado negativo (A não é “ $x$ ”) propõe à mulher dos anos dourados uma “nova” retomada, um “novo” posicionamento.

\subsection{A mulher esclarecida: em “cena” a negação}

Quando Feira de utilidades visa mostrar à mulher uma nova posição sujeito, diferente da ideologia dos anos dourados, vê-se no fio do discurso uma zona de polêmica marcada na trama textual pelo uso do advérbio de negação não, pois “para constituir e preservar sua identidade no espaço discursivo, o discurso não pode haver-se com o outro como tal, mas somente com o simulacro que constrói dele" 
(MAINGUENEAU, 1984: 110). Nessa relação polêmica surge a seguinte pergunta: trata-se de uma relação polêmica que se estabelece entre dois sujeitos que representam Formações Discursivas (FDs) antagônicas ou de uma relação polêmica que afeta a interioridade da Formação Discursiva?

Para responder a essa pergunta e realizar uma análise que possibilite evidenciar o caráter constitutivamente do discurso através da relação de negação, nos filiaremos às reflexões de Frida Indursky (1990, 1997). Segundo a autora (1997: 215),

(...) quando o sujeito do discurso pode e deve dizer o que diz do seu lugar social, ele o faz por uma predicação afirmativa, identificando seu dizer com o saber da FD que o afeta. Já quando sua predicação é negativa, esta pode caracterizar três operações de negação discursiva diversas: a negação externa, que incide sobre o que não pode ser dito no interior de FD1; a negação interna, que incide sobre o que pode, mas não convém ser dito neste domínio de saber e a negação mista, que mobiliza as duas modalidades anteriores numa única operação de negação.

$\mathrm{Na}$ nossa pesquisa, nos debruçamos sobre as reflexões acerca da negação interna. Segundo Indursky, esse tipo de negação faz aparecer diferenças no interior da mesma formação discursiva, não estabelecendo fronteiras ideológicas, embora seu escopo ainda sejam enunciados pré-construídos que revelam a presença do outro. Limitamo-nos a discutir apenas a negação interna, uma vez que, no presente trabalho, as divergências observadas acontecem no interior do discurso da "mulher esclarecida". Ou seja, o discurso da “mulher esclarecida” apresenta posições de sujeito divergente daquelas defendidas pelo discurso feminino veiculado pela imprensa feminina dos anos dourados. No dizer de Indursky (1997: 229), “a negação interna trabalha sobre as diferenças subjetivas de um mesmo domínio de saber".

Mediante essa breve explanação sobre a operação da negação, associada as demais observações mostradas ao longo desse capítulo, acreditamos que, no caso do discurso da mulher esclarecida, o funcionamento discursivo da negação polêmica equivale ao que Indursky considera negação interna. Vejamos abaixo três excertos que permitirão examinar o funcionamento da negação interna. 
1) Digo-lhes que "esclarecida" é a mulher que se instrui, que procura acompanhar o ritmo da vida atual, sendo útil dentro do seu campo de ação, fazendo-se respeitar pelo seu valor próprio, que é companheira do homem e não sua escrava, que é mãe e educadora e não boneca mimada a criar outros bonequinhos mimados;

2) Você, minha leitora, não limite o seu interesse à arte de embelezar-se, de ser elegante, de atrair os olhares masculinos. A futilidade é fraqueza superada pela mulher esclarecida.

3) A mulher inteligente não é escrava dos caprichos dos costureiros, dos cabeleireiros ou dos fabricantes de cosméticos. Antes de adotar a última palavra da moda, ela estuda o efeito da mesma sobre o seu tipo. A mulher inteligente sabe que, mais importante que parecer "chique” é parecer bonita. Não quero dizer que ela ande fora de moda, use roupa e penteados antiquados.

IMPLICA EM DIZER

A mulher esclarecida não é escrava do homem

A mulher esclarecida não é boneca mimada

A mulher esclarecida não é fútil

A mulher esclarecida não é escrava da moda

A

não é " $X$ ”

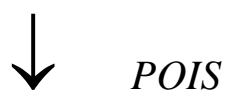

A mulher esclarecida é a mulher que se instrui

A mulher esclarecida é a mulher que estuda o seu tipo

(esclarecida)

A é $\quad A$

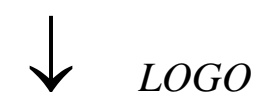

A não é "X”, Aé A

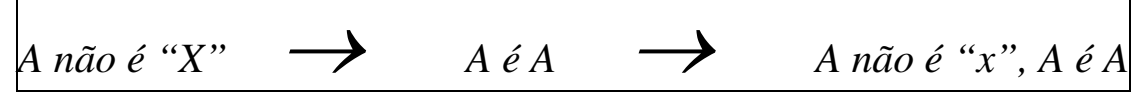


Nos três excertos, a negação incide sobre elementos de saber pertencentes à FD que afeta seus sujeitos. Dessa forma, é legítimo ser mãe, esposa e dona de casa, bem como é legitimo ser uma mulher que cuida de si, inferindo-se daí a sua feminilidade. A negação incide sobre fatos que podem ser ditos, mas que são negados, pois, é legítimo ser esposa, mas não é legitimada a esposa que é escrava do marido; é legitimo ser uma mulher elegante, mas não é legitimada a mulher que é escrava da moda, que é fútil. Ou seja, o sujeito $A$ não reconhece $X$, razão pela qual a negação incide. Nesse sentido, associado às reflexões de Indursky, observamos que a marca de negação estabelece uma oposição entre o discurso da “mulher esclarecida” e o discurso outro (da mulher escrava). Essa oposição, como podemos observar, não separa FD antagônicas, mas opõe posições de sujeito divergentes no interior da mesma FD. Nesse sentido, apontamos que identidades ideológicas não garantem posicionamentos idênticos.

Frente a esse quadro, observamos que esses fatos anunciam uma conjuntura social que sofreu transformações, acarretando mudanças no dizível dessa formação discursiva, modificando os limites do que pode ser dito, bem como do que é interditado àqueles que são por ela afetados (INDURSKY, 1997). Com isso, queremos mostrar que essa diversidade não afeta a coerência interna da formação discursiva em questão. Segundo Indursky (1997: 233),

A unidade é garantida pela identificação ideológica e a divisão é decorrente das diferentes posições de sujeito possíveis no interior de uma mesma FD. Decorre daí que a coerência de uma FD é relativa, já que contém em si espaço para a diferença e a contradição, que se instauram a partir do contraste existente entre os diversos posicionamentos possíveis no interior de um mesmo quadro ideológico. Tais posições sujeito, às vezes contraditórias entre si, devem ser entendidas como efeitos de sujeito decorrentes da conjuntura histórica.

O funcionamento discursivo de Feira de utilidades aponta as relações que a FD estabelece com a sua interioridade. Por isso, a mulher não limita seus objetivos a arranjar marido, mas quando busca o casamento como ideal, este deve seguir os padrões ditados pela moral da época, cujo saber repousa sobre a seguinte oposição agradável vs desagradável. 
Essa oposição de semas fica bem clara quando o assunto é trabalho. No dizer da coluna como um todo, o trabalho em casa é visto como agradável, enquanto o trabalho fora do lar é desagradável. Para traçar essa oposição, o argumento utilizado é a liberdade que a mulher tem ao trabalhar em casa, podendo parar a qualquer momento; já o trabalho fora prende a mulher à rotina do dia a dia do escritório ou repartições.

Na perspectiva da $A D$, sob o primado do interdiscurso, toda formação discursiva define seu domínio de saber articulando um conjunto de formulações aceitáveis (o que pode e deve ser dito) e excluindo formulações inaceitáveis a esse discurso (o que não pode e não deve ser dito). Analisando a discursividade da coluna, vejo que a mulher inserida nesse saber discursivo deve ir além dos seus afazeres domésticos, segundo a moral desse discurso, não é aceitável a imagem de mulher escrava, mas isso não implica dizer que ela deixe de cuidar dos seus afazeres domésticos, que ela vá se libertar dessa imagem de dona-de-casa.

Por isso acredito que essa discursividade passa por um processo de negação interna, pois se de um lado ela aponta uma nova posição sujeito; por outro, ela precisa negociar essa nova posição com a moral que rege a posição sujeito da mulher nos anos dourados. Ou seja, nessa negociação entre o novo e o já-dito, o novo não pode negar esse já-dito por completo, pois precisa se apoiar sobre o já-dito para se validar; na contra-mão, o já-dito não pode negar o novo, pois precisa dele para continuar acontecendo. Nessa relação entre o novo e o já-dito, mostramos a relação entre memória e discurso, pois ao se irromper sob determinadas condições de uma nova conjuntura, a produção discursiva faz circular saberes e formulações já enunciadas. 


\section{Conclusão}

O presente trabalho, estruturado em três capítulos, discutiu três questões básicas: no capítulo 1, a problemática do estatuto do gênero do discurso; no capítulo 2, o modo de genericidade da coluna feminina Feira de utilidades; no capítulo 3, a instância subjetiva do discurso da mulher esclarecida. Ao final do curso do rio, é chegada a hora de desaguar... Diria João Cabral de Melo Neto: "a um rio sempre espera um mais vasto e ancho mar”. Nesse deságüe, cabe ao analista recolher os principais vestígios deixados pelo árduo percurso de análise.

No capítulo 1, ao abordarmos a questão do gênero, procuramos, num primeiro momento, trazer as várias vozes que constituem essa problemática. O que nos motivou a construir tal quadro teórico foi o fato de que, ao contrário do título que demos gêneros discursivos: as não coincidências do dizer... uma problemática, acreditamos que as análises dos gêneros do discurso devam ser não um campo das não coincidências de dizer, mas um campo de pesquisa para onde confluem vários posicionamentos teóricos, entre eles: a lingüística textual, a pragmática, a análise do discurso, etc. Num segundo momento, trouxemos as contribuições de Bakhtin que ecoam em todos os trabalhos sobre essa problemática dos gêneros; num terceiro, tratamos os gêneros nos territórios da AD. Nesse território, exploramos as reflexões propostas por Maingueneau que têm como princípio o caráter "global" que apreende o discurso integrando o plano da enunciação ao plano do enunciado. Nesse sentido, nossa reflexão de caráter "global” se propôs a apreender a integração do plano textual com o plano discursivo, e para tal procuramos nos apoiar sobre a noção de "cena de enunciação".

No capítulo 2, tendo em vista os pressupostos teórico-metodológicos propostos por Maingueneau, demos início ao nosso percurso de análise. Partindo do princípio de que o modo de genericidade se dá na relação entre "cena genérica" e "cenografia", procuramos mostrar o funcionamento da coluna no seu campo discursivo (imprensa feminina). Num primeiro momento, colocamos em "cena” as questões ligadas, de uma certa forma, às condições de produção de Feira de utilidades, tendo sempre em vista as coerções sofridas pelos contratos que ditavam o que dizer e como dizer pelo campo discursivo (imprensa feminina) e pelo contexto sócio-histórico, que influenciavam o 
posicionamento adotado por Feira de utilidades. Num segundo momento, mostramos como se dá a legitimação enunciativa da coluna feminina na relação entre "cena genérica” e “cenografia”. Nos gêneros de caráter mais rotineiro, validavam-se os papéis tradicionais atribuídos à mulher dos anos dourados, não permitindo ao enunciador questionar o status quo. Já os gêneros de caráter mais autoral, como os "editorais, validavam a renovação do status quo por permitirem uma melhor mobilização da sua cenografia.

No capítulo 3, levando em consideração o que se apreendeu no capítulo anterior, ou seja, o funcionamento do modo de genericidade da "coluna feminina" - decidimos trabalhar com a noção de ethos para entender a instância subjetiva do discurso da mulher esclarecida. Nesse sentido, tentamos mostrar como essa identidade é legitimada no fio do discurso. Verificou-se, então, como a mulher esclarecida reforça e legitima o vínculo conjugal e as representações do corpo belo, jovem e saudável apesar de seu modo de dizer caracterizar-se por um enunciado de base marcado pela negação: $a$ (mulher) esclarecida não $e ́$ “ $x$ ”. Num efeito parafrástico, a palavra mulher equivalia ora à mãe, ora à esposa, ora à dona de casa. Assim, podemos realizar as seguintes leituras desse enunciado de base: a (mãe) esclarecida não é “ $x$ ”; a (esposa) esclarecida não é “ $x$ ”; a (dona de casa) esclarecida não é “ $x$ ”.

Terminado todo o processo de análise, vimos que Feira de utilidades carrega traços de uma cultura patriarcal, pois não busca mudar o comportamento da mulher, mas reforçar valores presentes na sociedade. Pudemos observar que Feira de utilidades não caminhou em sentido contrário à imprensa feminina da época, mas paralela a essa imprensa que validou a sua existência. Com isso, o enunciador de Feira de utilidades mantém um elo com o status quo para validar o seu dizer sobre a mulher esclarecida, pois para se constituir como uma prática discursiva da imprensa feminina dos anos dourados foi preciso estabelecer um elo com os estereótipos de mulher que a ideologia dessa época validava: mãe, esposa e dona de casa. A fim de validar e de ser validada, a cenografia desse discurso consonante com a sua cena englobante (imprensa feminina) constrói um ethos conselheiro que deixa transparecer através da estratégia do aconselhamento um caráter esclarecido que a mulher mãe, esposa e dona de casa deve incorporar ao seu modo de ser. 
(5)

\section{Referências bibliográficas}

ADAM, J.-M. (2001). Types de textes ou genres de discours? Comment classer lês textes qui disent de et comment faire? Langages, Paris: Larousse, n. 141, p 10-27, mars. université.

(1999). Linguistique textuelle: des genres de discours aux textes. Paris: Nathan

(1997). Unités rédactionnelles et genres discursifs: cadre général poru une approche de la presse écrite. In: Pratique, Metz, Suisse: [s.n], n. 94, p. 2-18, juin.

(1991). Cadre théorique d'une typologie séquentielle. Études de linguistique appliqué, Paris: Didier Érudition, n. 83, p. 7-18, juil.-sept.

AUTHIER-REVUZ, J. (2004). Entre a transparência e a opacidade. Um estudo enunciativo do sentido. Porto Alegre: EDIPUCRS.

(1998). Palavras incertas: as não-coincidências do dizer. Campinas: Editora da Unicamp.

BAKHTIN, M. (1924). O problema do conteúdo, do material e da forma na criação literária. Questões de Literatura e de Estética. A teoria do romance. 5. ed. São Paulo: Hucitec, p. 13-70. 2002.

(1929). (VOLOSHINOV, V. N.). Marxismo e filosofia da linguagem. Trad. do francês de Michel Lahud e Yara Frateschi Vieira. 9. ed. São Paulo: Hucitec, 1999.

(1929; 1963). O romance polifônico de Dostoievski e seu enfoque na crítica literária. Problemas da Poética de Dostoiévski. Trad. de Paulo Bezerra 3. ed. Rio de Janeiro: Forense Universitária, p. 3-45, 2002.

(1952-1953). Os gêneros do discurso. Estética da criação verbal. Trad. do Russo de Paulo Bezerra. São Paulo: Martins Fontes, p. 261-306, 2003.

(1959-1961). O problema do texto na lingüística, na filologia e em outras ciências humanas. Estética da criação verbal. Trad. do Russo de Paulo Bezerra. São Paulo: Martins Fontes, p. 307-355, 2003.

(1974). Metodologia das ciências humanas. Estética da criação verbal. Trad. de Paulo Bezerra. São Paulo: Martins Fontes, p. 393-410, 2003.

BARROS, D. L. P. de \& FIORIN, J. L. (orgs.) (1999). Dialogismo, polifonia, intertextualidade. 2 ed. São Paulo: Edusp.

BASSANEZI, C. (2002). Mulheres dos anos dourados. História das mulheres do Brasil. São Paulo: Fapesp, p. 607-639. 
(1992). Virando as páginas, revendo as mulheres; relações homem-mulher e revistas femininas, 1945-1964. Dissertação de Mestrado em História Social. FFLCH/USP.

BEAUVOIR, S. (1949). O segundo sexo 2. Trad. Sergio Milliet. 9 impressão. Rio de Janeiro: Editora Nova Fronteira, 1980.

BENVENISTE, E. (1995). Problemas de lingüística geral I. 4 ed. Campinas, SP: Pontes.

(1989). O aparelho formal da enunciação. Problemas de lingüística geral II. Campinas, SP: Pontes, p. 81-90.

BOUQUET, S. (2004). Linguistique générale et linguistique des genres (introduction au numéro). Langages, Paris: Larousse, n. 153, p.3-14, mars.

BOURDIEU, Pierre. (2003). A dominação masculina. 3 ed. Rio de Janeiro: Bertrand Brasil.

BRAIT, B. (2003). O discurso sob o olhar de Bakhtin. Análise do discurso: as materialidades do sentido. 2 ed. São Carlos, SP: Ed Claraluz, p. 19-30.

(org.) (2001a). Bakhtin, dialogismo e construção de sentido. Campinas, SP: editora da UNICAMP.

(2001b). Estudos Enunciativos no Brasil: histórias e perspectivas. São Paulo: Pontes: Fapesp.

BRANDÃO, H. H. N. (2002). Introdução à análise do discurso. 8 ed. Campinas, SP: Ed da UNICAMP.

(2001). Estudos sobre o discurso. Texto apresentado ao Departamento de Letras Clássicas e Vernáculas na Área de Filologia e Língua Portuguesa da Faculdade de Filosofia, Letras e Ciências Humanas da Universidade de São Paulo para concurso de Professor Livre-Docente. p 06-56.

(1988). Subjetividade, argumentação, polifonia. A propaganda da Petrobrás. São Paulo: Ed. UNESP.

BRONCKART, J.-P. (1997). Atividade de linguagem, textos e discursos. Por um interacionismo sócio-discursivo. Trad. Anna Rachel Machado. São Paulo: educ, 2003.

BUITONI, D. S. (1980). Mulher de papel: a representação da mulher pela imprensa feminina brasileira. São Paulo: Loyola.

CHARAUDEAU, P. (2004). Visadas discursivas, gêneros situacionais e construção textual. In: MACHADO, I. L. \& MELLO, R. (orgs). Gêneros: reflexões em Análise do Discurso. Belo Horizonte: NAD/FALE/UFMG, p. 13-41. 
CHARAUDEAU, P. \& MAINGUENEAU, D. (1996). Termos-chave da análise do discurso. Trad Márcio Venício Barbosa \& Maria Emilia A. T. Lima. Belo Horizonte: Ed UFMG, 1998.

(2002). Dicionário de Análise do Discurso. Coordenação de tradução Fabiana Komesu. São Paulo: Contexto, 2004.

COURTINE, J.-J. (1981). Le discours communiste adressé aux chrétiens. Langages, v. 62, Paris: Larousse.

DUCROT, O. (1984). Esboço de uma teoria polifônica da enunciação. O dizer e o dito. Trad. Eduardo Guimarães [et al.]. Campinas, SP: Pontes, p. 161-218, 1987.

FARACO, C. A. (2003). Linguagem \& diálogo. As idéias lingüísticas do circulo de Bakhtin. Curitiba: Criar edições.

FAUSTO, B. (1998). História do Brasil. 6 ed. São Paulo: Edusp.

FIORIN, J. L. (1999). As astúcias da enunciação. São Paulo: Ática.

FOUCAULT, M. (1969). Arqueologia do saber. Trad. Luiz Felipe Baeta Neves. 6 ed. Petrópolis: Vozes, 2002a.

(1971). A ordem do discurso. Trad. Laura Fraga de Almeida Sampaio.8 ed. São Paulo: ed. Loyola, 2002b.

(1984). História da sexualidade III: o cuidado de si. Trad. Thereza da C. de Albuquerque. 7 ed. Rio de Janeiro: Graal, 2002c.

GADET, F.; HAK, T. (1990). Por uma análise automática do discurso. Uma introdução à obra de Michel Pêcheux. Campinas: Ed. UNICAMP.

GOTLIB, N. B. (1995). Clarice: uma vida que se conta. 2 ed. São Paulo: Ática

GREGOLIN, M. R. V. (2003). Sentido, sujeito e memória: com o que sonhe nossa vã autoria? Análise do discurso: as materialidades do sentido. 2 ed. São Carlos, SP: Ed Claraluz, p. 47-57.

GRILLO, S. V. C. (2004). A produção do real em gêneros do jornal impresso. São Paulo: Fapesp.

HENRY, P (1983). A ferramenta imperfeita. Trad. Maria Fausta Pereira de Castro. Campinas, Ed. Da Unicamp, 1992.

INDURSKY, F. (1990). "Polêmica e denegação: dois funcionamentos discursivos da negação”. In: Caderno de estudos lingüísticos. Campinas, (19): 117-122, jul./dez.

(1997). A fala dos quartéis e as outras vozes. São Paulo: Editora da Universidade de Campinas. 
JAKOBSON, R. (1969). Lingüística e comunicação. 20 ed. São Paulo: Cultrix.

KOCH, I. V. (2002). Desvendando os segredos do texto. São Paulo: Cortez.

MAINGUENEAU, D. (2005). Gênese dos discursos. Trad Sírio Possenti. Curitiba: Criar edições. Título original: Génèses du discours, 1984.

(2004). "Diversidade dos gêneros de discurso”. In: MACHADO, I. L. \& MELLO, R. (orgs.). Gêneros: reflexões em Análise do Discurso. Belo Horizonte: NAD/FALE/UFMG, p. 43-57.

(1999b). L'analyse des discours constituants. In: MARI, H. et al. (org). Fundamentos e Dimensão de Análise do Discurso. Belo Horizonte: Carol BorgesNúcleo de Análise do Discurso. Fale-UFMG.

(1999a). "Ethos, scénografie, incorporation”. In: AMOSSY, Ruth. Images de soi dans le discours. La construction de l'éthos. Lausanne: Delachaux et Niestlé, p. 75100.

(1998). Análise dos textos de comunicação. Trad. Cecília P. de Souza-e-Silva \& Décio Rocha. São Paulo: Cortez, 2001.

(1995). Présentation. Langages. Paris: Larousse, n. 117, p. 5-11, mars.

(1993). O contexto da obra literária. Trad. Marina Appenzeller. São Paulo: Martins Fontes, 1995.

(1991). L'analyse du discours. Paris: Harchette.

(1990). Pragmática para o discurso literário. Trad. Marina Appenzeller. São Paulo: Martins Fontes, 1996.

(1987). Novas tendências em análise do discurso. Trad. Freda Indursky. 3.ed. Campinas: Pontes, 1997.

MALDIDIER, D. (1990). A inquietação do discurso - (re)ler Michel Pêcheux hoje. Trad. Eni P. Orlandi. Campinas: Pontes, 2003.

MARCUSCHI, L. A. (2003). A questão do suporte dos gêneros textuais. UFPE/CNPq. Digitado. 18p.

NEVES, M. H. M. (1999). Gramática de usos do português. 2 ed. São Paulo: Unesp.

NUNES, A. M. (1997). Páginas femininas de Clarice Lispector. Tese de doutorado, Departamento de Letras Clássicas e Vernáculas da Faculdade de Filosofia, Letras e Ciências Humanas. Pós-graduação em Literatura Brasileira, orientadora: Prof ${ }^{a}$ Dra Nádia Battella Gotlib. Universidade de São Paulo.

ORLANDI, E. P. (1983). A linguagem e seu funcionamento. São Paulo: Ed. Brasiliense. 
PAZ, G. B. (1999). El discurso periodístico. Los géneros periodísticos hacia el nuevo milenio. México: Trillas Editorial.

PECHEUX, M. \& FUCHS, C. (1975). A propósito da análise automática do discurso: atualização e perspectivas. GADET, F.; HAK, T. (1990). Por uma análise automática do discurso. Uma introdução à obra de Michel Pêcheux. Campinas: Ed. UNICAMP, p.163-252.

PÊCHEUX, M (1975). Semântica e discurso. Trad. Eni Pulcinelli Orlandi [et al.]. 3 ed. Campinas: Editora da Unicamp, 1997.

(1969). Análise automática do discurso. In: GADET, F.; HAK, T. (1990). Por uma análise automática do discurso. Uma introdução à obra de Michel Pêcheux. Campinas: Ed. UNICAMP, p. 61-161.

(1983). A análise do discurso: três épocas. GADET, F.; HAK, T. (1990). Por uma análise automática do discurso. Uma introdução à obra de Michel Pêcheux. Campinas: Ed. UNICAMP, p. 311-319.

POSSENTI, S. (2004). Teoria do discurso: um caso de múltiplas rupturasi. In: Mussalim, F. \& Bentes A. C. Introdução à Lingüística 3 - Fundamentos Epistemológicos. São Paulo: Cortez, p. 353-392.

(2003). Observações esparsas sobre discurso e texto. Cad. Est. Ling. Campinas, (44): 211-222, Jan./Jun.

(2002). Os limites do discurso. Curitiba: Criar edições.

SILVA, M. C. F. (2003). Os discursos do cuidado de si e da sexualidade em Claudia, Nova e Playboy. Tese apresentada à banca examinadora do Departamento de Lingüística do Instituto de Estudos da Linguagem da Universidade de Campinas como requisito para obtenção do título de Doutora em Lingüística, na Área de Análise do Discurso.

SILVA, T. T. S. (2003). Identidade e diferença. A perspectiva dos estudos culturais. 2 ed. Petrópolis, RJ: Ed Vozes.

SODRÉ, N. W. (1966). A história da imprensa brasileira. Rio de Janeiro: Ed Civilização Brasileira.

SOUZA, G. T. (1999). Introdução à teoria do enunciado concreto do círculo Bakhtin/Volochinov/Medvedev. São Paulo: Humanitas.

TODOROV, T. (1981). Mikhail Bakhtin: le príncipe dialogique. Paris: Seuil. 